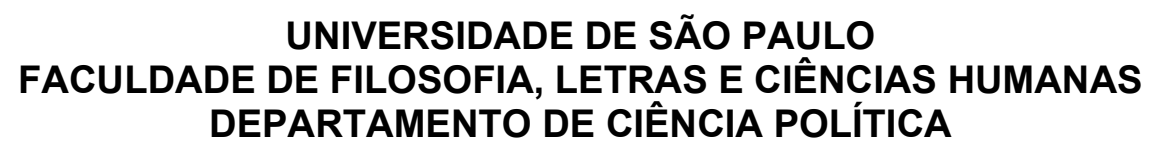

DEPARTAMENTO DE CIÊNCIA POLÍTICA

\title{
Análise dos processos penais de furto e roubo na comarca de São Paulo.
}

\author{
Ivan Borin
}

Trabalho apresentado como requisito parcial para obtenção do título de Mestre em Ciência Política, no Departamento de Ciência Política da Universidade de São Paulo.

Orientadora: Prof. Dra. Maria Tereza Sadek 


\section{Análise dos processos penais de furto e roubo na comarca de São Paulo.}

Ivan Borin

Orientadora: Prof. Dra. Maria Tereza Sadek

São Paulo

2006 
Minha amiga e platônica amada eu te faço A dedicatória neste breve sone'ato. Alexandrino são, dos versos, o formato, Embora o dissertado pro amor seja crasso!

Doce e batalhadora musa sebastiana, Distanciou-se, deixando-me grande saudade... Fui imprudente ao declarar-te minha verdade: Eu te amo, linda nativa de Americana.

Deveria estar feliz e alegre, pois neste ato, É finda a obra que me deu tamanho cansaço... Mas o destino é comigo bandido e ingrato!

Eu enamorado, choro de infelicidade... Agora que parto em uma vida cigana, Temo se torne lembrança, nossa amizade... 


\section{Agradecimentos}

Agradeço a todos que me ajudaram na elaboração desta dissertação e que cruzaram meu caminho ao longo desta jornada.

Em primeiro lugar à Maria Tereza Sadek, pela paciência e orientação ao longo desta dissertação; ao Leandro Piquet Carneiro, incentivador e colaborador em minha trajetória acadêmica; e à Maria D’Alva Gil Kinzo, primeira referência nos distantes anos da graduação.

A todos do Departamento, pela ajuda e cobranças...

Aos doutores Marcelo Sena, Marco Antônio Martins Vargas e Alex Tadeu Monteiro Zilenovski, e aos servidores Geraldo, Isaltino e Tânia, auxiliando e ensinando quando do levantamento de dados e da realização da pesquisa no Fórum da Barra Funda.

Aos amigos e familiares, por momentos bons e ruins que passamos juntos.

Aos meus pais e minha irmã, pelos valores e lições que me ensinaram, e pelo carinho e a ajuda que me deram e me dão...

À Ana Paula Barranco, grande amiga que ajudou das mais diversas formas no trabalho, nas conversas e nas lições de vida - companheira tanto nos momentos alegres quanto nos momentos difíceis...

Ao Durkhão, companheiro de todas as horas, seja nas madrugadas ou nas tardes, sempre alerta aos meus menores movimentos, reclamando sua dose diária de atenção. Despertador fiel de todas as manhãs com seu uivo irritante...

E, por fim, ao pastor Kaldi e suas cabras, lendários descobridores dos efeitos do café, sem o qual eu não conseguiria passar em claro as noites que este trabalho exigiu. 


\section{Resumo}

Esta dissertação discute três problemas dos estudos do judiciário: a discriminação de grupos sociais com impacto no tempo de sentença, nas condenações e no regime da pena; os incentivos ao recurso; e a influência de posições ideológicas dos juízes em suas decisões. Analisando os processos penais distribuídos na comarca de São Paulo em 2002, o trabalho conclui que não há padrões de discriminações por características sociais dos réus, mas sim variações decorrentes de possibilidades processuais, e uma das variáveis importantes para predizer o recurso é o regime da pena. Por fim, faz um estudo qualitativo com um pequeno grupo de juízes, que aponta uma pequena influência da posição ideológica no resultado dos processos e no incentivo ao recurso das sentenças.

Palavras chave: judiciário, sentença, recurso, discriminação, sociologia judicial, modelo atitudinal.

\section{Abstract}

This dissertation discusses three issues of judicial studies: the discrimination of social groups with an impact in the time of sentence, condemnations and disciplinary rules; stimulation to appeal; and the influence of the judge's ideological position on their decisions. Analyzing the penal processes of 2002 in the judicial districts of São Paulo, we conclude that defendants are not distinguished by their social backgrounds, but by variations resulting from processual possibilities, and one of the important variables for predicting appeals is the disciplinary rules. At last, we make a qualitative study with a small group of judges, indicating a tenuous influence of ideological position on the result of processes and the appealing of sentences.

Key words: justice, sentencing, appeal, discrimination, judicial sociology, attitudinal model 


\section{Índice}

\section{Introdução}

1 - Objetivo

\section{2 - Revisão Bibliográfica}

2.1 - Os estudos de sentença

2.2 - Os estudos sobre o processo

2.3 - O modelo atitudinal

2.3.1 - Os atores estratégicos racionais

2.3.2 - As preferências dos atores

2.3.3 - As instituições que exercem restrições às escolhas

2.3.4 - As restrições

\section{3 - Metodologia da pesquisa}

3.1 - As fontes de dados.

3.2 - Definição e construção da amostra

3.3 - A operacionalização do modelo

\section{4 - Exposição dos resultados}

4.1 - O perfil da vítima

4.2 - O perfil do réu

4.3 - O perfil dos juízes

4.4 - As características do processo

5 - Análise dos modelos

6 - Conclusão

7 - Bibliografia

8 - Legislação

9 - Anexos 


\section{Introdução}

Esta dissertação estudará os processos dos tipos penais furto e roubo distribuídos na comarca de São Paulo no ano de 2002, com o objetivo de elaborar um quadro descritivo dos autores, das vítimas, das características e resultados dos processos, procurando testar os padrões de decisão em função de variáveis sóciojurídicas, o estímulo ao recurso à segunda instância da Justiça Penal e realizar um pré-teste do modelo atitudinal, formulado pela literatura americana, com a intenção de explicar os padrões de decisão judicial.

O modelo atitudinal testará se os juízes agem de acordo com orientações ideológicas, e qual a repercussão desta orientação para o resultado do processo. Este estudo pretende contribuir para a compreensão de aspectos do poder judiciário e dos seus padrões de decisões.

O estudo do Poder Judiciário é importante não só no enfoque institucionalista, abordando o funcionamento deste poder, mas também pelo impacto que ele representa no sistema democrático como um todo. Esta importância foi ressaltada pelos estudos de cultura política. O estudo de ALMOND e VERBA sobre a cultura política apontava a importância do conhecimento das orientações subjetivas dos atores para a construção de valores que orientariam as ações dos indivíduos. Estas orientações seriam cognitivas, com relação ao conhecimento do sistema, mecanismos de input e output, e papel dos indivíduos; afetiva, com relação aos sentimentos quanto ao sistema; e avaliativa, com a combinação de informações, sentimento e conhecimento do sistema político (CARNEIRO, 1997).

Esta análise culturalista, bem como as que a sucederam, foram importantes pois possibilitaram uma generalização da idéia de que orientações intersubjetivas de ação são relevantes e devem ser levadas em conta quando analisamos a relação 
entre cidadãos e comunidade política. Estas orientações associam-se intensamente aos padrões de atitudes, opiniões e orientações políticas, imprimindo-lhes continuidade no tempo, e viabilizam as instituições democráticas (MOISÉS, 1995, p. 86-87).

Segundo MOISÉS, nos processos clássicos de democratização, estes padrões se reforçam a partir da interação entre o comportamento e o funcionamento das instituições políticas, e se sedimentam com a continuidade do processo democrático. No entanto, são necessários a presença de instituições democráticas, a tolerância política e o reconhecimento da superioridade da lei para dirimir conflito como aspectos definitivos do sistema para que este processo se concretize. (1995, p. 86).

Este último aspecto do argumento de Moisés, o reconhecimento da superioridade da lei, merece especial destaque pois causa impacto na avaliação não só do poder judiciário, mas também do regime democrático. Este aspecto foi observado por CARNEIRO (1997), que ressaltou o impacto que as variáveis relativas ao funcionamento das instituições de segurança e justiça juntamente com as culturais provocam nos regimes democráticos quanto à sua legitimidade e performance.

A importância do estudo do judiciário reside no fato de ser ele o poder, juntamente com o executivo, que dá efetividade às normas gerais e abstratas criadas pelo poder legislativo, aplicando as sanções quando de sua violação. Esta atribuição coloca o judiciário como uma das principais feições do Estado para o indivíduo, e a sua percepção por parte deste gera conseqüências não só na avaliação deste poder como também na avaliação do regime democrático como um todo. 
Dentre as diferentes ramificações em que se divide o poder judiciário, a que apresenta de forma mais clara os objetos característicos do direito é o penal. Nele estão claramente definidas a norma e a punição pela sua violação. Estes elementos definidores do direito são comuns tanto a KELSEN (1998), com sua teoria do direito positivista posto pelo legislador, passando por ALF ROSS (2000), quanto na discussão de PASUKANIS (1972), um dos teóricos soviéticos do direito.

Dentre os problemas abordados pela ciência política quanto ao poder judiciário, muitos estudos concentram-se na explicação do processo de decisão judicial, mais especificamente nas motivações e incentivos aos juízes para tomarem uma dada decisão. Outros estudos procuram explicar padrões de resultados de sentença a partir de características dos réus e da organização judicial. Estas tradições são fortes, sobretudo, nos EUA.

O sistema americano de justiça baseia-se na Common Law, e dá uma importância maior à jurisprudência, enquanto o Brasil filia-se à tradição romanogermânica do Direito, e toma por base de suas decisões a lei escrita, contudo os pontos que pretendemos abordar neste estudo - a questão do processo pelo qual o juiz formula sua decisão e as variáveis sociais dos réus e das vítimas que influenciam no resultado - podem ser comparados.

O problema de construção da decisão judicial pode ser analisado pela ótica da ciência política por se tratar de uma das formas como se dá o output das decisões do Estado. Uma estrutura que não garanta um mínimo de coerência nas respostas, que para um dado estímulo A gere respostas B e C antagônicas, pode criar um componente de instabilidade no sistema que no limite pode ocasionar sua própria destruição. 
A importância da aplicação pura da lei é ressaltada por BECCARIA, um dos primeiros teóricos do direito penal moderno que defende que: "com leis penais executadas à letra cada cidadão pode calcular exatamente os inconvenientes de uma ação reprovável; e isto é útil, porque tal conhecimento poderá desviá-lo do crime" (1959, p. 40).

O estudo das características sociais dos réus e das vítimas é igualmente importante para entender se há algum padrão de decisão operando extra-legalmente neste ramo do direito, e se ele é determinante para estabelecer padrões distintos de resultados.

E por fim, o estudo do recurso à segunda instância é também importante pois este é um dos principais motivos apontados pelos operadores do direito para a crise do judiciário. Entender os estímulos que os atores têm para recorrerem e se de fato o recurso constitui um problema deste poder é importante para compreender e dar base a políticas públicas que visem solucionar este possível motivo da lentidão do judiciário. 


\section{1 - Objetivo}

Esta dissertação tem três problemas centrais a serem explicados: o primeiro, seguindo a tradição dos estudos de sentença, se os processos penais estão sendo imparciais; o segundo, quais os estímulos aos recursos à segunda instância para os atores envolvidos no processo penal; e o terceiro, derivado do modelo atitudinal, procura mensurar a importância da ideologia dos juízes na aplicação das sentenças.

A grande questão que os estudos de sentença levantam é a importância das variáveis sócio-econômicas para influenciar o resultado dos processos penais, e se por trás das sentenças existe alguma forma de discriminação. Os estudos de sentença brasileiros feitos por BORDINI (1987), por ADORNO (1989, 1994, 1995, 1998, 2002) e por LIMA (2003) sustentam que há uma discriminação no sistema de justiça penal paulista e esta discriminação repercutiria numa maior condenação de réus negros, nordestinos e de baixo status sócio-econômico. LIMA (2003) ainda acrescenta uma discriminação de gênero, com as mulheres negras sendo mais discriminadas do que os demais grupos. Partindo destes estudos elaboramos sete hipóteses iniciais para este trabalho:
A) Os réus negros são condenados em maior proporção do que os réus brancos;
B) os réus negros são condenados a penas mais duras que os réus brancos;
C) os réus nordestinos são condenados em maior proporção do que os réus das outras regiões;
D) os réus nordestinos são condenados a penas mais duras que os réus de outras regiões;
E) além da cor, o gênero seria importante para predizer o resultado. Mulheres negras tenderiam a ser condenadas em maior proporção do que qualquer outro grupo de gênero e cor;

F) os réus de baixo status sócio-econômico são condenados em maior proporção do que os réus de alto status econômico; e 
G) os réus de baixo status sócio-econômico são condenados a penas mais duras que os réus de alto status.

O segundo problema que abordaremos é quais as características dos processos penais, quais variáveis seriam importantes para predizer o recurso à segunda instância, e qual o percentual destes recursos sobre o total dos processos.

A importância de estudarmos o recurso é o fato dele ser comumente apontado como a principal justificativa para a morosidade da justiça, conforme foi constatado pela pesquisa do IDESP de 1993.

Um dos estudos realizados sobre este tema foi o de WATANABE (2001), que analisando o furto e roubo patrimonial aponta que das sentenças submetidas ao TACRIM (Tribunal de Alçada Criminal) ${ }^{1}$, foram revistas $50 \%$ das sentenças absolutórias, contra apenas $8 \%$ das sentenças condenatórias. O problema é saber o quanto estas sentenças representam do total de sentenças julgadas e qual o percentual de recursos em relação ao percentual de processos julgados na primeira instância.

A partir deste estudo, faremos uma exploração para saber quais variáveis estimulam o recurso, se são variáveis sócio-econômicas, apontadas pelos estudos de sentença, ou se tratam de variáveis processuais, ligadas a algum padrão de sentença.

Ao final testaremos se a decisão judicial sofre influência da posição ideológica (em sentido amplo) dos juízes. Este problema é derivado do modelo atitudinal americano e da discussão dos estudos de sentença, e realizaremos um pré-teste para checar se as posições ideológicas manifestas pelos juízes apontam

\footnotetext{
${ }^{1}$ A Constituição Federal de 1946, no art.124, II autorizou a criação dos Tribunais de Alçada, inferiores aos Tribunais de Justiça, e com competência para julgar recursos sobre certas matérias definidas como de sua alçada. Esta autorização permaneceu nas demais Constituições, mas eles foram paulatimente desaparecendo. Em 2004, a Emenda Constitucional $n^{\circ} 45$ extinguiu os Tribunais de Alçada restantes - São Paulo, Minas Gerais e Paraná - incorporando-os aos Tribunais de Justiça.
} 
na direção da previsibilidade do resultado processual, e quais variáveis seriam importantes para antecipar o resultado do processo e o comportamento dos demais atores envolvidos no processo de conhecimento, os advogados e promotores. 


\section{2 - Revisão Bibliográfica}

\section{1 - Os estudos de sentença}

Os estudos sobre sentença foram muito difundidos nos Estados Unidos a partir dos anos 1960 com os movimentos pelas garantias dos direitos civis e com a perspectiva do conflito. A teoria do conflito propunha que o poder judiciário também seria palco da luta de classes, e que esta luta, no âmbito da justiça penal, ocorreria através da aplicação de punições mais rigorosas aos cidadãos de baixo status econômico.

Nos anos 1970 iniciaram-se os estudos empíricos deste poder para tentar comprovar ou refutar estas teorias. Um dos marcos destes estudos foi o artigo de CHIRICOS e WALDO (1975), onde fizeram um teste empírico analisando as sentenças aplicadas a 10.488 sentenciados em 3 estados, para 17 tipos penais. Eles procuraram testar se o tempo de sentença era aplicado discriminando pessoas de baixo status sócio-econômicos, como defendia a "perspectiva do conflito", construindo uma variável sócio-econômica (SES) a partir da renda, do nível educacional e da ocupação dos sentenciados, baseado-se no censo americano.

Eles controlaram o modelo pela cor, pela primariedade do réu (se tinha outras passagens, se cumpriu pena em instituições juvenis ou se fora condenado por outros crimes graves), pela idade do acusado (menor de 25 anos) e pela característica do condado (urbano ou rural).

A hipótese que eles trabalharam foi a relação inversa entre o status econômico e o tempo de sentença, isto é, à medida que aumenta o status econômico do réu, dentro da escala formulada por eles, o tempo de sentença aplicado deve diminuir. 
Dos dezessete casos analisados, só em um a correlação foi significante e na direção da hipótese, em outros 10 casos ela é significante em sentido contrário da hipótese. Ou seja, somente em um dos casos, com 95\% de confiança, pode-se afirmar que os réus de menor status econômico tinham penas maiores, em outros 10 tipos penais os réus de maior status econômico tinham penas maiores.

A cor do réu também não interferiu no tempo de condenação. As variáveis que se revelaram mais importantes para predizer o tempo de sentença foram os antecedentes criminais e as de urbanização, embora esta última em menor proporção. Os resultados para os 13 casos são apresentados na tabela I:

Tabela I - Resultados das regressões múltiplas para diferentes tipos penais para o Estado da Flórida (Numero de casos, $\mathbf{R}^{2}$, e coeficientes Beta).

\begin{tabular}{|c|c|c|c|c|c|c|c|c|c|}
\hline Tipo & $\mathbf{N}$ & $\mathbf{R}^{2}$ & SES & $\begin{array}{c}\text { Condena } \\
\text { ção } \\
\text { anterior }\end{array}$ & $\begin{array}{c}\text { Outras } \\
\text { passage } \\
\text { ns }\end{array}$ & $\begin{array}{l}\text { Urbaniza } \\
\text { ção }\end{array}$ & $\begin{array}{c}\text { Instituiçõ } \\
\text { es } \\
\text { juvenis }\end{array}$ & Idade & Cor \\
\hline Homicídio & 64 & ,14 &, 09 &,- 07 &, 02 &,$- 24^{2}$ &, 07 & - &,- 18 \\
\hline H. Culposo & 95 & ,13 & ,06 &, $26^{3}$ &,- 11 &,$- 15^{2}$ &,$- 22^{3}$ & ,15 & ,13 \\
\hline Seqüestro & 73 &, 08 &,- 17 &,- 11 & ,14 &,- 15 &,- 02 &,- 21 &, 06 \\
\hline Agressão & 188 & ,04 &, 03 &, $15^{2}$ &,- 02 &,- 04 & - &,$- 17^{3}$ & ,06 \\
\hline Roub. Armado & 140 & ,05 &,- 02 &, $19^{2}$ &, 04 &,- 10 &, 02 &,- 03 & ,08 \\
\hline Roub. Desarm. & 270 & ,05 &,- 04 &, 09 &,- 10 &,$- 12^{3}$ & ,03 &, $16^{3}$ & ,07 \\
\hline Arrombamento & 557 &, 06 &, $09^{3}$ &, $13^{3}$ &,- 05 &,- 04 &,$- 07^{2}$ &, $13^{3}$ &,- 01 \\
\hline Furto & 225 & ,09 & ,06 &, $29^{3}$ &,- 04 &,$- 15^{3}$ &, $18^{3}$ &,- 10 &,- 02 \\
\hline Furto residência & 58 & ,11 &,- 07 &, $33^{2}$ & ,02 & ,07 & ,19 &,- 21 & ,03 \\
\hline Furto veículo & 106 & ,19 &, 09 &,- 11 &, $26^{2}$ &, $18^{2}$ &,$- 27^{3}$ & ,15 & ,07 \\
\hline Falsificação & 221 & ,06 &,- 01 &, $13^{1}$ & ,06 &,- 01 &,$- 16^{3}$ &,- 05 &,- 01 \\
\hline Drogas & 233 & ,09 &,- 07 & ,04 &, 09 &, $21^{3}$ &,- 01 &, $16^{3}$ &,- 09 \\
\hline Fuga & 88 & ,07 & 09 & ,08 &,- 19 &,- 13 &,- 02 &, $28^{1}$ &,- 04 \\
\hline
\end{tabular}

Fonte: CHIRICO e WALDO (1975)

Esta investigação gerou um grande debate. Em 1977, REASONS rebateu o estudo de CHIRICOS E WALDO (1975) afirmando que a proposição da teoria de conflito diz que a punição é mais dura para os de baixo status, que deveriam ser condenados em maior número a penas de privação de liberdade ao invés do probation, e que isto não repercutiria necessariamente no tempo de condenação. 
HOPKINS (1977) também rebate CHIRICOS E WALDO (1975) criticando o tratamento contínuo dado à variável status sócio-econômico, e que esta variável seria dicotômica na teoria, com uma categoria de baixo e outra de médio e alto status. Afirma também que esta divisão poderia demonstrar mais claramente o proposto na teoria, pois quem responderia aos crimes seriam, sobretudo, pessoas de baixo status. Quanto aos tipos penais escolhidos, estes seriam os que apresentariam maior número de pessoas de baixo status, pois as pessoas de alto status devem responder mais aos crimes de evasão de impostos, crimes ambientais, corrupção, e que estes crimes deveriam receber penas bem mais curtas que os outros tipos penais.

GREENBERG (1977) também critica o artigo argumentando que a teoria do conflito defende punições mais severas para pessoas de baixo status sócioeconômico. Outra crítica é que a variável status da vítima não foi incluída, pois para esta teoria os pobres vitimariam os próprios pobres. Outro ponto que poderia entrar em conflito era a cor do agressor e da vítima. Destaca também que no período do estudo este padrão já estava se modificando pela força adquirida pelos movimentos negros e por direitos civis, e pelo ingresso na magistratura de juízes negros. Estas características estariam refletindo nestes resultados.

CHIRICOS E WALDO (1977), respondendo a estas críticas, sustentam que a análise dos réus com $10 \%$ dos mais alto status com relação aos $10 \%$ de mais baixo não mostrou diferenças significativas.

Estes estudos continuaram pelas décadas seguintes. Em 1981, THOMSON e ZINGRAFF analisam as respostas que diferentes artigos chegaram para o problema da discriminação de cor e de status econômico, e fazem uma síntese dos principais problemas que eles viam nestas conclusões. 
O primeiro problema é que alguns estudos foram feitos em longo intervalos de tempo, abrangendo contextos sociais e políticos distintos. O segundo é que estes estudos agregaram dados de diferentes juízes, e a discriminação poderia ocorrer em alguns juízes apenas. O terceiro é que estes estudos não atentaram para a diferença de punição, concentrando-se na maior parte das vezes no tempo da sentença. O quarto diz respeito à cor e ao status da vítima serem ou não iguais ao do agressor.

As três últimas críticas podem ser feitas ao artigo de CHIRICO E WALDO (1975), que trabalham com dados agregados, procuram explicar o tempo de sentença e não consideram as características da vítima. No entanto, na nossa opinião, a crítica a agregação de dados sem discriminar juízes não seria cabível, pois a preocupação de todos os estudos é medir se o sistema como um todo está promovendo um julgamento com variáveis extraprocessuais, e se por ventura algum caso dentro destes apresentar discriminação, pode ser um desvio isolado que não invalida o comportamento sistêmico.

Analisando a sentença de roubo armado para três anos (1969, 1973 e 1977), THOMSON e ZINGRAFF (1981) concluem que no último ano, as variáveis cor e punição anterior eram significantes para explicar variação no tempo de sentença, e que não-brancos tendiam a ter sentenças moderadas, enquanto brancos tendiam a receber sentenças brandas. No caso de punições anteriores as penas eram mais duras para ambos os grupos.

Nos outros anos eles argumentam que a maioria dos casos eram intraclasses e isto, de certa forma, dificultaria a identificação da discriminação. Argumentam ainda que os juízes condenavam em igual proporção brancos e negros 
à privação de liberdade, o que não ocorria anteriormente, quando havia maior condenação ao probation de indivíduos brancos.

Os estudos da década de 1980 em diante incorporam muitas destas críticas e passam a tratar o problema a ser explicado de duas maneiras diferentes: quanto ao tempo de condenação e quanto ao rigor da condenação. Em 1987, MYERS E TALARICO publicam um artigo que analisa 27.720 condenações no período de 1976 a 1985, no Estado da Geórgia, e concluem que a cor, o sexo e a gravidade do delito seriam variáveis importantes para prever a variação na condenação à privação de liberdade ou ao probation, mas não seriam importantes para prever o tempo de prisão. A única variável que seria significativa para tempo de prisão seria a urbanização. No caso de crimes violentos, os juízes de regiões urbanas tendem a condenar em igual proporção, só que com penas menores do que nas zonas rurais.

Na década de 1990, DIXON (1995) incorpora a esta discussão, além destas variáveis sócio-econômicas, outras abordagens para o estudo das sentenças: a teoria legal; a política e a organizacional, e testa as hipóteses analisando 73 condados do Estado de Minnesota. Ele conclui dando especial destaque a uma variável proposta pela teoria organizacional, a barganha política entre as elites jurídicas para que as sentenças sejam fixadas em termos mínimos. Esta variável desempenharia um papel importante nas cortes altamente burocratizadas enquanto nas de baixa burocratização os argumentos legais seriam mais importantes, já as variáveis cor e status social teriam pouca importância. Ele faz uma ressalva afirmando que no Estado estudado a população branca é bem maior que a negra, o que poderia estar influindo no comportamento da variável cor.

Em 1999, STTEFENSMEIER incorpora as características do juiz para explicar a variação. Ele analisou se o gênero do juiz é uma variável que interfere na 
sentença, comparando se há diferença nos elementos levados em conta na decisão, e controlou pelo contexto organizacional, experiência e características do caso. Ele estudou os casos do estado da Pensilvânia entre 1993 e 1995, comparando as sentenças de encarceramento e o tempo de sentença.

Partindo de estudos que alegam que mulheres e homens teriam processos de sociabilidade diferentes, ele construiu a hipótese de que as mulheres, sendo menos expostas a situações de risco, tenderiam a julgar com mais rigor e com padrões morais, enquanto os homens fariam julgamentos mais técnicos. Esta diferença provocaria impacto na população reincidente pois como esta população é predominante de negros jovens, este grupo seria julgado com maior rigor. Outro ponto é que esta diferença deveria se manifestar em crimes contra o patrimônio, nos quais o juiz gozaria de maior liberdade para aplicar a sentença.

As conclusões revelam que as mulheres encarceram $10 \%$ mais e dão sentenças em média seis meses mais longas. Esta diferença aparece nos crimes de baixa gravidade; os crimes sexuais e violentos são duramente reprimidos por ambos os gêneros.

As mulheres também seriam mais rigorosas com réus negros jovens, e a idade do juiz também teria impacto na sentença, sendo os juízes velhos mais rigorosos. Os réus sofreriam discriminação ao longo de um contínuo: saindo de réus negros jovens, réus brancos jovens, até rés brancas idosas e por último, rés negras idosas.

Em 2000, STTEFENSMEIER incorpora outra variável ao debate, a origem étnica do réu. Usando dados coletados das cortes federais entre os anos de 1993 e 1996, ele testa se a cor e o grupo étnico interferem na condenação. Os resultados apontam a variável étnica como a de maior impacto na variação, com réus hispanos 
recebendo penas mais duras do que réus brancos e do que réus negros, e recebendo penas mais longas.

No Brasil estes estudos começam a ser feitos a partir dos anos 1980. As variáveis apontadas como responsáveis por discriminações ao longo do processo são a migração, a cor e o gênero.

O primeiro estudo que citamos é o de BORDINI (1987), defendendo que a migração orientava o olhar da repressão policial, que em maior medida puniria os grupos que aparentavam ser migrantes, mas que esta variável não deveria ser tomada como uma variável importante da criminalidade.

A migração teria outro efeito: os indivíduos deste grupo receberiam salários menores e estariam sujeitos a estratos sócio-econômicos mais baixos de socialização. Estes estratos estariam sujeitos a uma maior repressão policial, o que repercutiria numa maior taxa de delinqüência deste grupo. Esta taxa seria decorrente não do fato deste grupo cometer mais crimes, mas por estarem sujeito a uma vigilância maior. No entanto, a parte empírica apresenta poucos dados para confirmar esta suposição.

No final da década de 1980 e ao longo da década de 1990 ADORNO se dedica a estes estudos numa série longa de artigos que giram em torno da afirmação que a população negra e parda sofreria maior discriminação no aparelho de repressão policial e na justiça penal, e que a população pobre sofreria uma vigilância maior.

Em 1989 ADORNO faz um mapeamento dos estudos daquele momento e defende que uma linha apontava na direção de um aumento dos crimes patrimoniais em diminuição aos crimes de sangue, e defendia que uma das causas era a diminuição do fenômeno da migração. Outro ponto que ele destaca é que a 
população migrante e a população negra sofreriam uma vigilância maior por parte da polícia e dentro das prisões, seriam vistas como desocupadas, mas na verdade esta divisão espelharia a composição da população paulistana, entretanto não são apresentados dados para sustentar estas hipóteses e proposições.

Em 1994 ADORNO aponta que ao longo dos anos 1980 a criminalidade sofre um boom que se repercute no sistema de justiça. Este aumento leva a uma seletividade maior dos processos, restringindo a punição àqueles vistos como mais graves, como roubo, tráfico e homicídio. Outro ponto que ele critica é a mudança da legislação de 1984 para um sistema que procura diferenciar presos, com a solução alternativa de punições, e que não estaria sendo implementada. Ele também defende a idéia que o sistema de justiça puniria em maior proporção negros e pobres e que, embora a legislação seja liberal, o tratamento organizacional continuava sendo autoritário sobretudo para este grupo.

Em 1995 ADORNO sustenta a existência de uma discriminação por parte da justiça criminal paulista. Seu argumento é o de que réus negros seriam mais discriminados do que réus brancos em uma idêntica situação. Ele procura as causas deste tratamento diferenciado e como se materializa a distribuição desigual dos direitos e do acesso à justiça (p.49).

Com base nos processos julgados em primeira instância na Comarca de São Paulo em 1990, e partindo da proporção da população branca e negra da cidade, para o ano de 1980, ADORNO (1995) tenta estabelecer uma proporção de processos para negros e brancos que obedeçam a esta mesma distribuição. A classificação das penas foi feita com base no mesmo tipo penal, e a comparação da cor com os registros em três momentos do processo: Boletim de Ocorrência, 
Inquérito e Processo Penal. Dentre as etapas levantadas, destacamos o desfecho processual, ilustrado na tabela II (p. 59).

Tabela II - Desfecho processual em função da cor (em \%)

\begin{tabular}{lcc}
\hline Desfecho & Brancos & Negros \\
\hline Absolvição & 37,5 & 31,2 \\
Condenação & 59,4 & 68,8 \\
Extinção da Punibilidade & 3,1 & \\
\hline & $\mathbf{1 0 0}$ & $\mathbf{1 0 0}$ \\
\hline
\end{tabular}

Fonte: ADORNO (1995, p.59)

A conclusão de ADORNO (1995) é que não há diferenças entre réus negros e brancos quanto ao "potencial" para o crime violento, no entanto eles sofreriam maior perseguição penal, maior obstáculo no acesso à justiça, maior dificuldade de usufruir do direito de ampla defesa e maior probabilidade de serem punidos.

A metodologia deste estudo apresenta um problema grave porque trabalha com universos diferentes e tempos distintos, muito distantes. O problema mais grave desta abordagem é considerar que o universo da população seja o mesmo do de pessoas que respondem a processo penal. Só poderíamos falar em discriminação no sistema de justiça se observássemos uma tendência de ingressantes que respondem por delitos similares terem resultados díspares no final do processo.

Em 1998 ADORNO analisa o processo de transição democrática e aponta algumas influências para o que ele chama de aumento das práticas violentas e arbitrárias do Estado. Ele destaca uma mudança no padrão de criminalidade com aumento dos crimes violentos, sem correspondente elevação do número de inquéritos e processos penais instalados, e também uma queda no número de condenações nestes processos.

Em outro artigo de 1998, ADORNO $\left(1998^{\mathrm{b}}\right)$ refere-se a um aumento generalizado das taxas de crimes violentos no mundo. No caso brasileiro, este 
aumento é acompanhado por uma alteração no perfil do criminoso, constituindo uma nova modalidade - o crime organizado - e o surgimento de novas modalidades de crimes contra direitos humanos praticados por agentes do Estado e por civis através de linchamentos.

Este quadro encontra uma estrutura rígida e velha da Justiça que passaria a exigir um maior grau de formalismo para segurar o fluxo de processos que chegam até ela, e que não poderiam ser solucionados pela legislação vigente.

Isto levaria a um quadro de impunidade penal, sobretudo para crimes de pequena criminalidade, que deixariam de ser investigados. Mesmo os crimes violentos estariam sujeitos a uma "área de exclusão penal" e só seriam investigados se sujeitos a pressões externas.

A sanção penal, no entanto, seria aplicada com maior rigor a cidadãos negros, migrantes, e desempregados, deixando de ser aplicada a cidadãos de classe média e alta. Analisando as condenações do júri, ADORNO (1998b) aponta que $68 \%$ dos réus negros são condenados, contra $59 \%$ dos brancos.

Aqui temos um problema de atribuição ao poder judiciário de algo que está fora de seu controle. A decisão pela condenação nos casos de crime contra a vida não é do juiz, mas do júri. O juiz apenas formula as questões feitas ao júri e depois aplica a pena de acordo com a convicção que o júri manifestou para o caso.

Outras falhas que ele aponta são a demora entre o tempo do registro policial e o tempo para a sentença, falhas na coleta de provas, e outras referentes à qualidade dos profissionais que atuam nesta área.

Em 2002 ADORNO chama a atenção para uma crise no sistema de justiça penal e que sua face visível seria a impunidade. Ele diz que a punição é dirigida a grupos negros e migrantes e atinge pouco os cidadãos das classes altas da 
sociedade. A taxa de impunidade seria alta para os crimes de pequena criminalidade que não chegam a ser investigados, e roubos, homicídios e tráfico de drogas comporiam a área de exclusão penal, bem como para colarinho branco. Para os crimes contra o patrimônio a chance de ser condenado caiu de 5,06\% para 4,22\%. Esta descrença, segundo o autor, levaria a um esvaziamento da Justiça Penal e a busca de proteção privada e apelação para uma justiça particular.

Tabela III - Taxa de condenação em relação aos crimes registrados (em \%)

\begin{tabular}{lcc}
\hline Desfecho & \multicolumn{2}{c}{ Anos } \\
& 1970 & 1982 \\
\hline Processadas & 75 & 65 \\
Condenação & 27 & 22 \\
Absolvição & 48 & 43 \\
\hline
\end{tabular}

Fonte: ADORNO (2002)

Esta relação entre cor e punição aparece como o principal problema levantado pelos estudos nacionais, com algumas pequenas incorporações. Outro estudo que segue neste sentido, defendendo uma relação entre cor e punição, é o de LIMA (2003). Baseando-se no percentual de indiciados por gênero e cor e no total de sentenciados e sentenciados com execução, também conclui haver uma discriminação por parte do sistema de justiça, sustentando que as mulheres negras são as que mais sofrem discriminação ao longo deste processo. Os dados mais importantes estão descritos na tabela IV.

Tabela IV - Distribuição das fases do processo por cor e gênero em relação ao total do gênero

\begin{tabular}{cc|ccc|ccc|c}
\hline \multirow{2}{*}{ Gênero } & Cor & \multicolumn{3}{|c|}{ Indiciados } & \multicolumn{3}{c|}{ Sentenciados } & Execução \\
& & flagrante & Portaria & Total & Conden. & Absolvido & Total & \\
\hline \multirow{2}{*}{ Homens } & Brancos & 52,95 & 57,72 & $\mathbf{5 5 , 1 6}$ & 53,61 & 57,46 & $\mathbf{5 3 , 9 9}$ & 52,46 \\
& Negros & 45,95 & 40,78 & $\mathbf{4 3 , 5 6}$ & 45,24 & 41,40 & $\mathbf{4 4 , 8 6}$ & 46,66 \\
\hline \multirow{2}{*}{ Mulheres } & Brancos & 51,83 & 61,63 & $\mathbf{5 5 , 9 5}$ & 51,67 & 60,47 & $\mathbf{5 2 , 8 4}$ & 49,46 \\
& Negros & 46,63 & 36,29 & $\mathbf{4 2 , 2 8}$ & 47,15 & 38,21 & $\mathbf{4 5 , 9 7}$ & 49,77 \\
\hline
\end{tabular}

Fonte: LIMA (2003, p. 2) 
Esta interpretação, em nossa opinião, apresenta um problema grave. Ele considera os dados agrupados, quando se sabe que as cores e gêneros têm proporções diferentes de indiciamento por flagrante e por portaria. $\mathrm{O}$ fato de um réu ser indiciado por flagrante delito aumenta a chance de condenação. Segundo TOURINHO $\left(2000^{\mathrm{a}}\right.$, p. 268) o flagrante delito ocorre quando o indivíduo está cometendo a infração; acaba de cometê-la; é perseguido fazendo presumir ser autor da infração; ou é encontrado logo depois com instrumentos, armas, objetos ou papéis que façam presumir ser ele o autor da infração. Neste caso, a probabilidade de conseguir provas, testemunhas ou outras formas processuais válidas para se chegar à culpabilidade do autor aumenta. E, no caso dos dados apresentados, o grupo que apresenta maior ocorrência de prisão em flagrante é entre os indivíduos da cor negra.

Um segundo ponto importante é que ele não dá destaque para o percentual que cada grupo representa no total de condenados. Conforme será apresentado adiante, no caso das informações do banco de dados utilizado neste trabalho, os réus homens respondem por $96,8 \%$ dos casos de roubo.

Fazendo um mapeamento das posições deste debate, teríamos um consenso que o tempo de punição não é influenciado pelas características do réu no sentido que a teoria prevê, com os estudos empíricos apontando para uma igualdade nas punições, ou até mesmo para uma punição mais longa para a população branca. O debate americano migrou mais para o rigor da punição do que propriamente o tempo da sentença. Neste ponto há divergência quanto ao efeito da cor, e surgem outros estudos que apontam a origem étnica como mais importante para esta discriminação. No caso do Brasil, os estudos defendem uma discriminação 
de cor e de etnia, e também a influência do gênero do réu para o resultado do processo.

\section{2 - Os estudos de processo}

O segundo debate que abordaremos, com um enfoque mais exploratório, é o das características dos processos penais de furto e roubo, e quais os efeitos do recurso sobre ele. Estudar o recurso é importante, pois ele é visto como um dos principais problemas que o poder judiciário precisa enfrentar para superar a crise pela qual passa.

Partindo da pesquisa que o IDESP promoveu em 1993 junto a 570 juízes do Brasil para ver a percepção destes quanto à chamada "Crise do Judiciário", o recurso foi apontado como o principal problema para $73 \%$ dos juízes entrevistados. (SADEK, 1995 ${ }^{\mathrm{b}}, \mathrm{p}$ 19).

Mais especificamente quanto ao recurso penal, em 2000 o CEBEPEJ elaborou uma pesquisa sobre os processos dos tipos penais furto e roubo que deram entrada no Tribunal de Alçada Criminal (TACRIM) no período de 1991 a 1999. Este estudo tinha por objetivo revelar o perfil do réu nos delitos contra o patrimônio e apontou que no período de 1991 à 1999 deram entrada no TACRIM 57.997 feitos, dos quais 17.220 eram de furtos e 40.777 de roubos (WATANABE, 2001, p.3), com uma média de 5.097 recursos de roubo por ano. Este mesmo estudo também apontou que, das sentenças absolutórias recorridas, metade delas foi reformada, enquanto que o percentual de condenações foi reformado em apenas $8 \%$ dos casos.

Uma das pesquisas mais recentes sobre este problema foi realizada pelo IBCCRIM (2005), mas acentuou mais as características sobre o processo sem entrar 
em modelos explicativos. Ela traça um retrato do funcionamento da Justiça e propõe duas hipóteses: a maioria dos indivíduos condenados, ainda que primários e obtendo a reprimenda no mínimo legal, obtém uma condenação no regime mais gravoso; e motivações extrajudiciais estariam afetando as decisões.

No entanto, do nosso ponto de vista, esta pesquisa apresenta um problema grave no seu desenho metodológico que limita as suas conclusões. O universo é o dos processos em que houve apelação ao Tribunal de Alçada, logo, a seleção dos casos pode ser tendenciosa, gerando uma distorção quando generalizada para a Justiça como um todo. Os resultados devem ser vistos como indicativos apenas da Justiça de segunda instância.

Segundo esta pesquisa, o grande problema destes processos é a tendência dos juízes decidirem pelo regime fechado.

Tabela V - Regime condenatório - Estado de São Paulo (1999-2000)

\begin{tabular}{lcc}
\hline \multicolumn{1}{c}{ Regime } & \% das Sentenças & \% dos acórdãos \\
\hline Fechado & 77,19 & 66,94 \\
Semi-aberto & 14,71 & 20,50 \\
Aberto - sursis & - & - \\
Aberto - Pena restritiva & - & - \\
Não informado & - & - \\
\hline Fonte: IBCCRIM (2005, p.24-25) & &
\end{tabular}

A diferença entre os acórdãos e as sentenças está concentrada, sobretudo, nos casos em que a primeira instância define o regime como fechado e o Tribunal reforma para o semi-aberto.

Tabela VI - Pena base fixada - Estado de São Paulo (1999-2000)

\begin{tabular}{lcc}
\hline Pena base no mínimo legal & \% das Sentenças & \% dos acórdãos \\
\hline Sim & 77,19 & 81,82 \\
Não & 19,67 & 11,74 \\
\hline
\end{tabular}

Fonte: IBCCRIM (2005, p.28-29) 
Nota-se também uma diferença quanto ao sujeito que propõe a apelação. No caso há um grande predomínio dos recursos interpostos pelo réu em $77 \%$ dos casos.

Tabela VII - Apelação - Estado de São Paulo (1999-2000)

\begin{tabular}{lc}
\hline \multicolumn{1}{c}{ Apelação } & $\%$ \\
\hline Réu & 77,02 \\
Ministério Público & 10,58 \\
Ambos & 11,90 \\
Não informado & - \\
\hline Fonte: IBCCRIM (2005, p.34) &
\end{tabular}

Este trabalho também fez um levantamento de argumentações presentes nas sentenças e chega à conclusão de que o fundamento das decisões é dado por questões de caráter extra-jurídico, e que os condenados obtêm condenações mais gravosas que as previstas em lei.

Por este último estudo temos um ponto de partida da exploração que o regime da pena deve ser uma variável importante para predizer o recurso, visto ser este o aspecto que apresenta maior variação em relação à primeira instância.

Outro ponto é que embora o percentual de reforma de decisões apontado por WATANABE (2001) seja alto para as sentenças absolutórias, estas sentenças, segundo o estudo do IBCCRIM, seriam no máximo $10,58 \%$ dos processos recorridos, uma vez que este é um recurso que só o Ministério Público pode propor. Este percentual é ainda menor, pois o Ministério Público também recorre das condenações, e este outro tipo de recurso está incluído nesta porcentagem.

Embora estudem tempos diferentes, pois o período analisado pela pesquisa do CEBEPEJ é muito mais amplo, a ordem de grandeza deve se manter pois não houve nenhuma grande alteração processual no período entre as duas pesquisas 
que pudesse justificar uma mudança neste padrão, e os atores envolvidos são praticamente os mesmos. Esta comparação, no entanto, não é conclusiva.

\section{3 - O modelo atitudinal}

A terceira discussão que abordaremos nesta dissertação é referente à conduta dos juízes dentro do processo e foi formulada, entre outras propostas de explicação, pelos autores do modelo atitudinal. Este modelo tem como um de seus principais autores SEGAL (2002, p. 87-89), e procura os valores e atitudes ideológicas dos juízes que estariam por trás das decisões. Este modelo surge no interior do movimento do realismo legal dos anos 1920, de LLEWELLIN e FRANK, que buscava combater a jurisprudência formalista e conservadora. Posteriormente, foi influenciado pelos behaviouristas com o objetivo de testar cientificamente as teorias políticas.

Este modelo possui duas vertentes, uma psicológica, que procura a motivação dos atores em uma escala ideológica, e outra econômica, ligada às vertentes da escolha racional (SEGAL, 2002, p. 90-92). No caso da vertente econômica, seria difícil pensar numa motivação econômica aos indivíduos neste ramo específico da justiça.

A teoria de escolha racional pressupõe que se evidenciem os mecanismos de causa que levam aos resultados observados num dado fenômeno, a base desta teoria é o indivíduo. Segundo ELSTER (1989), a vida social parte da ação humana. Do indivíduo deve partir qualquer explicação, e pode-se chegar até às organizações mais complexas.

As premissas deste modelo são: os indivíduos são racionais e têm razão instrumental; têm preferências e maximizam suas utilidades de forma a obter aquilo 
que mais desejam. Por conta disto, ao escolherem o curso de sua ação eles escolhem a mais favorável. No entanto estas escolhas sofrem restrições físicas, econômicas, legais, psicológicas, etc. Segundo ELSTER (1989), o conjunto de oportunidades definido por estas preferências e restrições constituiria o primeiro filtro.

O problema é saber quais são as preferências dos indivíduos, pois elas são internas e o máximo que podemos observar são suas realizações. Por outro lado as restrições são objetivas e fáceis de se observar.

Ao tomarmos por base esta teoria para explicar nosso problema temos que identificar quem são os atores estratégicos racionais, quais são as suas preferências, quais são as instituições que exercem restrições a estas preferências e como esta restrição é exercida.

\subsection{1 - Os atores estratégicos racionais}

Os juízes de primeira instância são os atores racionais principais, mas não são os únicos atores estratégicos que devem ser contemplados no processo. Eles são atores, mas não têm a iniciativa, pois apenas reagem; os atores ativos são os promotores de justiça e os advogados. O problema é como estudar estes atores pois só conhecemos o resultado de suas ações, enquanto o juiz está obrigado a justificar suas escolhas. Para identificar os atores estratégicos racionais temos que retomar os atores que, segundo o processo penal, podem atuar na lide.

O processo penal e o processo em geral são organizados em uma estrutura trina com três sujeitos principais: o Estado, o demandante e o demandado. Esta estrutura é hierárquica, com o Estado no vértice mais alto da relação, impondo sua jurisdição sobre os demais sujeitos (CINTRA, 1993, p.43). 
A Justiça Penal tem o Estado em duas das suas posições. Para os tipos penais que estamos estudando, o Estado ocupa a posição de autor, exercendo o ius puniende, a pretensão de punir, através do promotor de justiça, juntamente com a posição de declarador do direito assumida pelo juiz, que, através das leis processuais, regula o poder punitivo do Estado. Representando a outra parte, e procurando garantir o direito de liberdade do autor da conduta penal, aparece o advogado (TOURINHO FILHO, 2000ª , p.14-15).

Estes são os três atores que aparecem no momento do processo de conhecimento, mas antes desta etapa deve ocorrer o fato infringente para que se estabeleça a relação jurídica. Esta primeira etapa envolve a vítima e o autor do crime, e no outro vértice, o Estado, que pode desempenhar dois papéis: de guardião e repressor. Cabe uma digressão para os estudos sobre a criminalidade.

COHEN (1979) usa esta imagem trina para ilustrar as possibilidades do crime, onde o Estado desempenharia dois papéis em um mesmo vértice do triângulo de causas da criminalidade: as funções de vigia e de repressor, dificultando e desestimulando a conduta criminosa. Neste trabalho estudaremos a posição do Estado enquanto repressor.

\subsection{2 - As preferências dos atores}

Para saber quais as preferências dos atores temos que passar pelos debates que estão por trás destas possíveis escolhas ideológicas.

Ao se defrontar com este problema, ROHDE (1976, p. 70) propõe que, no caso dos juízes americanos, o benefício que eles procurariam seria o reconhecimento político. Pelo estudo de BONELLI (1995, p. 60), no caso do Brasil teríamos a percepção por parte dos juízes de duas clivagens, uma quanto à carreira 
e outra política. Estas clivagens poderiam ser indicativas dos objetivos destes juízes e estão ligadas à orientação política e profissional. Outras possíveis clivagens são as visões do direito e, especificamente, do direito penal, ou diferenças quanto à interpretação do direito.

A discussão ideológica acerca das visões do direito percorre a ciência política há tempos. Teoricamente ela foi feita por alguns dos mais importantes autores da teoria política contemporânea e está presente no debate atual. Para classificar este debate utilizaremos a tipologia que SCHMITT $\left(1934^{a}\right)$ propõe sobre os posicionamentos possíveis frente ao direito.

A fundamentação do direito é dada por três formas distintas de pensamento: uma regra, uma decisão ou um ordenamento. A partir destas é que se define o entendimento do que é o núcleo do direito. O pensamento normativista aparece nesta tipologia como impessoal, enquanto o decisionista como pessoal e o ordenamento como supra-pessoal.

A primeira forma seria fundada na idéia do governo pela lei. Esta forma procura acabar com as contradições do sistema a partir da concordância das decisões dos juízes a esta estrutura hierarquizada de normas, cabendo apenas ao juiz aplicá-la, não deixando espaço para o arbítrio pessoal.

A forma de ordenamento, ao contrário, partiria da idéia de que um arranjo institucional de um determinado Estado, família ou grupo é que daria as bases para o direito, e a norma seria conseqüência desta organização, reproduzindo-a para restabelecer a normalidade do ordenamento.

Por fim, a forma decisionista tem sua base não no ordenamento nem na lei, mas na decisão tomada por um soberano, que é aceita e põe ordem a um quadro que se apresentava desordenado. 
As formas que assumem os ordenamentos jurídicos ocidentais, seja românico-germânica, com suas leis escritas e codificadas, seja common law, baseados na jurisprudência, conjugariam duas destas formas de pensar jurídicas. Num primeiro momento, a decisionista, por meio da criação da lei por um parlamento ou pelas decisões primeiras da corte, e a normativa, que passaria a reproduzir esta forma decidida inicialmente, extraindo dela sua validade.

A partir desta classificação vamos expor as idéias em ordem cronológica, abordando em primeiro lugar WEBER (1922). Analisando o desenvolvimento jurídico e sua forma específica ocidental, ele defende que os países onde se implantou a forma moderna de capitalismo apresentam um padrão de decisões racionais. Além deste processo de racionalização, que diminuiu cada vez mais os formalismos típicos do direito medieval, houve uma especialização dos diferentes tipos de direito, definidos não mais por estamentos, mas pelo objeto de suas ações, como o direito comercial.

WEBER (1922) enxerga dois tipos de desenvolvimento do direito moderno, sendo que o primeiro pode ser encontrado nos países que adotam a codificação, com uma crescente tecnificação na formulação das leis, cada vez mais atribuindo ao juiz um mero papel de técnico judiciário, cumpridor de leis dentro de uma ciência jurídica. No segundo tipo, adotado pelos países do common law, o direito é elaborado pelos juristas, mas com uma peculiaridade: estes juristas, em sua maior parte, eram anteriormente advogados e os custos do processo eram altos. Com isto, este sistema passa a estabelecer um padrão de resposta seguindo os casos precedentes, respondendo em virtude dos interesses de uma elite.

Outra forma de direito, a qual WEBER (1922) faz uma ressalva, seria o direito a partir dos tribunais de júri, em que cidadãos comuns julgam os casos, como 
nos Estados Unidos. Ele vê um perigo nesta forma, pois não responderia à necessidade de previsibilidade que a organização racional capitalista prescindiria para executar seus cálculos.

WEBER (1917) também defende que nas modernas sociedades capitalistas há uma necessidade da racionalização do direito e do conhecimento prévio das decisões jurídicas como uma máquina, na qual, sabendo os dados apresentados para julgamento, espera-se um resultado prognosticável ou calculável. Esta forma só é possível com a adoção de normas gerais fixas, sem uma eqüidade individual para cada um dos casos. Esta norma não é necessariamente um código escrito, mas pode ser a repetição de um padrão de julgamento por um grupo de juízes sociabilizados dentro de uma dada realidade de decisões, como na common law.

A posição de WEBER $(1917,1922)$ é claramente a do direito positivo. Escrevendo num momento em que este sistema ainda estava em implantação, ele se junta a esta tradição e adota uma postura um tanto mecanicista do direito. Pela tipologia de SCHMITT $\left(1934^{\mathrm{a}}\right)$, ele assume a posição decisionista, quanto às funções do parlamento, e normativista, quanto aos papéis do judiciário. O júri expressaria a posição do ordenamento, a posição da sociedade frente ao caso apresentado.

Passada a crise dos anos 1920, as teorias escritas nos anos 1930 caminham em sentido contrário deste direito positivista, com resultados preditos. Nos pensadores da esquerda e da direita esta crise se manifesta, sendo exigido um novo papel para o direito e o processo de decisão judiciária.

Tentando formular uma proposta para o Direito Nacional Socialista, SCHMITT $\left(1934^{a}\right)$ defende uma superação desta forma e apresenta uma forma 
decisionista que consideraria a realidade dos diversos ordenamentos e visaria a sua manutenção, acabando com o elemento de estabilidade da lei dado pelo positivismo.

Nesta linha SCHMITT $\left(1934^{\mathrm{b}}\right)$ defende a possibilidade do Führer exercer a judicatura legítima. O pensamento jurídico normativista seria ineficiente, pois encobriria uma série de subterfúgios para tornar o Estado ineficiente para punir os seus inimigos. Assim, a justiça exercida pelo Führer não precisaria ser pautada em decisões anteriores, mas poderia ela mesma identificar os inimigos do Estado e ao mesmo tempo determinar a sentença.

Esta noção da distinção entre amigo e inimigo é vital no pensamento deste autor (SCHMITT, 1932). A especificidade das ações e dos motivos políticos é dada por esta distinção. Ao identificar os inimigos do Estado e puni-los, o Führer estaria unindo o político e o jurídico, incorporando o direito ao âmbito da política.

No outro extremo aparece o pensamento da esquerda. GRAMSCI (1991) defende que o direito deve ter um papel educador dentro da construção de uma nova forma de governo, mas o seu elemento novo não é dado por uma estrutura pré-existente, mas por algo que deve ser construído pela revolução.

Este direito novo não pode ser encontrado em doutrinas pré-existentes. Deve ser um instrumento, juntamente com a escola, que faça surgir novos costumes e hábitos, além de um meio pelo qual a superestrutura interfira na estrutura, racionalizando-a e a modificando.

Esse direito reflete a posição de um grupo hegemônico dentro do Estado e está acima do costume. Só no momento da revolução é que existe o espaço para que o costume se imponha ao direito, e que o costume da classe que ascende assume a forma de direito e se imponha às demais, educando-as. Esta teoria 
também defende um direito decisionista, ativo politicamente, mas uma decisão que deve emanar da classe revolucionária.

Estes autores, de certa forma, tentam dar uma resposta à crise que se instalou no direito positivo nos anos 1920 e o caminho parece ser o do decisionismo, embora o ator que tem o poder para tal seja diametralmente oposto nas teorias.

Finda a guerra e após passar por experiências totalitárias, o debate parece abandonar o decisionismo puro dos anos 1930 e reincorpora alguns dos elementos do positivismo.

A primeira autora deste período que abordaremos será ARENDT. Para entender sua posição vamos nos remeter ao texto em que comenta os movimentos americanos de Desobediência Civil (1973).

Comentando estes movimentos, ela defende uma visão contratualista do pacto social. No caso americano, o modelo adotado foi o de LOCKE, atribuindo um grande poder à sociedade civil que se sobrepõe às vontades individuais. No entanto este contrato excluiu tanto os indígenas quanto os negros do corpo de consenso, e quando estes grupos emergem organizados, procurando seu espaço dentro da sociedade, eles entram em choque com as instituições. A partir deste conflito, ela determina o espaço do direito e do sistema judiciário, bem como o espaço pelo qual estas demandas poderiam entrar no sistema.

O direito deve ter a função de garantir o cumprimento da lei, e esta é sua característica universal. Ele é um núcleo duro que garante a manutenção de uma ordem criada por outras instâncias, no caso do contrato americano, pelo Congresso. Exigir do direito que interfira em assuntos políticos geraria um foco de desestabilização do sistema social como um todo. 
Defendendo a legalidade destes movimentos dentro da sociedade americana, o espaço para sua ação estaria não no judiciário, mas na sua incorporação na arena decisória, no Congresso Nacional. Desta forma, a posição de ARENDT (1973) quanto ao judiciário é muito próxima do positivismo, cabendo a este poder julgar apenas a validade ou não de uma dada ordem, de acordo com os limites legais decididos nas arenas deliberativas da sociedade.

O único espaço decisionista do judiciário seria julgar a validade ou não das normas. Para isto, como no caso das legislações discriminatórias dos estados do sul dos Estados Unidos, o judiciário deve se pautar numa contradição entre a legislação destes estados e a legislação federal, baseando sempre sua decisão em leis préexistentes.

Há uma retomada da visão positivista no judiciário, restringindo o decisionismo ao poder legislativo, mas incorporando estes grupos minoritários na decisão daquela esfera.

Nesta retomada de um discurso que busca um direito que garanta a segurança social também temos LUHMANN (1983), que parte dos indivíduos para chegar à sua concepção geral do direito. Em primeiro lugar, os indivíduos têm expectativas, que levam a frustrações ou a contentamentos. Caso uma expectativa não seja atendida, ela pode acabar com as experiências acumuladas e levar a respostas destrutivas do sistema.

O direito surge como uma forma social que dá uma resposta a este processo. O direito identifica as expectativas de alguns campos que as sociedades julgam importantes, respondendo a estas expectativas com um padrão generalizado a partir das respostas individuais. Em outros campos ele deixa a liberdade aos indivíduos. 
No processo histórico, o recurso à força física vai deixando este padrão, sendo que primeiro ele passa para a sociedade e depois se abstrai, e o direito recorre a outros meios para se fazer cumprir, deixando de lado a punição sobre o corpo do indivíduo.

Na sociedade ocidental o direito assume a forma de direito positivado. Ele é fruto de uma sociedade que vai se complexificando em vários subsistemas que necessitam de respostas próprias. Neste processo não há mais um direito divino, dos costumes, mas um direito que espelha a vontade de um legislador mutável, sensível às necessidades de cada momento, e que produz as normas. $\mathrm{O}$ direito nesta concepção é fruto de uma decisão, e não se pauta numa estrutura hierárquica racional de normas, como na construção Kelseniana.

Estas normas devem pautar a ação dos juízes e fornecer os princípios pelos quais os juízes devem decidir provisoriamente, enquanto o legislador não supre as lacunas do sistema e não existe a legislação geral e abstrata que dê uma resposta normativa aos casos individuais.

No entanto, segundo LUHMANN (1985), as possibilidades de mudança deste sistema estão restritas a uma mudança similar no sistema social. Mudanças de legislação e de jurisprudência só podem ser acompanhadas de mudanças nos sistemas que se relacionam com esse, que esperam por esta nova postura.

Ele tenta conjugar as três possibilidades de pensamento jurídico, dando uma importância maior para o normativismo na esfera jurídica, mas as outras duas dimensões estão presentes, e acabam por interagir na decisão do juiz.

Já HABERMANS (2003), em certa medida, considera esta dimensão decisionista mais importante na decisão jurídica, mas não faz a retomada do 
decisionismo dos anos 1930, e sim um novo decisionismo que procure um padrão mais estável de decisões.

Ele concebe o direito dentro da sua teoria do discurso e vê a decisão do juiz e o processo legislativo como as etapas que vão dar validade às decisões jurídicas, não como uma busca da verdade racional. Este discurso procura uma legitimação dentro da razoabilidade e não na razão universal procurada por KANT.

A legislação deve ser construída por um processo discursivo, no qual as partes que vão sofrer suas conseqüências possam participar da sua elaboração e da construção de um discurso socialmente válido. Para isto, nas sociedades modernas, é imprescindível uma arena de debate de discursos que seja sensível aos diversos grupos que compõem a sociedade.

A construção do discurso jurídico, por sua vez, reserva ao juiz uma possibilidade decisionista de fazer uma construção para dar fim ao litígio entre as partes. No entanto esta construção deve obedecer alguns princípios para que tenha eficácia e validade.

A decisão do juiz deve ser construída dentro de um sistema jurídico coerente, e procurar uma padronização sistêmica por meio de argumentos mais próximos da construção normativa. O juiz tem a liberdade de utilizar sua técnica para levar os argumentos da parte à construção de um discurso que represente uma saída mais próxima de um standard posto pela sociedade através da sua instância discursiva legislativa.

Para que haja uma padronização é imprescindível uma estrutura de revisão que garanta o máximo possível de uniformidade de discursos, e que esta uniformidade seja coerente. Só por meio desta construção institucional é que HABERMAS (2003) vê a possibilidade da eficácia e validade do discurso jurídico. 
Este debate está presente na agenda política atual, ligada sobretudo à questão da súmula vinculante, à necessidade da padronização das sentenças de primeira instância a dos tribunais, e à postura que o juiz deve ter frente ao direito.

Analisando as correntes ideológicas presentes na magistratura, FARIA (1991) as associa ao que ele vê como conflitos de paradigma pelos quais passa o direito. Para ele, existiriam duas posições antagônicas: a concepção instrumental do direito e a concepção problematizante do direito. Sua discussão gira em torno dos pólos do direito normativista e do direito organizacional, embora em outros trechos ele reconheça a presença dentro do sistema de posições que classificaremos como decisionistas.

Partindo para estudos empíricos, nas pesquisas realizadas pelo IDESP em 1993 e por VIANNA (2001), esta divisão aparece, mas em termos pouco claros. Segundo SADEK (1995 , p. 22-23), embora 73,7\% achem que os juízes não devem ser meros aplicadores da lei, só $11 \%$ dos juízes acham que a estrutura do direito positivo não permite um espírito crítico. Outras perguntas que poderiam significar uma disposição de atuar fora da lei contam com pequeno apoio dos entrevistados.

Os resultados encontrados por VIANNA (1997, p. 258-263) também vão neste sentido, mostrando que a grande maioria se posiciona por um judiciário preso à aplicação da lei e uma pequena parcela, cerca de $11 \%$, desempenhando uma posição de vanguarda revolucionária, caminhando no sentido de GRAMSCI.

Outro problema levantado no direito penal foi a influência da personalidade do juiz sobre a sentença. No estudo por GAUDET (1938), são apontados dois tipos de personalidade de juízes: as brandas e as severas; e estas personalidades se expressariam em suas decisões, em penas mais brandas e mais severas respectivamente. 
Esta diferença de personalidade pode se manifestar, no caso do direito penal, na discussão em torno da natureza da pena e da punição. A doutrina jurídica se divide em três correntes teóricas quanto às justificativas das penas: a teoria retributiva, da prevenção especial e da prevenção geral.

A teoria retributiva desenvolve-se, sobretudo, no século XVIII e XIX e procura ver a pena como um mal ao condenado na mesma intensidade do executado contra o sistema penal. É uma reaplicação da justiça de Talião. A teoria da prevenção especial, defendida por VON LIZT, MARC ANCEL e FERRI, procura prevenir que o autor de delitos volte a cometê-los, corrigindo-o, intimidando-o ou tornando-o inofensivo privando-o da liberdade. Por fim, a teoria da prevenção geral formulada por FLEUERBACH e BENTHAM, defende a aplicação da pena para intimidar a generalidade das pessoas para que estas não cometam os mesmos delitos (SHECAIRA, 1991, p. 41).

Dentro desta perspectiva as penas restritivas possibilitariam uma reinserção do delinqüente à sociedade e dariam uma melhor idéia de punição em comparação com sistema prisional.

A legislação penal brasileira, com a reforma de 1984, abriu a possibilidade para a adoção de penas restritivas de direito, genericamente chamadas de penas alternativas. Pela legislação vigente, estas penas são autônomas e substitutivas das penas privativas de liberdade; no entanto não são independentes destas. As penas restritivas estão vinculadas às penas privativas tipologisadas na parte específica do código penal e as substituem.

Após a reforma de 1998, para os crimes dolosos, os requisitos para sua adoção são o prazo máximo da pena de 4 anos; o crime não ter sido cometido com violência e grave ameaça a pessoa; e o réu não ser reincidente neste tipo de crime. 
Para os crimes culposos não há esta restrição. A legislação também destaca que sejam levadas em conta as características do réu para que a pena seja suficiente.

A partir da condenação e da fixação da pena, o juiz pode converter a pena privativa em pena restritiva, e caso esta não seja suficiente, pode retornar à pena privativa de liberdade. Os tipos de penas restritivas previstas são: a prestação pecuniária, a perda de bens e valores, a prestação de serviço à comunidade ou a entidades públicas, a interdição temporária de direitos e a limitação de fim de semana.

Segundo D'URSO (2002), pelas regras firmadas na $8^{\circ}$ Congresso das Nações Unidas Sobre a Prevenção dos Delitos e Tratamento dos Delinqüentes, as penas alternativas devem obedecer certas regras mínimas, expressas na resolução 45/440.

Os princípios defendidos nesta resolução seriam: a legalidade; a individualização da pena; a proporcionalidade; o devido processo legal; a humanidade; e a dignidade da pessoa humana.

Tais penas devem ser efetivamente cumpridas e os delinqüentes devem ser assistidos social, psíquica e materialmente, fortalecendo seus vínculos com a sociedade. O objetivo de tais penas seria transmitir o efeito de uma sanção cumprida contra o delinqüente procurando objetivo de evitar a reincidência.

As penas também nunca podem exceder o prazo pré-estabelecido, e em caso de reação favorável, deve ser prevista a interrupção antecipada. A resolução também orienta punir o delinqüente com outra medida substitutiva, caso não se cumpra a sansão, deixando a reclusão como última opção.

Dentre as penas substitutivas, a principal alternativa é a prestação de serviços à comunidade. A primeira experiência moderna de prestação de serviços à 
comunidade, dissociada da idéia de trabalhos forçados, surgiu com o Código Penal Soviético de 1926, e, posteriormente à Segunda Guerra Mundial, foi estendida aos países do leste europeu. Nesta experiência o condenado trabalhava alguns dias por ano sem receber, como forma de punição (SHECAIRA, 1991,p. 56).

Em 1972, a Inglaterra adota através do Criminal Justice Act o Community Service Order. Por esta experiência o condenado não reincidente trabalhava entre 40 e 240 horas nos períodos de tempo livre, um funcionário do probation service deveria emitir um relatório, o social enquiry repor. Em caso de descumprimento o juiz poderia arbitrar uma multa (idem, p. 58).

O número de penas deste tipo saltou de 1.019, em 1974, para 15.700 em 1979, chegando a 34.500, em 1983, sendo que neste ano elas correspondiam a $41 \%$ das sentenças de furto, e $25 \%$ de roubo (p. 59 ).

Analisando a percepção da população sobre a melhor pena para os tipos penais, o texto de GIBBONS (1969) faz uma pesquisa junto à população de algumas grandes cidades americanas. Esta pesquisa aponta que para os crimes contra a pessoa e crimes contra o patrimônio a melhor pena ainda é a privativa de liberdade. Para as penas contra os costumes e porte de drogas, a melhor pena é o pagamento de multa ou um dispositivo parecido com o sursis, a probation.

Esta percepção pode ter mudado, dado o tempo transcorrido desde a realização desta pesquisa, mas levanta uma dimensão importante da pena: a percepção dos cidadãos, um importante componente da avaliação do judiciário e da percepção da eficácia deste sistema em punir.

No caso das alternativas ao encarceramento, em pesquisa realizada junto a uma amostra da população carioca, LEMGRUBER (2001) defende que, em casos de 
crimes de pouco poder ofensivo, há uma grande aceitação deste tipo de pena pela população.

Este debate também é pautado por uma última dimensão ligada ao modelo legalista e que procura dentro do próprio sistema jurídico a explicação para a decisão judicial. É uma derivação da hermenêutica jurídica, procurando adequá-la à ciência política. O grande problema desta teoria é enfrentar a questão da discricionariedade do juiz para decidir os casos de lacuna da lei ou de questões difíceis.

O marco da teoria legalista no século XX é o trabalho de KELSEN (1998). Neste trabalho o direito é visto como um sistema piramidal de normas, no qual as normas superiores vão dando validade às normas inferiores. Assim, o juiz deve decidir dentre as possibilidades que o sistema impõe, e orientado por estas normas superiores. Esta corrente positivista entende que o direito é posto pelo Estado e se desenvolveu ao longo do século XX polarizando o debate.

Outras correntes teóricas aparecem para se contrabalancear a esta interpretação. BOBBIO (1993) com a teoria da norma jurídica, defende a procura dos valores naturais para se extrair a interpretação da norma. DWORKIN (IKAWA, 2004) procura uma interpretação holística dos princípios do sistema para, a partir daí, suprir as lacunas.

No caso brasileiro, a legislação e a doutrina acabam por seguir a vertente positivista, e no caso penal há um preceito que impede o uso da analogia para suprimir as lacunas, é o princípio do nullun crimen, nulla poena sine lege, previsto no ordenamento. Ele prega que só há crime quando previsto por lei anterior, suprimindo a possibilidade de lacunas pois o ordenamento entende que aquela não é uma 
conduta delituosa, portanto o valor não está sujeito a tutela do Estado. A única analogia aceita seria em favor do autor do delito (TOURINHO, 2000 ${ }^{\text {, }}$ p. 177-178).

Da discussão precedente podemos tirar as possibilidades de escolha que os juízes têm e que na nossa opinião contemplariam as possíveis variações ideológicas deste grupo. A primeira dimensão é a variação ideológica política entre esquerda e direita. A segunda dimensão é uma visão mais ampla quanto à postura frente ao Direito, expressa no debate em torno da tipologia de SCHMITT (1934¹). A terceira dimensão, qual a interpretação do direito penal e a natureza da pena que poderiam ser aplicadas, e a quarta visão, a discussão legalista e as formas de enfrentar as lacunas da lei.

Quanto à motivação dos promotores e advogados, há um grande problema para as conhecer, pois ambos podem ter motivação política e profissional, visto que 1/5 das vagas dos tribunais são preenchidas por indicação das entidades profissionais destes atores (art. 94 da Constituição Federal). O problema para a pesquisa é a não documentação destas motivações, pois eles não são obrigados a expor a sua convicção, tal como os juízes.

\subsection{3 - As instituições que exercem restrições}

Além dos atores, temos que caracterizar a instituição onde ocorre o processo, e como ela está organizada. A instituição que iremos estudar, a justiça estadual paulista, foi organizada pelo decreto-lei complementar $n^{\circ} 3$ de 1969. Por este decreto o Estado é dividido em circunscrições, comarcas e distritos, mas o Tribunal de Justiça e os Tribunais de Alçada tinham jurisdição única sobre todo o Estado. 
As comarcas são divididas em quatro entrâncias de acordo com a classificação de receita tributária, número de eleitores e movimento forense dos municípios que as compõem. Estas comarcas constituem a primeira instância da justiça, e seus juízes têm jurisdição apenas sobre a área da comarca. As circunscrições são reuniões de comarcas contíguas e os distritos são subdivisões da comarca.

As comarcas da primeira instância não são obrigadas a terem varas especializadas para julgar causas cíveis ou criminais. Em geral somente as grandes comarcas apresentam esta especialização, com o quadro mais comum de uma mesma vara julgar questões cíveis e criminais. A única exigência é que cada comarca tenha um Tribunal do Júri para julgar casos de crime contra a vida, com exceção de homicídio culposo.

A segunda instância da justiça criminal era composta por dois tribunais: o Tribunal de Justiça e o Tribunal de Alçada Criminal. Estes tribunais tinham jurisdição sobre todo o Estado, sendo o Tribunal de Justiça dividido internamente em duas seções: a criminal e a civil.

Competia ao Tribunal de Justiça julgar ações penais relativas a: crimes sujeitos a penas de reclusão, exceto os delitos contra o patrimônio; crimes contra o patrimônio, quando ocorra o evento morte; infrações penais envolvendo tóxico ou entorpecentes; crimes falimentares; e crimes de responsabilidade de Prefeitos e Vereadores.

Ao Tribunal de Alçada Criminal (TACRIM) competia julgar ações penais relativas a: infrações penais a que não seja cominada pena de reclusão, excluídas as referentes a crimes de responsabilidade de Prefeitos e Vereadores, a tóxicos ou 
entorpecentes e a crimes falimentares; e crimes contra o patrimônio, exceto quando resultar o evento de morte.

As decisões administrativas quanto aos juízes eram tomadas por divisões internas do Tribunal de Justiça. Logo este seria o órgão que gozaria da maior parte das restrições administrativas. Já ao TACRIM restariam mais restrições de ordem processual, agindo na reforma da decisão destes juízes.

\subsection{4 - As restrições}

Se não houver uma restrição para operar suas preferências cada ator deve manifestar suas opiniões, dando respostas que maximizem suas utilidades e fazendo com que o sistema opere de forma anárquica.

Segundo SEGAL (2002, p. 94-97), quanto às restrições a Suprema Corte gozaria de grande liberdade, visto não estar sujeita a novas eleições e nem precisar de accountability, só podendo ser teoricamente restringida pelo Congresso, embora esta prerrogativa nunca tenha sido utilizada. Já as cortes inferiores estariam submetidas à restrição das eleições para alguns cargos, e em alguns Estados, à possibilidade prática de revisão por senadores.

No caso brasileiro não é possível pensar nestes termos, visto que o ingresso ao cargo da magistratura ocorre por meio de concurso ou por meio do Quinto Constitucional. A Constituição Federal de 1988 também estabelece uma série de garantias e procedimentos para a promoção da magistratura, que influenciam na construção do modelo racional.

Temos que buscar as restrições para a ação coletiva na legislação. O artigo 95 da Constituição de 1988 garante aos magistrados a vitaliciedade, a inamovibilidade e a irredutibilidade dos salários. Segundo o artigo 93, inciso VIII, 
para remover um juiz, disponibilizá-lo ou aposentá-lo por interesse público, é necessário 2/3 dos votos do tribunal.

A outra regra que poderia restringir a magistratura é a promoção. No entanto, o artigo 93, incisos II e III estabelece que a promoção se dará alternadamente por antigüidade e merecimento, mas mesmo o merecimento só pode ser aplicado aos juízes que estão entre os $20 \%$ mais velhos na lista de antigüidade. Na promoção por antigüidade, para recusar o juiz mais antigo é necessário o voto de 2/3 dos membros do tribunal.

Assim, os instrumentos de restrição seriam poucos para conseguir alterar a conduta dos juízes. O que se esperaria por meio desta construção teórica é que os juízes agissem de acordo com seus próprios valores políticos e ideológicos, o que poderia ocasionar uma variedade maior nas sentenças.

Além dos juízes, temos que estudar as restrições a outros atores do processo: os promotores de justiça e os advogados.

Também é difícil medir as restrições impostas a estes atores que, por parte dos tribunais, poderiam sofrer sanções por litigância de má fé (recorrer de uma sentença só para postergar uma decisão). No entanto, no caso do recurso à segunda instância e na justiça penal este tipo de punição não é aplicada, pois a doutrina entende como princípio processual o duplo grau de jurisdição (CINTRA, 1993).

A única restrição possível, a nosso ver, seria o preenchimento das vagas nos Tribunais por indicação das entidades profissionais destes atores, conforme estipula o artigo 94 da Constituição Federal. Esta indicação também passa por um filtro no Tribunal que restringe a lista sêxtupla a uma lista tríplice, que será 
submetida à escolha do chefe do Executivo, todavia, mesmo esta restrição é muito tênue para alterar as condutas destes atores. 


\section{3 - Metodologia da pesquisa}

\section{1 - As fontes de dados.}

Para desenhar a pesquisa temos que conhecer o processo penal e suas etapas para poder identificar os pontos onde podemos colher informações.

O fato penal começa com o fato concordante com um tipo penal descrito na legislação, mas esta fase não pode ser mensurada com precisão porque o fato concordante não vai necessariamente resultar num inquérito policial, e muitos nem chegam ao conhecimento da autoridade policial. Uma tentativa de mensurar seria através de pesquisas de vitimização, mas estas pesquisas se restringem a características aparentes do criminoso, não permitindo caracterizações sócioeconômicas do mesmo. O máximo que estas pesquisas permitem são identificar os perfis das vítimas e os ambientes nos quais ocorrem os fatos delituosos, o que foge do objetivo deste trabalho.

Esta pesquisa se baseará em dados oficiais, documentados na estrutura oficial de entrada de dados no sistema de justiça criminal, cuja estrutura está descrita no código de processo penal (CPP).

A entrada ocorre com o inquérito policial ou por meio de uma informação ao Ministério Público (MP).

O inquérito policial é instaurado por iniciativa do delegado mediante requisição do MP, da autoridade judiciária ou por requerimento da suposta vítima, conforme dispõe o artigo $5^{\circ}$, incisos I e II do CPP. O inquérito procura conhecer o suposto autor da infração, colher informações a respeito do fato infringente da norma e das circunstâncias motivadoras, repassando estas informações ao MP, que a leva 
ao conhecimento do juiz, para instalar ou não o processo (TOURINHO FILHO, $2000^{a}$, p. 18-19).

A outra porta do sistema é o Ministério Público, conforme dispõe o artigo 27 do CPP.

"Qualquer pessoa do povo poderá provocar a iniciativa do Ministério Público, nos casos em que caiba a ação pública, fornecendo-lhe, por escrito, informações sobre o fato e a autoria e indicando o tempo, o lugar e os elementos de convicção."

Esta etapa do fluxo apresenta um problema para sua análise, uma vez que ela é permeável a uma seleção subjetiva por parte dos agentes do Estado. Desta forma o agente, ao receber a denúncia, pode desencorajar o denunciante a continuar ou proceder a uma negociação informal que resulte na solução do problema sem que seja documentado ou registrado, dificultando a sua análise.

A partir da denúncia do Ministério Público o fluxo pode ser acompanhado porque suas várias etapas ficam registradas, sendo que o inquérito policial e as denúncias só poderão ser arquivados pela autoridade judiciária, uma vez que só ela tem competência para proceder ao arquivamento.

Esta nova etapa cabe ao juiz e seu primeiro procedimento é tentar a conciliação entre as partes envolvidas. Caso aceitem, esta decisão é escrita e não admite recurso; não sendo, a etapa seguinte é a instauração do processo. No caso dos tipos penais analisados esta possibilidade praticamente inexiste pois só é aplicada aos crimes com pena inferior à 2 anos, embora na pesquisa tenham sido encontrados alguns casos no qual a transação foi aplicada.

Uma vez instaurado o processo, o juiz pode suspendê-lo a pedido do Ministério Público. Esta decisão geralmente é aplicada aos crimes de baixo poder ofensivo, com pena mínima igual ou inferior a um ano, ficando o processo em 
suspenso pelo período de 2 a 4 anos, findo o qual se extingue. Neste caso também é muito difícil ocorrer o recurso, pois é obrigatório que o pedido de suspensão seja formulado pela acusação, no caso o Ministério Público, e ser do interesse do réu não responder ao processo.

Não incorrendo nestas duas possibilidades, o processo segue seu trâmite normal e é prolatada a sentença. Durante este trâmite pode ocorrer uma série de recursos, mas estes estão ligados mais à forma como se conduz o processo do que propriamente ao mérito da sentença, não sendo alvo de nossa pesquisa.

O objeto de análise deste estudo será a ficha de andamento dos processos, que faz um resumo da sentença e traz as seguintes informações: a descrição de características dos réus, a data da denúncia, a base legal da denúncia, a data da sentença, a sentença resumida, a base da sentença, e se houve recurso de alguma das partes.

Sendo recorrida a sentença, ela era encaminhada, de acordo com a matéria, para o Tribunal de Alçada Criminal ou para o Tribunal de Justiça. Nestes tribunais era feito o acórdão dos desembargadores a respeito do recurso, subdividindo-se no acórdão propriamente dito (a decisão da turma de desembargadores); na ementa (um resumo com os pontos principais tratados no acórdão); no relatório (a descrição do caso e da decisão do juiz de $1^{\text {a }}$ instância); e no voto dos desembargadores, quando é apresentada a justificativa para se manter ou reformar a decisão recorrida. Na figura I temos o fluxograma do processo de rito comum, que será o objeto de nossa análise. 
Figura I - Fluxograma do processo de furto e roubo
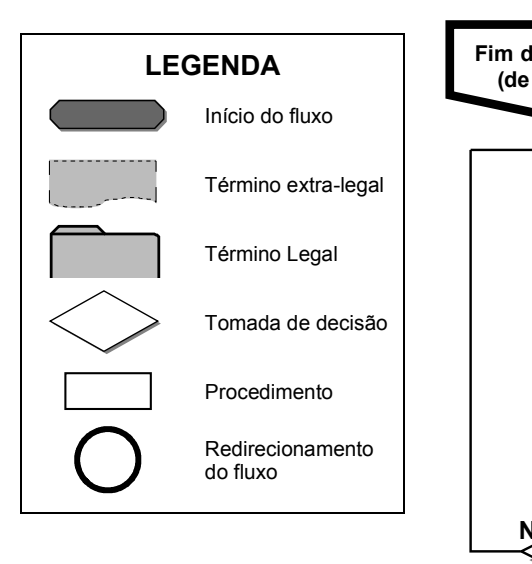

Fim do Processo Pena
(de conhecimento)

VARA DE EXECUÇÕES CRIMINAIS

I $--------j--$
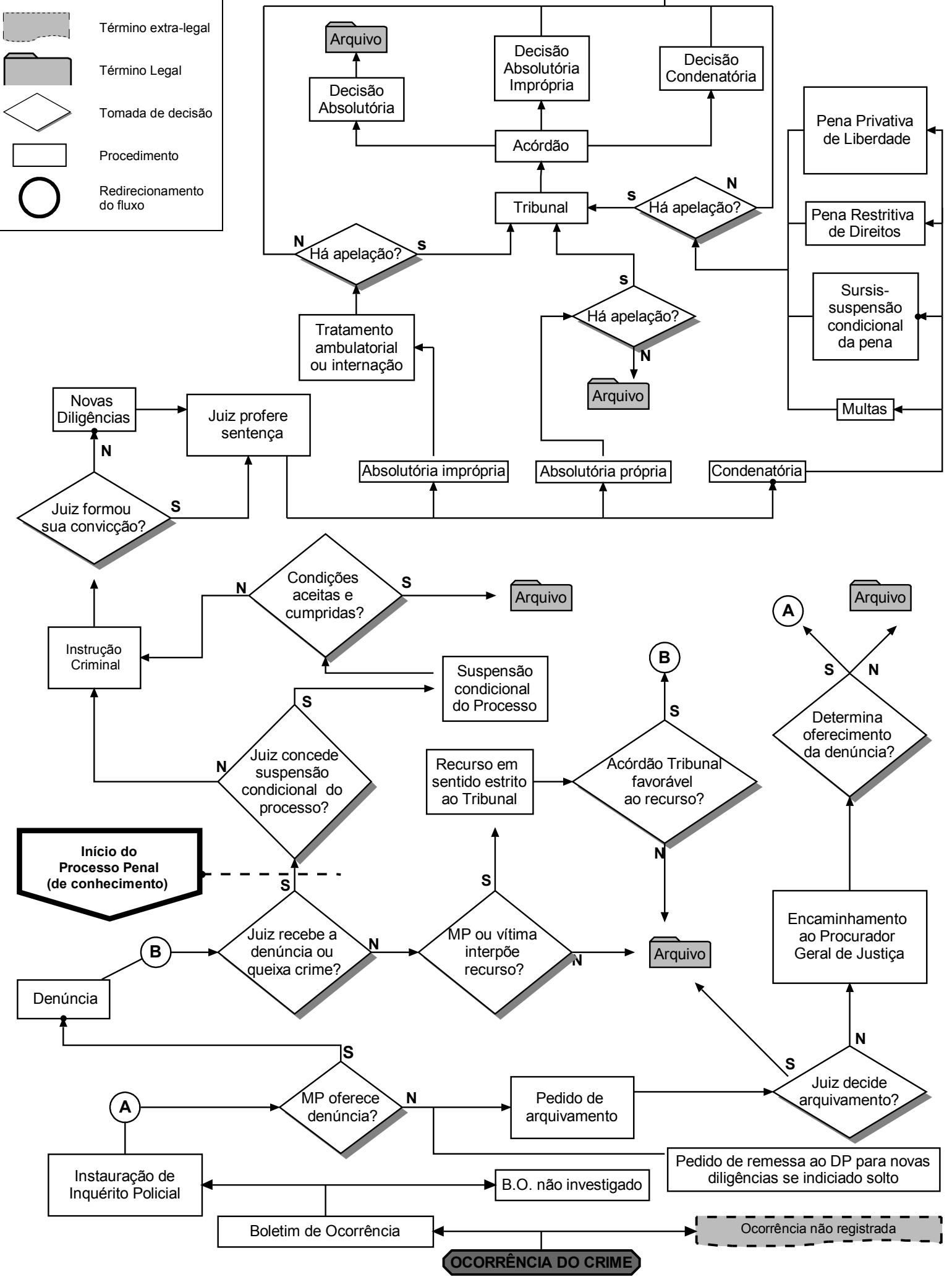

Fonte: Convênio FSEADE - IBCCRIM 
Além das informações processuais que servirão para a parte da pesquisa sobre os estudos de sentença e de características processuais, temos que coletar informações para fazer as inferências relativas ao modelo atitudinal.

Partindo do pressuposto da teoria dos jogos, segundo o qual os resultados finais são conhecidos, e assumindo como modelo o recurso mais comum, que se encerra na segunda instância da Justiça Estadual, a análise tem que se basear nos resultados destes recursos para julgar as motivações dos atores de primeira rodada: os juízes de primeira instância; e os jogadores de segunda rodada, os promotores e advogados que formularão ou não os recursos. O jogo está graficamente representado na figura II.

FIGURA II - Jogo do processo penal e atores estratégicos envolvidos

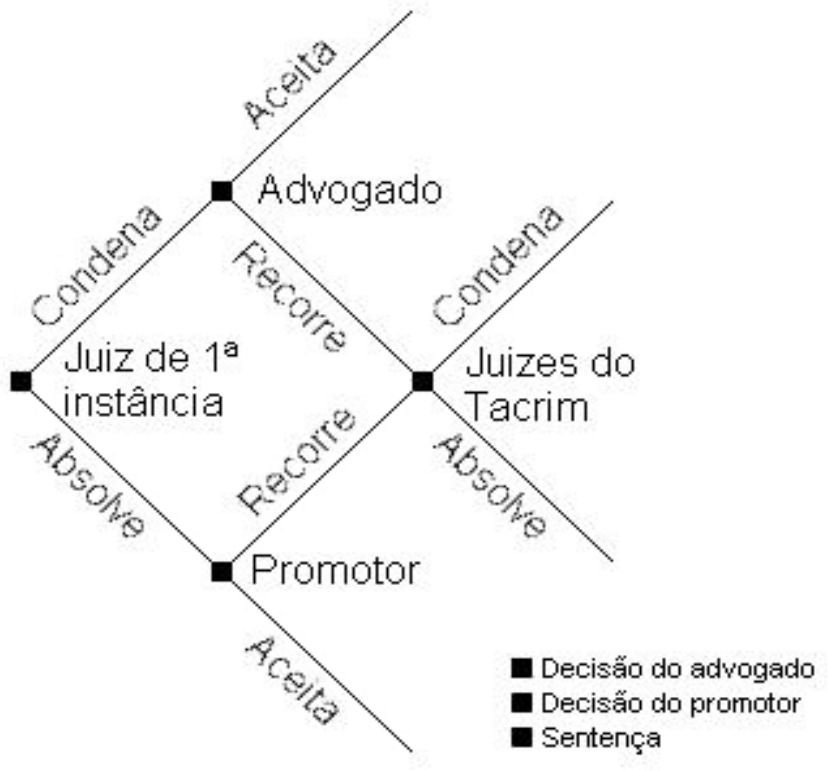

Não foi possível realizar o acompanhamento do jogo completo porque não conseguimos agregar o resultado final do processo na segunda instância ao banco de dados da pesquisa. A numeração dos processos de primeira instância não é a 
mesma da segunda e, conseqüentemente, no banco de dados consultado não foi possível estabelecer uma chave entre as numerações.

Vamos tomar como resultado o jogo na segunda rodada e criar um modelo que teste a existência de alguma variável importante no processo, nos réus ou nos juízes que seja importante para predizer o resultado do processo.

Como as informações referentes aos promotores e aos advogados são extremamente limitadas e seria necessário estender a pesquisa em demasia para poder contemplar estes atores, restringiremos esta parte da pesquisa à atuação estratégica dos juízes. Os demais atores serão incluídos no modelo, mas trataremos apenas de definir as regras dos jogos que motivam estes atores a recorrer, ou seja, as características dos processos que estimulam o recurso, utilizando as informações coletadas na pesquisa de processos.

Para tentar captar a motivação dos juízes utilizaremos um survey com perguntas referentes à divisão ideológica da magistratura e ao posicionamento político. O questionário da pesquisa junto aos juízes foi baseado nas pesquisas realizadas pelo IDESP (1993), por SADEK (1995 ) e por VIANA (1997) e tentou captar a divisão ideológica da magistratura para compará-la ao resultado do processo e identificar possíveis padrões de conduta destes juízes.

Esta divisão estaria presente nas seguintes questões:

A. O compromisso com a justiça social deve preponderar sobre a estrita aplicação da lei.

B. A aplicação da lei sempre beneficia os privilegiados.

C. $O$ direito positivo não permite o espírito crítico.

D. O judiciário deve desempenhar um papel ativo no sentido de reduzir as desigualdades sociais. 
A idéia por trás deste conjunto de questões é tentar captar uma postura distinta quanto ao direito, sobretudo em relação à discussão entre um direito normativista e um direito decisionista.

O direito enquanto ordenamento não é factível de ser captado, pois esta classificação está vinculada à idéia de um tribunal de júri que expresse a posição da sociedade quanto ao assunto. O juiz, ao aplicar a sua interpretação da sociedade para decidir um caso, não estaria propriamente exercendo este direito de ordenamento, mas mais uma atitude decisionista a partir da sua interpretação. Como nos tipos penais estudados a possibilidade desta modalidade de julgamento não existe, esta categoria não faz muito sentido para nossa pesquisa.

Assim, a partir das respostas a essas questões será construída uma escala de decisionismo que varia de 0 a 10 pontos. O caso extremo que discordar de todas as respostas será o zero desta escala, o normativismo puro. O caso máximo de 10 pontos será o decisionismo puro.

O problema reside em como mensurar estas dimensões da personalidade, e para tal utilizaremos como proxy ${ }^{2}$ o posicionamento dos juízes em algumas das questões do questionário.

Desta discussão podemos retirar mais um índice de controle para aplicarmos em nosso modelo, extraindo-o do conjunto de questões formuladas aos juízes no questionário (Anexo 1) e que igualmente variam de 1 a 10 e expressam posições mais brandas e mais severas de acordo com o posicionamento frente ao direito penal.

\footnotetext{
${ }^{2}$ Proxy é uma medida indireta de uma variável que pretendemos mensurar através da mensuração de uma outra variável relacionada a esta.
} 
E. A idade penal deve ser reduzida para dezesseis anos.

F. Os tipos penais classificados como hediondos devem ser ampliados.

G. $O$ juiz deve pautar suas decisões pelo princípio do direito penal mínimo.

H. O juiz deve aplicar preferencialmente as penas alternativas à privação de liberdade.

Atribuiremos o valor mínimo da escala de severidade ao juiz que se posicionar discordando das duas primeiras e concordando com as duas últimas, e o máximo ao que concordar com as duas primeiras e discordar das duas últimas.

Este survey foi prejudicado pelo baixo índice de respostas ao questionário aplicado junto aos juízes da comarca de São Paulo. No entanto, procederemos a uma análise qualitativa do modelo, fazendo uma tipologia dos juízes que responderam ao questionário e estudando suas decisões para que pesquisas posteriores quantitativas possam generalizá-la para explicar o processo de decisão judicial.

Os resultados do modelo não permitirão generalizações, apenas servirão como um exercício exploratório e um pré-teste para possíveis pesquisas de maior envergadura, que possam contar com mais recursos humanos e maior prazo.

\section{2 - Definição e construção da amostra}

A análise que faremos pressupõe a criação de um banco de dados para cada um dos níveis da explicação. Para tanto, utilizaremos dois bancos de dados, sendo que o primeiro contém informações sobre o processo (denúncia qualificada, tentativa, sentença, regime da pena, substituição, recurso do Ministério Público e recurso do réu), sobre a vítima (natureza e sexo), as datas das diferentes fases do processo, informações dos réus (sexo, naturalidade, cor, estado civil, escolaridade, ocupação), a data do fato e a delegacia onde foi registrado. O segundo banco de dados foi construído a partir de um survey junto aos juízes da comarca de São 
Paulo, procurando medir as variáveis que a literatura pertinente julga importante para esta explicação.

O universo dos processos são os feitos distribuídos na comarca de São Paulo no ano de 2002 e que tenham por tipo penal o furto e o roubo. Este universo foi disponibilizado pelo distribuidor do fórum criminal da Barra Funda em formato de listagem, dividida por varas e por distribuidor.

Tabela VIII: Universo de processos nos departamentos de inquérrito policial (DIPO) e nas varas criminais (Vara), por tipo penal (em \%).

\begin{tabular}{lccc}
\multicolumn{1}{c}{ Processos } & DIPO & Vara & Total \\
\hline Processos de furto & 50,43 & 41,65 & $\mathbf{4 4 , 6 0}$ \\
Processos de roubo & 49,57 & 58,35 & $\mathbf{5 5 , 4 0}$ \\
\hline Total & $\mathbf{5 5 8 6}$ & $\mathbf{1 1 0 0 9}$ & $\mathbf{1 6 5 9 5}$
\end{tabular}

Fonte: Fórum Regional da Barra Funda

A amostra foi construída com a subdivisão em 20 pilhas dos relatórios de processos que se encontram nas Varas criminais, e outras 20 pilhas com os processos que se encontram nos Departamentos de Inquérito Policial. Foram geradas 40 tabelas de números aleatórios, sendo que 20 tabelas continham 175 números e definiram a amostra das varas de julgamento, e as outras 20 tabelas continham 89 números e definiram os processos nas varas de investigação. Os dados destes processos foram extraídos das fichas de andamento junto à base de dados do tribunal de justiça.

Tabela IX - Amostra de processos nos Departamentos de Inquérito Policia (DIPO) e nas Varas criminais (Vara), por tipo penal (em \%).

\begin{tabular}{llll}
\hline \multicolumn{1}{c}{ Processos } & DIPO & Vara & Total \\
\hline Processos de furto & 50,43 & 41,66 & $\mathbf{4 4 , 6 1}$ \\
Processos de roubo & 49,57 & 58,34 & $\mathbf{5 5 , 3 9}$ \\
\hline Total & $\mathbf{1 7 7 8}$ & $\mathbf{3 5 0 0}$ & $\mathbf{5 2 7 8}$ \\
\hline
\end{tabular}

Outra pesquisa, realizada junto aos juízes do Fórum Criminal da Barra Funda, aplicou um questionário (anexo I) com a reprodução de algumas questões 
aplicadas pelo IDESP em 1993 e pela pesquisa de VIANNA em 2001, acrescido de perguntas referentes às discussões presentes na doutrina de direito penal. Este questionário procurou fornecer dados para as variáveis ideológicas e políticas que serão utilizadas no modelo e que foram debatidas nos capítulos anteriores.

O universo destas entrevistas são 30 juízes do Fórum Criminal da Barra Funda, os quais participaram do julgamento dos casos de nossa amostra. No entanto esta parte da pesquisa foi prejudicada porque apenas 5 juízes se dispuseram a responder o questionário, e, em virtude da limitação destas informações, as conclusões que pressupõem o uso desses resultados não poderão ser generalizadas para o universo da pesquisa, embora as utilizemos como um préteste para pesquisas mais amplas que adotem a mesma metodologia. Esta informação será tratada de forma a criar uma tipologia dos juízes diferenciando suas respostas de acordo com os tipos que representam no debate ideológico.

Outra limitação metodológica foi a impossibilidade da aplicação direta dos questionários, os quais foram distribuídos pelo Setor de Administração do Fórum da Barra Funda aos juízes selecionados na amostra de processos, tendo estes os respondido diretamente.

Apesar destas limitações, resolvemos proceder a uma análise qualitativa dos questionários a fim de não perder a informação coletada, pois embora sejam informações com limitações, elas permitem perceber falhas da metodologia e do questionário e podem ser aproveitadas para indicar alguns possíveis caminhos para pesquisas mais amplas e generalizáveis para o universo estudado. 


\section{3 - A operacionalização do modelo}

A pesquisa será baseada na descrição das variáveis coletadas e na construção de modelos explicativos, derivados da literatura americana e brasileira, para testar as hipóteses levantadas no primeiro capítulo desta dissertação.

A descrição da amostra procurará descrever o perfil dos réus, das vítimas, dos juízes e das características dos processos penais de furto e roubo, para termos uma visão mais genérica do problema a ser enfrentado.

Os modelos testarão as hipóteses da literatura brasileira e americana, controlarão estas hipóteses pelas variáveis processuais e serão aplicados aos tipos penais furto e roubo.

Os primeiros três conjuntos de modelos são derivados dos estudos de sentença americanos, os quais ganharam força a partir dos anos 1960, com o surgimento da teoria do "conflito". Esta teoria sustenta que pessoas de baixo status sócio-econômico seriam discriminadas pelo sistema de justiça.

Tentando operacionalizar este problema, CHIRICOS e WALDO (1975) utilizam o tempo de condenação para fazer um teste empírico, analisando a sentença aplicada a 10.488 sentenciados em três Estados, para 17 tipos penais.

Posteriormente este estudo foi criticado por REASONS (1977), por GREENBERG (1977) e por THOMSON E ZINGRAFF (1981) que argumentam que a teoria do conflito defende punições mais severas para pessoas de baixo status sócio-econômico, e não necessariamente penas mais longas. Com isto, os percentuais de condenados a sentenças seriam mais altos entre os de baixo status, enquanto os de alto status teriam maior chance de serem condenados ao probation.

Os trabalhos que se seguiram, como os de MYERS E TALARICO (1987), DIXON (1995), STTEFENSMEIER (1999, 2000), passam a adotar estas duas 
propostas de medição para determinar se as sentenças sofriam ou não influência de outras variáveis.

Dada a particularidade do sistema brasileiro que abre a possibilidade do juiz optar por três regimes para cumprimento da pena, incluiremos esta variável em nosso modelo, além das duas variáveis utilizadas no caso americano.

O primeiro conjunto de modelos testará a hipótese de discriminação no sistema de justiça através de modelos de regressão linear para explicar as variações no tempo de condenação aplicado aos réus. Este tipo de regressão utiliza uma equação do tipo a) onde os valores $\beta_{n}$ são os coeficientes, os valores $X_{n}$ são os valores das variáveis e o valor $\varepsilon$ é a variação individual não explicada pelo modelo.

O segundo e o terceiro conjunto de modelos testarão através de regressões logísticas binominais qual a probabilidade de ocorrer uma condenação em função das variáveis utilizadas nas equações. O segundo utilizará como variável dependente a condenação do réu, o terceiro utilizará como variável dependente a condenação aos regimes fechado, semi-aberto, aberto contra a substituição, no caso de furto, e ao regime fechado contra os regimes semi-aberto, aberto ou sursis, no caso de roubo.

Estas regressões logísticas binárias têm a forma do tipo b) e calculam o logito da probabilidade de uma resposta positiva para a variável dependente do modelo. O logito é o logarítimo neperiano do logarítmo da probabilidade de um evento dividido pelo complementar desta probabilidade e os demais valores são os mesmos do modelo linear.

Os valores de $X_{n}$ serão os mesmos para os três conjuntos de modelos. Estes valores serão agrupados em três grupos. O primeiro grupo separa as variáveis que 
explicam características do réu, o segundo separa as variáveis processuais e o terceiro separa as variáveis de interação entre as variáveis do réu e do processo.

As equações são as seguintes:

a) $Y=\beta_{0}+\beta_{1} X_{1}+\beta_{2} X_{2}+\ldots+\beta_{n} X_{n}+\varepsilon$

b) $\operatorname{Ln}\left[\log \left(\frac{\pi}{1-\pi}\right)\right]=\beta_{0}+\beta_{1} X_{1}+\beta_{2} X_{2}+\ldots+\beta_{n} X_{n}+\varepsilon$

$Y$ : é uma variável linear com os meses de condenação;

$\operatorname{Ln}\left[\log \left(\frac{\pi}{1-\pi}\right)\right]$ : no caso das regressões do segundo conjunto de modelos, será calculado o logito da variável dependente condenação do réu (1), contra a absolvição (0). O terceiro conjunto utilizará como variável dependente a condenação aos regimes fechado, semi-aberto, aberto (1) contra a substituição(0), no caso de furto, e no caso de roubo aos regimes semiaberto, aberto ou sursis (0) contra o regime fechado (1);

$\beta_{0}$ : constante das equações;

$\varepsilon$ : erro da equação, a parcela da variação do indivíduo não explicada pelo modelo;

\section{Variáveis do réu}

$X_{1}$ : Variável réu homem: variável binária em que o valor 1 é homem e mede a influência do sexo do réu. Segundo o estudo de LIMA (2003), esta variável deve ter uma relação positiva com as variáveis dependentes e será aplicada somente aos modelos de furto, pois no caso de roubo ela é quase uma constante para réus homens;

$X_{2}$ : Variável réu branco: variável binária em que o valor 1 é cor branca, para medir a influência da variável cor. Pelos estudos de ADORNO (1989, 
1994, 1995, 1998 $\left.{ }^{a}, 1998^{b}, 2000\right)$ e de LIMA (2003), espera-se uma relação positiva entre esta variável e as variáveis dependentes;

$X_{3}$ : Variável menor que 25 anos: variável binária que controla o efeito apontado por CHIRICO e WALDO (1975). Segundo os resultados encontrados por STTEFENSMEIER (1999), espera-se que os réus mais jovens tenham penas maiores;

$X_{4}$ : Variável nordestinos: variável binária que controla 0 efeito de discriminação de réus de origem nordestina, apontada por ADORNO (1989, 1994, 1995, 1998 $\left.{ }^{a}, 1998^{b}, 2000\right)$ e BORDINI (1987). O resultado esperado é positivo entre esta variável e as dependentes;

$X_{5}$ : Variável estado civil do réu: variável binária que controla o efeito sobre réus casados. Alguns estudos de criminologia identificam uma associação entre criminosos e estado civil, com um número de criminosos menor entre os casados. Espera-se que a relação desta variável seja positiva;

$X_{6}$ : Variável escolaridade de segundo grau ou maior: variável binária que separa os réus com escolaridade maior ou igual ao segundo grau. $\mathrm{O}$ efeito esperado é que ela vá no sentido contrário às variáveis dependentes;

$X_{7}$ : Variável não economicamente ativo: separa os indivíduos que não são economicamente ativos. É uma proxy de ocupação e inclui além dos desocupados, os estudantes e as donas de casa. Pelo estudo de ADORNO $\left(1989,1994,1995,1998^{a}, 1998^{b}, 2000\right)$, o esperado é que esta variável tenha uma relação positiva com as variáveis dependentes. 


\section{Variáveis processuais}

$X_{8}$ : Variável mais de um réu: variável binária em que o valor 1 é o processo que tem mais de um réu. É uma proxy de concurso de pessoas, um dos agravantes do processo. É esperada uma relação positiva entre esta variável e as dependentes;

$X_{9}$ : Variável tipo qualificado: variável binária em que o valor 1 é o réu ter sido sentenciado ou denunciado em um tipo penal que acrescenta pena ao tipo padrão. O resultado esperado é positivo em relação às variáveis dependentes;

$X_{10}$ : Variável tentativa: variável binária em que o valor 1 é o réu ter sido sentenciado ou denunciado no artigo de tentativa (14, II), o que reduz a pena base aplicada. Para as variáveis dependentes meses de pena e regime espera-se uma relação inversa, para a variável condenação ele pode ter um efeito de proxy de flagrante, o que faz com que a chance de condenação aumente, como falamos na crítica ao trabalho de LIMA (2003). Com isto, no caso da condenação, espera-se uma relação positiva entre esta variável e as variáveis dependentes;

$X_{11}$ : Variável atenuante por idade: variável binária em que o valor 1 é o réu que tem o direito ao atenuante por idade, no caso, os réus menores de 21 anos e maiores de 70 anos. Espera-se que esta variável tenha efeito inverso às dependentes.

\section{Variáveis de interação}

Variáveis de interação entre as variáveis réus brancos e réus nordestinos com as variáveis processuais qualificado e tentativa, para controlar se porventura algum dos efeitos de variáveis sociais não é decorrente de 
uma distribuição desigual destes réus em alguma destas variáveis processuais.

Dentro de cada conjunto de regressões o primeiro modelo utilizará as variáveis do réu, as variáveis processuais e as variáveis de interação. O segundo modelo utilizará as variáveis do réu e as variáveis processuais, enquanto o terceiro modelo, apenas as variáveis do réu.

O segundo problema que abordaremos será a existência ou não de incentivos para o recurso, mensurando o comportamento dos atores envolvidos no processo para saber em quais casos há maior ou menor probabilidade do processo terminar na primeira instância ou ser recorrido.

Dado este quadro, elegemos como as variáveis dependentes do nosso quarto conjunto de modelos o recurso proposto pelo Ministério Público e o recurso proposto pelo réu. Para tanto, construiremos dois conjuntos de equações logísticas binominais para predizer a possibilidade do réu recorrer e, em outra equação, do Ministério Público recorrer. Estas equações incorporarão as variáveis processuais e sociais do banco de dados para tentar identificar em quais casos há um maior incentivo ao recurso destes atores. Esta etapa do trabalho é exploratória, logo, para as variáveis do réu não serão apontadas direções para as relações entre as variáveis. A equação utilizada é a seguinte:

$\operatorname{Ln}\left[\log \left(\frac{\pi}{1-\pi}\right)\right]=\beta_{0}+\beta_{1} X_{1}+\beta_{2} X_{2}+\ldots+\beta_{n} X_{n}+\varepsilon$, onde;

$\operatorname{Ln}\left[\log \left(\frac{\pi}{1-\pi}\right)\right]$ : no caso das regressões do quarto conjunto de modelos será calculado o Logito da variável dependente recurso do Ministério Público 
(1), contra a aceitação da sentença pelo Ministério Público (0), ou recurso do réu (1) contra a aceitação da sentença pelo réu (0);

$\beta_{0}$ : constante das equações;

ع: erro da equação, a parcela da variação do indivíduo não explicada pelo modelo;

\section{Variáveis do réu}

$X_{1}$ : Variável réu homem: variável binária em que o valor 1 é homem e mede a influência do sexo do réu. Segundo o estudo de LIMA (2003), esta variável deve ter uma relação positiva com as variáveis dependentes e será aplicada somente aos modelos de furto, pois no caso de roubo ela é quase uma constante para réus homens;

$X_{2}$ : Variável réu branco: variável binária em que o valor 1 é cor branca, para medir a influência da variável cor. Pelos estudos de ADORNO (1989, 1994, 1995, 1998 $\left.{ }^{a}, 1998^{b}, 2000\right)$ e de LIMA (2003), espera-se uma relação positiva entre esta variável e as variáveis dependentes;

$X_{3}$ : Variável menor que 25 anos: variável binária que controla o efeito apontado por CHIRICO e WALDO (1975). Segundo os resultados encontrados por STTEFENSMEIER (1999), espera-se que os réus mais jovens tenham penas maiores;

$X_{4}$ : Variável nordestinos: variável binária que controla o efeito de discriminação de réus de origem nordestina, apontada por ADORNO (1989, 1994, 1995, 1998 $\left.{ }^{\mathrm{a}}, 1998^{\mathrm{b}}, 2000\right)$ e BORDINI (1987). O resultado esperado é positivo entre esta variável e as dependentes;

$X_{5}$ : Variável estado civil do réu: variável binária que controla o efeito sobre réus casados. Alguns estudos de criminologia identificam uma associação 
entre criminosos e estado civil, com um número de criminosos menor entre os casados. Espera-se que a relação desta variável seja positiva;

$X_{6}$ : Variável escolaridade de segundo grau ou maior: variável binária que separa os réus com escolaridade maior ou igual ao segundo grau. O efeito esperado é que ela vá no sentido contrário às variáveis dependentes;

$X_{7}$ : Variável não economicamente ativo: separa os indivíduos que não são economicamente ativos. É uma proxy de ocupação e inclui além dos desocupados, os estudantes e as donas de casa. Pelo estudo de ADORNO $\left(1989,1994,1995,1998^{a}, 1998^{b}, 2000\right)$, o esperado é que esta variável tenha uma relação positiva com as variáveis dependentes.

\section{Variáveis processuais}

$X_{8}$ : Variável concordância na classificação da qualificadora na denúncia e na sentença: variável binária em que o valor 1 é se houve concordância entre a sentença e a denúncia e 0 se houve divergência. A relação esperada é contrária entre a concordância e a probabilidade de recurso;

$X_{9}$ : Variável concordância na classificação da tentativa na denúncia e na sentença: variável igual a anterior, só que para a tentativa. A relação esperada é contrária entre a concordância e a probabilidade de recurso;

$X_{10}$ : Variável meses de sentença: variável escalar com a quantidade de meses aos quais o réu foi sentenciado. Espera-se uma relação inversa no caso do recurso do MP e uma relação direta no caso do recurso do réu;

$X_{11}$ : Variável regime da sentença: variável binária em que o valor 1 significa condenação aos regimes fechado, semi-aberto, aberto contra a substituição (0), no caso de furto, e no caso de roubo aos regimes semi- 
aberto, aberto ou sursis (0) contra o regime fechado (1). Espera-se uma relação inversa no caso do recurso do MP, e uma relação direta no caso do recurso do réu.

Por fim, no último problema utilizaremos a técnica de comparação de médias de BONFERRONI para cruzar os perfis dos juízes com suas porcentagens de condenação, de regimes de pena, de recursos do réu e do Ministério Público para observar se há algum padrão de decisão que seja estimulado pela posição ideológica dos juízes.

O teste de BONFERRONI faz o cruzamento de todos os casos que selecionamos, bem como do valor médio do caso na linha. Ele subtrai a média do caso na coluna e, desta forma, é possível termos uma idéia da distância entre os casos e se esta distância é significante.

A técnica ideal neste caso seria a análise hierárquica de modelos não lineares com dois níveis. No primeiro nível, trabalharíamos com informações dos processos, incluindo informações do réu e de dados do processo, e no segundo nível teríamos informações dos juízes. No entanto, em virtude do baixo número de respostas no segundo nível, este tipo de análise não traria grandes ganhos com a comparação simples dos entrevistados, visto o número de respostas ser cinco. 


\section{4 - Exposição dos resultados}

\section{1 - 0 perfil da vítima}

A vítima foi classificada em duas variáveis. A primeira categoriza a vítima pela natureza e a segunda especifica o sexo das vítimas da categoria pessoa física. A variável natureza da vítima possui quatro categorias: vítimas pessoas físicas, pessoas jurídicas (englobando nesta categoria as pessoas jurídicas que desempenham atividade econômica), os órgãos públicos (incluindo escolas, hospitais e repartições públicas em geral) e outros (uma categoria residual que engloba pessoas jurídicas que não desempenham atividades econômicas, como condomínios, ONGs e clubes recreativos).

Analisando a tabela $\mathrm{X}$, vemos que a categoria que obtém resultados mais expressivos na distribuição para vara do processo de furto é a pessoa física. No total de processos que estão nos Departamentos de Inquérito Policia, ela responde por $49,7 \%$ dos casos, enquanto nos que foram direcionados para Varas Criminais, ela representa $65,3 \%$ dos casos. A hipótese que levantamos, mas que não é passível de comprovação estatística, é que esta categoria tem uma possibilidade maior de reconhecer o autor do delito do que as demais, e com isto, aumenta a possibilidade de identificação deste, bem como facilita a produção de provas que permitam melhor instruir o processo.

Por outro lado, a categoria de órgãos públicos tem comportamento inverso, respondendo por 13,3\% dos casos nos Departamentos de Inquérito Policia, mas só $1,1 \%$ dos casos de processos cujo mérito foi apreciado.

Para os casos de roubo, nota-se novamente que a categoria que obtém resultados mais expressivos na distribuição do processo para as varas é a pessoa 
física. No total de processos que estão nos Departamentos de Inquérito Policia, ela responde por $78,0 \%$ dos casos, ao passo que, nos que foram direcionados para varas criminais, ela representa $84,3 \%$ dos casos. Já a categoria de órgãos públicos não é tão relevante quanto a de furto, onde representava $13,3 \%$ dos casos nos Departamentos de Inquérito Policia. No caso de roubo ela constitui uma categoria residual.

Tabela X - Natureza da vítima dos processos no DIPO e nas varas criminais (em \%).

\begin{tabular}{l|ccc|ccc}
\hline \multicolumn{1}{c|}{ Natureza da Vítima } & \multicolumn{3}{c}{ Furto } & \multicolumn{3}{c}{ Roubo } \\
& DIPO & Varas & Total & DIPO & Varas & Total \\
\hline Pessoa Física & 49,7 & 65,3 & 59,3 & 78,0 & 84,3 & 82,4 \\
Pessoa jurídica & 35,4 & 32,4 & 33,5 & 19,7 & 14,8 & 16,3 \\
Órgãos públicos & 13,3 & 1,1 & 5,8 & 1,7 & 0,1 & 0,6 \\
Outros & 1,7 & 1,2 & 1,4 & 0,6 & 0,8 & 0,7 \\
\hline & $\mathbf{8 8 8}$ & $\mathbf{1 4 0 5}$ & $\mathbf{2 2 9 3}$ & $\mathbf{8 7 3}$ & $\mathbf{1 9 3 3}$ & $\mathbf{2 8 0 6}$ \\
\hline
\end{tabular}

Com $99 \%$ de confiança, pelo teste $\chi^{2}\left(\chi^{2}=162,4 ; 3 \mathrm{gl}\right)$, rejeitamos a hipótese nula e aceitamos a hipótese alternativa de associação entre a natureza da vítima e a localização do processo no Departamentos de Inquérito Policia ou na vara criminal. A intensidade desta associação é média, segundo o teste $V$ de Cramer, apresentando o valor de 26,6 \%. Analisando o resíduo ajustado e padronizado desta distribuição vemos que há uma diferença significativa para a categoria pessoa física e órgãos públicos. As pessoas físicas apresentam um número maior de casos do que seria esperado se a distribuição fosse aleatória (respectivamente 7,4 e -12,1).

No caso de roubo, com $99 \%$ de confiança com o teste $\chi^{2}\left(\chi^{2}=38,0 ; 3 \mathrm{gl}\right)$, rejeitamos a hipótese nula e aceitamos a hipótese alternativa de associação entre a natureza da vítima e a localização do processo no Departamentos de Inquérito Policia ou na vara. A intensidade desta associação é média, segundo o teste $V$ de Cramer, apresentando o valor de 11,6\%. 
Fazendo a análise dos resíduos ajustados e padronizados encontramos diferenças significativas nas categorias pessoa física e pessoa jurídica (respectivamente com valores de 4,1 e 3,3).

Já o sexo da vítima não é determinante no curso do processo de furto, pelo teste $\chi^{2},\left(\chi^{2}=1,86 ; 1 \mathrm{gl}\right)$, com $95 \%$ de confiança, não podemos rejeitar a hipótese nula de independência entre as duas variáveis sexo da vítima e a localização do processo no Departamentos de Inquérito Policia ou na vara.

Ao contrário do que ocorre no furto, o sexo da vítima apresenta resultados diferentes quanto ao curso do processo de roubo. Com $99 \%$ de confiança com o teste $\chi^{2}\left(\chi^{2}=30,6 ; 1 \mathrm{gl}\right)$, rejeitamos a hipótese nula e aceitamos a hipótese alternativa de associação entre a natureza da vítima e a localização do processo no Departamentos de Inquérito Policia ou na vara. A intensidade desta associação é fraca, segundo o teste $V$ de Cramer, apresentando o valor de 11,6\%.

Tabela XI - Sexo da vítima pessoa física dos processos no DIPO e nas varas criminais (em \%).

\begin{tabular}{l|ccc|ccc}
\hline \multicolumn{1}{c|}{ Sexo da Vítima } & \multicolumn{3}{c|}{ Furto } & \multicolumn{3}{c}{ Roubo } \\
& DIPO & Varas & Total & DIPO & Varas & Total \\
\hline Masculino & 62,8 & 66,6 & 65,3 & 84,0 & 73,3 & 76,5 \\
Feminino & 37,2 & 33,4 & 34,7 & 16,0 & 26,7 & 23,5 \\
\hline & $\mathbf{4 3 8}$ & $\mathbf{9 1 5}$ & $\mathbf{1 3 5 3}$ & $\mathbf{6 8 1}$ & $\mathbf{1 6 1 2}$ & $\mathbf{2 2 9 3}$ \\
\hline
\end{tabular}

\section{2 - O perfil do réu}

Os dados sobre o perfil do réu foram extraídos das fichas de andamento dos processos, disponíveis pelo sistema de dados do Tribunal de Justiça. Os dados referem-se apenas aos processos que foram distribuídos para as varas criminais no ano de 2002, na comarca de São Paulo. Os processos que se encontram nos 
DIPOS (Departamentos de Inquérito Policial) não serão objeto desta análise, uma vez que os dados referentes a estes não estão disponíveis.

O sexo do réu de furto é predominantemente masculino. Esta categoria engloba $85,1 \%$ do total de indivíduos, com predominância ainda mais intensa no caso de roubo, onde os réus masculinos respondem por $96,8 \%$ dos processos.

Tabela XII - Sexo do réu (em \%).

\begin{tabular}{lcc}
\hline Sexo do Réu & Furto & Roubo \\
\hline Masculino & 85,1 & 96,8 \\
Feminino & 14,9 & 3,2 \\
\hline Total & $\mathbf{1 9 3 2}$ & $\mathbf{2 7 2 7}$ \\
\hline
\end{tabular}

O estado civil do réu aponta uma predominância de solteiros, com 80,6\% dos casos de furto e $85,8 \%$ dos casos de roubo. Analisando a associação entre tipo penal e estado civil temos uma associação significante a 0,01 $\left(X^{2}=45,6, g l=4\right)$. A intensidade da associação é fraca com $\mathrm{V}$ de Cramer de 10\%. Analisando os resíduos, com $99 \%$ de confiança há uma diferença significativa com mais casos de casados e viúvos em furto e de solteiros, em roubo. As categorias divorciado e outros não apresentam diferenças significativas com relação à distribuição marginal. Os valores encontrados foram, respectivamente, 4,8 e 4,1 para casados e viúvos e 4,5 para solteiros. A taxa de não resposta foi de 7,7 \% para furto e $7 \%$ para roubo.

Tabela XIII - Estado Civil do réu (em \%).

\begin{tabular}{lcc}
\hline Estado civil do Réu & Furto & Roubo \\
\hline Solteiro & 80,6 & 85,8 \\
Casado & 15,0 & 10,1 \\
Divorciado & 2,1 & 1,7 \\
Viúvo & 1,2 & 0,2 \\
Outros & 1,2 & 2,2 \\
\hline Total & $\mathbf{1 7 0 2}$ & $\mathbf{2 5 1 7}$ \\
\hline
\end{tabular}


A ocupação dos réus não permitiu um detalhamento muito grande visto que a classificação do poder judiciário diferiu da do IBGE, comumente utilizada neste tipo de análise. A classificação que fizemos para testar a proposição de ADORNO (1989, 1994, 1995, 1998 $\left., 1998^{b}, 2000\right)$ de réus desocupados foi agrupar as categorias Economicamente ativas e Não economicamente ativas, uma das únicas agregações possíveis de aproximar ambas as classificações. Na categoria Não economicamente ativa foram incluídas as donas de casa, estudantes, desocupados e desempregados, sendo as demais incluídas em Economicamente ativas. A taxa de não resposta foi de $10,1 \%$ para furto e $10,3 \%$ para roubo, e a associação entre o tipo penal e a ocupação foi, com $99 \%$ de confiança, significante $\left(X^{2}=6,844 ; g l=1\right)$. A população não economicamente ativa é maior em roubo do que em furto, mas esta associação é bem fraca, segundo o teste $\mathrm{V}$ de Cramer é de $4,1 \%$.

Tabela XIV - Ocupação do réu (em \%).

\begin{tabular}{lcc}
\hline Ocupação do Réu & Furto & Roubo \\
\hline Economicamente Ativa & 69,5 & 65,6 \\
Não economicamente ativa & 30,5 & 34,4 \\
\hline Total & $\mathbf{1 6 5 7}$ & $\mathbf{2 4 2 8}$ \\
\hline
\end{tabular}

Quanto à cor da pele, que considera o registro do processo, no caso de furto os indivíduos são em maior número brancos, com 59,5 \% dos casos válidos, seguido por pardos, com 29,5 \%, e por negros, com 10,6 \%; as demais populações são irrelevantes. O total de casos nos quais não constava informação foi de $13,3 \%$. Quanto ao roubo, os brancos são $51,4 \%$ dos casos válidos, seguido por pardos, com $36,7 \%$, e por negros, com $11,6 \%$; as demais populações são irrelevantes. 0 total de casos nos quais não constava informação foi de $7,8 \%$. 
Tabela XV - Cor do réu (em \%).

\begin{tabular}{lcc}
\hline Cor do Réu & Furto & Roubo \\
\hline Branco & 59,5 & 51,4 \\
Pardo & 29,5 & 36,7 \\
Negro & 10,6 & 11,6 \\
Amarelo / Vermelho & 0,5 & 0,3 \\
\hline Total & $\mathbf{1 6 7 6}$ & $\mathbf{2 5 1 3}$ \\
\hline
\end{tabular}

Cruzando o sexo com a cor do réu, observamos que as mulheres negras e pardas constituem uma categoria residual no processo de roubo, e a discriminação apontada por LIMA (2003) para este grupo pode ser fruto muito mais do pequeno número de casos que esta categoria representa ao longo do processo, sofrendo um impacto muito maior de casos individuais do que as grandes categorias, como é o caso dos homens. Esta categoria não representa nem 1,5\% do total de casos e, portanto, está sujeito a uma flutuação muito maior em função de variações individuais. Da mesma forma, o sistema pode estar operando informalmente em etapas anteriores e só levando aos tribunais os casos graves, o que repercutiria no resultado encontrado.

Tabela XVI - Sexo e cor do réu para os diferentes tipos penais (em \%).

\begin{tabular}{lcccc}
\hline & \multicolumn{2}{c}{ Furto } & \multicolumn{2}{c}{ Roubo } \\
& Branco & Negro/Pardo & Branco & Negro/Pardo \\
\hline Masculino & 85,0 & 86,0 & 96,6 & 96,8 \\
Feminino & 15,0 & 14,0 & 3,4 & 3,2 \\
\hline Total & $\mathbf{9 9 8}$ & $\mathbf{6 7 2}$ & $\mathbf{1 2 9 1}$ & $\mathbf{1 2 1 3}$ \\
\hline
\end{tabular}

A distribuição etária dos réus homens se aproxima da distribuição normal, porém apresenta-se distorcida em função de uma característica do processo, que limita este universo aos maiores de dezoito anos. As mulheres também apresentam uma distribuição próxima da distribuição normal, igualmente distorcida em função da idade mínima de 18 anos. 
Quanto à média de idade dos réus, a cor não é significativamente importante para diferenciar os grupos, pois se considerarmos uma significância de $5 \%$ os intervalos se sobrepõem. O gênero, pelo contrário, é importante para diferenciar a média de idade dos réus do tipo penal furto, sendo que a média de idade das mulheres, com $95 \%$ de confiança, é maior do que a média de idade dos homens. Para o tipo penal roubo, em função do baixo número de mulheres que respondem a processo, os intervalos de confiança se sobrepõem, então não podemos afirmar que estes grupos sejam significativamente diferentes.

Quanto à diferença entre os tipos penais, os réus de furto, com $95 \%$ de confiança, são mais velhos do que os réus de roubo, embora esta diferença de idade não seja tão grande. A média dos réus de roubo fica em 24 anos e a dos réus de furto em 28 anos.

Tabela XVII - Idade dos réus na data do registro do fato, por sexo e cor.

\begin{tabular}{l|cccc|cccc}
\hline & \multicolumn{4}{c}{ Hurto } & \multicolumn{3}{c}{ Roubo } \\
\hline & \multicolumn{2}{|c}{ Homens } & \multicolumn{2}{c}{ Mulheres } & \multicolumn{2}{c}{ Homens } & \multicolumn{2}{c}{ Mulheres } \\
\hline & Brancos & Pardos & Brancos & Pardos & Brancos & Pardos & Brancos & Pardos \\
& & Negros & & Negros & & Negros & Negros \\
\hline Média & 27,64 & 26,37 & 30,35 & 29,82 & 24,34 & 23,93 & 26,05 & 26,67 \\
Mediana & 25,00 & 24,00 & 28,50 & 28,00 & 22,00 & 22,00 & 24,00 & 24,00 \\
Desv. Padrão & 9,26 & 8,11 & 9,82 & 9,27 & 6,11 & 6,21 & 7,79 & 8,31 \\
Mínimo & 18 & 18 & 18 & 18 & 18 & 18 & 18 & 18 \\
Máximo & 73 & 65 & 73 & 69 & 62 & 60 & 52 & 49 \\
Skewness & 1,42 & 1,47 & 1,09 & 1,14 & 1,57 & 1,65 & 1,60 & 1,01 \\
Kurtosis & 2,02 & 2,44 & 1,59 & 2,55 & 3,18 & 3,26 & 2,75 & 0,13 \\
N & 845 & 572 & 150 & 92 & 1241 & 1170 & 43 & 39 \\
T mínimo & 27,01 & 25,70 & 28,76 & 27,90 & 24,00 & 23,57 & 23,65 & 23,97 \\
T máximo & 28,26 & 27,03 & 31,93 & 31,73 & 24,68 & 24,29 & 28,44 & 29,36 \\
\hline
\end{tabular}

A maior parte dos réus de furto e de roubo são originários do Brasil, da Região Metropolitana de São Paulo, respondendo por $64,6 \%$ dos casos válidos de furto e por $69,4 \%$ dos casos válidos de roubo. A segunda categoria a ser destacada 
é a dos réus de origem de Estados do nordeste, que respondem por $21,1 \%$ dos casos válidos de furto e 19,4 \% dos casos válidos de roubo. As demais categorias não apresentam nenhum grande destaque. Os réus estrangeiros também são insignificantes, só ocorrendo uma pequena concentração de peruanos, mas que não chegam a $1 \%$ da amostra de furto (13 casos). Os casos sem informação são $6,8 \%$.

Tabela XVIII - Naturalidade do réu (em \%).

\begin{tabular}{lcc}
\hline \multicolumn{1}{c}{ Naturalidade do Réu } & Furto & Roubo \\
\hline Cidade de São Paulo & 57,3 & 63,0 \\
Estados da Região Nordeste & 20,8 & 18,1 \\
Grande São Paulo & 6,4 & 7,7 \\
Outros municípios do Estado & 5,2 & 5,1 \\
Outros Estados do Sudeste & 4,7 & 3,5 \\
Região Sul & 3,1 & 1,6 \\
Outras Regiões & 1,3 & 0,9 \\
Outros países & 1,2 & 0,1 \\
\hline \multicolumn{1}{c}{ Total } & $\mathbf{1 7 8 1}$ & $\mathbf{2 6 4 9}$ \\
\hline
\end{tabular}

A escolaridade dos réus também é muito baixa, sendo que $78,9 \%$ dos de furto e $84,9 \%$ dos de roubo apresentam no máximo o primeiro grau completo. $\mathrm{O}$ número de réus com superior completo ou incompleto não chega à $2,5 \%$ do total de casos de furto e de $0,5 \%$ dos casos de roubo. Os casos sem informação são elevados e chegam a $27,5 \%$ da amostra de furto e $19,2 \%$ da amostra de roubo.

Esta escolaridade está associada à cor. Agrupando as categorias de segundo grau e superior e procedendo aos testes estatísticos, com 99\% de confiança do teste Chi Quadrado, não podemos rejeitar a hipótese nula e aceitamos a hipótese alternativa de associação entre estas duas variáveis tanto para furto quanto para roubo (respectivamente $\chi^{2}=19,442 ; \mathrm{gl}=2$; e $\chi^{2}=34,439 ; \mathrm{gl}=2$ ). $\mathrm{A}$ intensidade desta associação em ambos os casos é fraca, como aponta o teste $V$ de Cramer, ficando em $11,9 \%$ para furto e $12,6 \%$ para o roubo. Analisando o resíduo 
padronizado e ajustado vemos que há significativamente mais réus brancos nas categorias de alta escolaridade do que réus negros, enquanto que na categoria de até $1^{\circ}$ grau incompleto há mais réus negros do que seria esperado. Para a categoria de $1^{\circ}$ grau completo a diferença não é significante (respectivamente 4,3 e 3,0 para furto e 5,5 e 4,4 para roubo).

Tabela XIX - Escolaridade do réu por cor (em \%).

\begin{tabular}{lcccccc}
\hline \multicolumn{1}{c}{ Escolaridade do Réu } & \multicolumn{2}{c}{ Furto } & \multicolumn{3}{c}{ Roubo } \\
& Branco & Pardo / Negro & Total & Branco & Pardo / Negro & Total \\
\hline Até $\mathbf{1}^{\mathbf{0}}$ grau incompleto & 46,6 & 54,7 & 49,8 & 50,9 & 60,3 & 55,4 \\
$\mathbf{1}^{\mathbf{0}}$ grau completo & 28,8 & 30,3 & 29,4 & 29,9 & 29,0 & 29,4 \\
$\mathbf{2}^{\mathbf{0}}$ grau ou mais & 24,7 & 15,0 & 20,8 & 19,2 & 10,8 & 15,1 \\
\hline Total & $\mathbf{8 3 1}$ & $\mathbf{5 5 2}$ & $\mathbf{1 3 8 3}$ & $\mathbf{1 1 1 8}$ & $\mathbf{1 0 5 0}$ & $\mathbf{2 1 6 8}$ \\
\hline
\end{tabular}

Dado este perfil do réu de furto, no nosso modelo desprezaremos a variável gênero para o tipo penal roubo, pois ela praticamente só apresenta um valor, o gênero masculino. Em virtude da pequena quantidade de mulheres, não podemos realizar testes estatísticos generalizáveis para elas.

\section{3 - O perfil dos juízes}

Como já afirmamos, este tópico foi prejudicado na pesquisa em virtude da baixo número de respostas aos questionários. As características deste grupo só permitiram identificar a ocorrência de casos antagônicos e que componham tipos diversos de comportamento para que possamos fazer uma análise qualitativa destas respostas.

Os resultados aqui expostos não são generalizáveis para a população de juízes da comarca de São Paulo, nem tampouco constituem uma amostra representativa deste universo. Não será possível a realização de nenhum teste estatístico para aferir a significância das associações. Estas respostas fornecerão 
apenas um material indicativo das condutas possíveis dos juízes e, por outro lado, se o questionário é eficaz para captar diferenças entre os entrevistados. Posteriormente esses dados fornecerão subsídios para explorar e pré-testar o modelo e conferir se, nestes casos, ele está predizendo corretamente os resultados que seriam esperados segundo o que está exposto na literatura.

O único dado disponível para todos os juízes é o tempo de ingresso na magistratura e na entrância. Todos os juízes estão há mais de dois anos na entrância, esse seria o período de adaptação das decisões, segundo WOOD (1998). Face a isto, torna-se inviável contemplar esta característica já que ela constitui uma constante neste universo.

O número total de respostas foram cinco. Embora seja um número pequeno, elas contemplaram juízes com posições distintas, o que permite uma certa comparação qualitativa dos comportamentos.

Estes juízes apresentam uma média de idade em torno de 43 anos, não tendo mais de dez anos de diferença entre o juiz mais novo e o juiz mais velho, o que indica um grupo homogêneo nesta característica. Já o estado civil dos juízes é uma variável que os divide em dois grupos, com um leve predomínio dos casados com três casos, contra os solteiros com dois.

A variável escolaridade dos pais revela um grupo heterogêneo: um caso de juiz que possui pais analfabetos, passando por um caso de pais com nível intermediário de educação e dois juízes com pais de nível educacional elevado. Esta diversidade é importante para testar a hipótese levantada por GREENBERG (1977) de que a ascensão de juízes proveniente de baixo status seria importante para a mudança dos padrões de julgamento. Como proxy de baixo status utilizaremos a 
variável educação dos pais para dividir os grupos e verificar se estes juízes julgam de forma distinta.

A variável profissão dos pais também revela um grupo heterogêneo, só que esta informação é prejudicada pela resposta aposentado, não permitindo identificar a origem de um dos casos. Igualmente dois juízes provêm de famílias onde só o chefe da família trabalha; outros dois provêm de famílias com pais profissionais liberais.

A formação destes juízes é igualmente heterogênea, reunindo desde juízes que se formaram nos cursos mais tradicionais (PUC e Mackenzie) até os formados em faculdades do interior e da Região Metropolitana de São Paulo. Esta variedade pode ser utilizada para verificar se há divergências ideológicas que poderiam ser atribuídas à formação acadêmica.

Quanto ao ano de formação, apenas um dos entrevistados se bacharelou após a promulgação da Constituição de 1988 e da reforma penal de 1984. A adaptação a esta nova legislação foi feita posteriormente à formação acadêmica.

A formação em outros cursos também revela um grupo heterogêneo, com dois dos casos se especializando e cursando pós-graduação em Direito, e três terminando a formação acadêmica no curso de Direito.

A experiência anterior dos juízes também é heterogênea, com um dos casos ingressando direto na magistratura, dois tendo trabalhado em cargos inferiores da hierarquia do poder judiciário, e dois tendo trabalhado como advogado antes de ingressar na magistratura. Apenas um dos entrevistados passou a maior parte da carreira fora da magistratura, trabalhando por 15 anos antes de ingressar na magistratura. Os demais ingressaram, em média 6,5 anos após formados, e um dos casos teve na magistratura o primeiro emprego. 
A maior parte dos entrevistados não tinha parentes no meio jurídico: um deles tinha parentes nas profissões hierarquicamente inferiores e outro tinha parentes na magistratura.

Quanto à preferência por partidos políticos, todos os entrevistados responderam que não tinham preferência. Esta resposta pode ter sido influenciada pelo momento político em que foi aplicado o questionário - nos meses de janeiro e fevereiro de 2006, no momento em que a imagem dos partidos políticos se encontrava abalada por denúncias de corrupção. No que se refere ao autoposicionamento ideológico, dois se declararam de centro-esquerda, um de centro e um de direita.

As questões referentes às diferentes posições frente ao direito, em geral, não dividiram os entrevistados. Em duas das questões houve consenso e em outra os juízes se posicionaram pela aceitação ou indiferença frente às proposições formuladas. A única questão que os dividiu foi a que propôs que o judiciário tenha um papel ativo: uma das respostas concordou com a afirmação, três discordaram e uma ficou indiferente. Pode ter ocorrido um problema com as questões utilizadas para captar esta divisão proposta pela literatura, ou neste ramo do direito esta divisão não é importante e não desperta um debate entre estes juízes.

Quanto ao conjunto de questões específicas do direito penal, estas apresentaram uma divisão maior, com algumas respostas mais duras e outras mais brandas frente à aplicação das leis. A única resposta que não dividiu os entrevistados foi a da aplicação do princípio do direito penal mínimo. Nos demais pontos há uma variação de respostas que permite diferenciar os juízes de acordo com o seu grau de rigidez frente ao direito penal. 
Analisando estes dados temos cinco perfis de juízes diferentes e só consideramos aquelas características que dividem o grupo. Quanto à posição normativista ou decisionista do direito, consideramos apenas a posição na questão do papel ativo do judiciário, pois nas demais as respostas foram homogêneas. Classificamos os juízes em primeiro lugar pela posição mais rígida segundo as respostas sobre direito penal. Como tinham dois padrões de respostas parecidos, provocamos o desempate pela resposta à questão da aplicação do direito penal mínimo, a questão mais claramente ideológica dentre o conjunto de questões. Tendo por base esta classificação, esta escala classifica os juízes progressivamente dos mais brandos aos mais rígidos.

O primeiro é casado, ascendeu socialmente, não tem experiência profissional anterior, vem de curso tradicional, formado depois de 1988, é de direita, tem posição normativista e é o primeiro na rigidez na aplicação do direito penal.

O segundo é casado, ascendeu socialmente, é formado em curso tradicional, tem experiência anterior, formou-se antes de 1988, é de centro, tem posição decisionista e é mediano na aplicação do direito penal

O terceiro é casado, ascendeu socialmente, tem longa experiência profissional anterior, formado em curso não tradicional, fez pós-graduação, é formado antes de 1988, é de centro-esquerda, tem posição normativista e é brando na aplicação do direito penal.

O quarto é solteiro, manteve o status social, tem curta experiência anterior, formou-se em curso não tradicional antes de 1988, não se manifestou sobre a posição política, tem posição normativista e é brando na aplicação do direito penal.

O último é solteiro, manteve o status social, tem experiência anterior, vem de curso tradicional, fez pós-graduação, é formado antes de 1988, é de centro 
esquerda, é indiferente entre a posição normativista e a decisionista, e é o mais brando na aplicação do direito penal.

\section{4 - As características do processo}

Analisando os processos da primeira instância, vemos que a maior parte dos casos de furto tem a solução nesta instância, onde 85,7 \% dos casos são resolvidos por meio da suspensão, arquivamento, transação, extinção ou por sentença aceita por ambas as partes. Apenas 14,3 \% dos processos deste tipo penal são recorridos e, neste percentual, a maior parte é por iniciativa do réu. No caso de roubo, quase a metade dos processos é recorrida, sendo que a maior parte destes recursos é por iniciativa da defesa. As decisões de absolvição recorridas, que na pesquisa do CEBEPEJ (WATANABE, 2001) apresentavam os maiores índices de revisão são minoria dentre o total de casos julgados. O total deste tipo de recurso, se considerarmos a soma dos casos em que só o MP recorre e dos casos em que ambas as partes recorrem, chega ao total de $10,8 \%$. O total de não respostas para as variáveis foi de, respectivamente, $13,7 \%$ e $11,6 \%$.

Tabela XX - Resultado do processo (em \%).

\begin{tabular}{lcc}
\hline \multicolumn{1}{c}{ Resultado } & Furto & Roubo \\
\hline Suspensão, Arquivamento, Transação, ou Extinção & 29,9 & 3,1 \\
Decisão sem recurso & 55,8 & 45,2 \\
Réu recorreu & 12,4 & 41,9 \\
MP recorreu & 1,3 & 4,5 \\
Ambos recorreram & 0,6 & 5,3 \\
\hline Total & $\mathbf{1 5 8 9}$ & $\mathbf{2 3 9 6}$ \\
\hline
\end{tabular}

Nos processos de furto e de roubo, a maior parte dos réus são denunciados em artigos que acrescentam tempo à pena base. No caso de furto, o total de denúncias incidentes nestes artigos é de 69,7 \%. Já para roubo, 89,9\% das 
denúncias são de crimes em tipos penais acrescidos em relação à pena base e as não respostas foram de, respectivamente, $5,9 \%$ e $6,4 \%$ dos casos sendo que, quando condenados, esta proporção não se altera significativamente. O total de sentenciados por furto com penas aumentadas é de $67,8 \%$ e para roubo $87,2 \%$.

Tabela XXI - Pena aumentada (art 155, $\left.\S 1^{\circ}, \S 4^{\circ}, 157 \S 2^{\circ}, \S^{\circ}\right)(\mathrm{em} \%)$

\begin{tabular}{lcccc}
\hline \multicolumn{1}{c}{ Aumentada } & Denúncia & \multicolumn{2}{c}{ Sentença } \\
& Furto & Roubo & Furto & Roubo \\
\hline Sim & 69,7 & 89,9 & 67,8 & 87,2 \\
Não & 30,3 & 10,1 & 32,2 & 12,8 \\
\hline Total & $\mathbf{1 7 3 5}$ & $\mathbf{2 5 3 4}$ & $\mathbf{9 5 1}$ & $\mathbf{1 9 0 2}$ \\
\hline
\end{tabular}

No caso de roubo, em $70,8 \%$ dos casos os réus foram denunciados com o agravante de terem empregado armas no momento do crime e esta proporção cai na sentença, onde $63,7 \%$ dos réus tem este agravante.

Tabela XXII - Emprego de arma (em \%).

\begin{tabular}{lcc}
\hline Emprego de arma & $\begin{array}{c}\text { Denúncia } \\
\text { Roubo }\end{array}$ & $\begin{array}{c}\text { Sentença } \\
\text { Roubo }\end{array}$ \\
\hline Sim & 70,8 & 63,7 \\
Não & 29,2 & 36,3 \\
\hline Total & $\mathbf{2 5 3 4}$ & $\mathbf{1 9 0 2}$ \\
\hline
\end{tabular}

Em $46,7 \%$ dos casos de furto os réus foram denunciados também como incidentes no artigo de tentativa, sendo este índice de apenas $18 \%$ nos casos de roubo. Quando da sentença a proporção se mantém com 49,3\% dos réus de furto e $21,7 \%$ dos réus de roubo, recebendo a pena com base neste artigo.

Tabela XXIII - Tentativa (art. 14, inciso II) (em \%).

\begin{tabular}{lcccc} 
& Aumentada & \multicolumn{2}{c}{ Denúncia } & \multicolumn{2}{c}{ Sentença } \\
& Furto & Roubo & Furto & Roubo \\
\hline Sim & 46,7 & 18,0 & 49,3 & 21,7 \\
Não & 53,3 & 82,0 & 50,7 & 78,3 \\
\hline Total & $\mathbf{1 7 3 5}$ & $\mathbf{2 5 3 4}$ & $\mathbf{9 5 1}$ & $\mathbf{1 9 0 2}$ \\
\hline
\end{tabular}


A sentença predominante de furto é a condenação, em $57,7 \%$ dos casos, seguida pela suspensão, o arquivamento, a transação ou a extinção, em 30,9 \% dos casos. No caso de roubo este percentual sobe para $83 \%$ em virtude, sobretudo, da impossibilidade processual de suspender o processo. Em ambos os tipos penais a taxa de absolvição é parecida, sendo de $11,4 \%$ para furto e de $13,4 \%$ para roubo. A taxa de não resposta é de $13,2 \%$ para furto e de $11,4 \%$ para roubo.

Tabela XXIV - Resultado do processo (em \%).

\begin{tabular}{lcc}
\hline \multicolumn{1}{c}{ Resultado } & Furto & Roubo \\
\hline Suspensão, Arquivamento, Transação, ou Extinção & 30,9 & 3,7 \\
Condenação & 57,7 & 83,0 \\
Absolvição & 11,4 & 13,4 \\
\hline Total & $\mathbf{1 6 0 0}$ & $\mathbf{2 3 9 6}$ \\
\hline
\end{tabular}

O regime de condenação predominante para furto é o aberto, respondendo por $56,2 \%$ dos casos. As condenações ao regime fechado também são expressivas, respondendo por $29,4 \%$ dos casos. Quanto ao roubo, o regime predominante é o fechado com $83,5 \%$ dos casos. Os condenados por roubo direcionados ao regime aberto representam apenas $5,0 \%$ dos casos. O regime semi-aberto é similar em ambos, ficando em $9,8 \%$ para furto e $11,2 \%$ para roubo. A porcentagem de não resposta é, respectivamente, de $13,9 \%$ e $12,0 \%$.

Tabela XXV - Regime da pena (em \%).

\begin{tabular}{lcc}
\hline \multicolumn{1}{c}{ Resultado } & Furto & Roubo \\
\hline Aberto & 56,2 & 5,0 \\
Semi-aberto & 9,8 & 11,2 \\
Fechado & 29,4 & 83,5 \\
Multa & 4,6 & 0,3 \\
\hline Total & $\mathbf{9 1 1}$ & $\mathbf{1 9 7 4}$ \\
\hline
\end{tabular}

A multa acompanha a privação da liberdade na grande maioria dos casos de condenação. Das condenações de furto, $54,8 \%$ das sentenças condenatórias foram 
substituídas por sentenças alternativas. A pena alternativa preferida é a prestação de serviços à comunidade que, em geral, é empregada concomitantemente à outra pena substitutiva. As outras possibilidades de substituição são pouco empregadas.

O sursis continua a ser empregado, embora em um número bem restrito de casos, quando não é possível a substituição por penas alternativas. Em geral a sua aplicação é condicionada ao cumprimento de alguma obrigação alternativa, como a prestação de serviços à comunidade, o que é uma expansão das possibilidades da aplicação da substituição de condenação por este mecanismo. No caso de furto ele representou $6,4 \%$ das penas impostas nas condenações e no caso de roubo, 1,3 \%.

Tabela XXVI - Penas substitutivas (em \%)

\begin{tabular}{lc}
\hline \multicolumn{1}{c}{ Pena } & Furto \\
\hline Prestação de serviços à comunidade & 19,7 \\
Prestação de serviços à comunidade/Multa & 12,1 \\
Prestação de serviços à comunidade/Prestação pecuniária & 6,4 \\
Prestação de serviços à comunidade/Interdição de direitos & 0,4 \\
Prestação de serviços à comunidade/Limitação fim de semana & 3,3 \\
Prestação Pecuniária & 1,8 \\
Prestação Pecuniária e Multa & 0,8 \\
Interdição temporária de direitos e Multa & 0,1 \\
Interdição temporária de direitos & 0,2 \\
Multa & 3,3 \\
Sursis & 6,7 \\
CONDENAÇÃO NÃO SUBSTITUíDA & 45,2 \\
\hline Total & 951 \\
\hline
\end{tabular}

Quanto ao número de réus, $61,9 \%$ dos processos de furto apresentam um único réu e este percentual cai para $51,5 \%$ no caso dos processos de roubo.

Tabela XXVII - Número de réus (em \%)

\begin{tabular}{lcc}
\hline & Furto & Roubo \\
\hline 1 réu & 61,9 & 51,5 \\
Mais de 1 réu & 38,1 & 48,5 \\
\hline Total & $\mathbf{1 8 4 4}$ & $\mathbf{2 7 0 7}$ \\
\hline
\end{tabular}


Esta variável foi criada para tentar medir uma variação processual, o concurso de pessoas. Como não temos esta informação nos dados que dispomos do processo, utilizamos o número de réus como uma proxy. 


\section{5 - Análise dos modelos}

Testando o impacto da variável cor para explicar os meses de sentença, através do teste ANOVA, a variável não se mostrou significante para explicar a quantidade de meses da sentença de furto e de roubo. Desprezando o teste de significância e examinando apenas a diferença entre as populações, ainda assim esta diferença apresenta sentido contrário do que afirmam os trabalhos da literatura nacional, uma vez que o tempo médio de condenação da amostra da população branca é significativamente maior do que o tempo médio de condenação da amostra da população negra e parda.

Tabela XXVIII - Média e desvio padrão do tempo de sentença em meses em função da cor do réu.

\begin{tabular}{lcccc}
\hline & \multicolumn{2}{c}{ Furto } & \multicolumn{2}{c}{ Roubo } \\
& Branco & Negro/Pardo & Branco & Negro/Pardo \\
\hline Média & 18,70 & 18,49 & 84,60 & 81,86 \\
Desvio Padrão & 12,28 & 12,19 & 134,66 & 113,51 \\
\hline
\end{tabular}

O teste da ANOVA aponta também que a maior parte da variância no tempo de sentença é dada, em ambos os casos, por características individuais e não por uma característica atribuída à variável cor. A parcela da variância explicada por esta variável é desprezível frente à variância atribuída a características dos indivíduos.

Tabela XXIX - Teste ANOVA para variação da sentença em meses em função da cor do réu.

\begin{tabular}{llccccc}
\hline Tipo Penal & \multicolumn{1}{c}{ Fonte } & $\sum$ dos quadrados & $\begin{array}{c}\text { Gl de } \\
\text { liberdade }\end{array}$ & $\begin{array}{c}\text { Média dos } \\
\text { quadrados }\end{array}$ & Razão F & Significância \\
\hline \multirow{3}{*}{ Furto } & Entre grupos & 9,99 & 1 & 9,993 & 0,07 & 0,80 \\
& Intra grupos & 131188,34 & 876 & 149,758 & & \\
& Total & 131198,33 & 877 & & 0,64 \\
\multirow{2}{*}{ Roubo } & Entre grupos & 3411,46 & 1 & 3411,46 & & 0,22 \\
& Intra grupos & 28167656,00 & 1818 & 15493,76 & & \\
\hline
\end{tabular}


Analisando a média das sentenças por varas, não podemos afirmar que, sistemicamente, haja uma discriminação no sentido proposto pelos estudos brasileiros. Ao desagregarmos os dados por vara temos para cada uma das subpopulações uma distribuição muito parecida dos tempos médios de sentença (gráfico l).

O fato da população negra e parda apresentar mais casos desviantes para furto não é significativo, pois a distribuição do tempo de sentença neste tipo penal para esta população é mais concentrado em torno da média, o que diminui o desvio padrão desta categoria. Estes casos desviantes também estão dentro da distribuição da média de sentença da população branca.

O tipo penal furto apresenta um número de casos baixo para as varas, o que faz com que o erro desta amostra aumente e possa gerar variações. No caso de roubo o dado é mais robusto, pois o número de casos de condenação é bem maior, e, novamente, temos o comportamento no sentido contrário do que seria esperado pelos estudos brasileiros.

Gráfico I - Boxplot pela média de dias de condenação para brancos e pardos para furto e para roubo
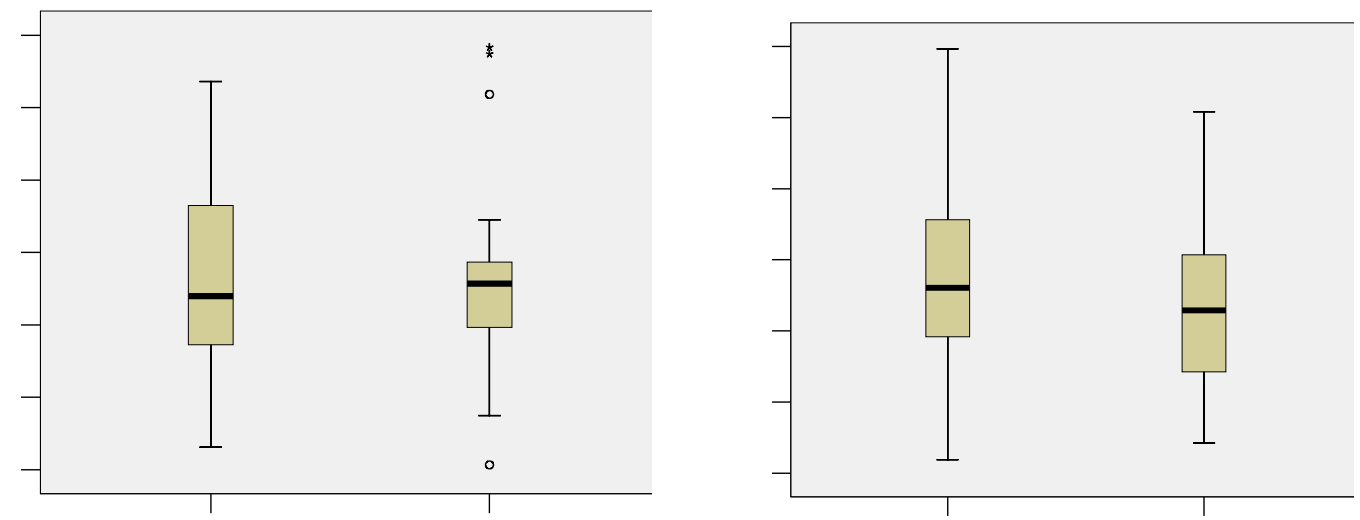
$\mathrm{Na}$ variável região de origem geográfica, que foi dividida em duas categorias para diferenciar os réus nordestinos dos demais, os nordestinos apresentam média de condenação ligeiramente menor quando cometem furto, e no caso de roubo têm a média ligeiramente maior. Mas este grupo apresenta um desvio padrão grande, não permitindo afirmar que haja qualquer padrão de discriminação.

Tabela XXX - Média e desvio padrão do tempo de sentença em meses em função da região de origem do réu.

\begin{tabular}{lcccc} 
& & Furto & \multicolumn{2}{c}{ Roubo } \\
& Não nordeste & Nordeste & Não nordeste & Nordeste \\
\hline Média & 18,72 & 17,97 & 81,75 & 85,81 \\
Desvio Padrão & 11,95 & 12,23 & 119,58 & 133,80 \\
\hline
\end{tabular}

O teste da ANOVA aponta também que a maior parte da variância no tempo de sentença é dada, em ambos os casos, por características individuais e não por uma característica atribuída à variável região de origem do réu. A parcela da variância explicada por esta variável é desprezível frente à variância atribuída a características dos indivíduos.

Tabela XXXI - Teste ANOVA para variação da sentença em meses em função da região de origem do réu.

\begin{tabular}{llccccc}
\hline Tipo Penal & \multicolumn{1}{c}{ Fonte } & $\sum$ dos quadrados & $\begin{array}{c}\text { Gl de } \\
\text { liberdade }\end{array}$ & $\begin{array}{c}\text { Média dos } \\
\text { quadrados }\end{array}$ & Razão F & Significância \\
\hline \multirow{3}{*}{ Furto } & Entre grupos & 75,591 & 1 & 75,591 & 0,52 & 0,47 \\
& Intra grupos & 132900,110 & 922 & 144,143 & & \\
& Total & 132975,701 & 923 & & 0,57 \\
\multirow{2}{*}{ Roubo } & Entre grupos & 4788,717 & 1 & 4788,717 & & 0,32 \\
& Intra grupos & 28251291,024 & 1885 & 14987,422 & & \\
\hline
\end{tabular}

Comparando a pena dos réus com escolaridade até o primeiro grau completo, com a dos réus com escolaridade de segundo grau completo até superior vemos que, no caso de furto, a pena dos réus de maior escolaridade é, em média, maior que a dos réus de baixa escolaridade. No caso de roubo estas penas são 
muito parecidas, com as penas dos réus de maior escolaridade formando um grupo mais homogêneo em torno da média.

Tabela XXXII - Média e desvio padrão do tempo de sentença em meses em função da escolaridade do réu.

\begin{tabular}{lcccc}
\hline & \multicolumn{2}{c}{ Furto } & \multicolumn{2}{c}{ Roubo } \\
& Até $\mathbf{1}^{\circ}$ grau & $\mathbf{2}^{\circ}$ grau ou mais & Até $\mathbf{1}^{\circ}$ grau & $\mathbf{2}^{\circ}$ grau ou mais \\
\hline Média & 17,60 & 21,90 & 80,69 & 79,82 \\
Desvio Padrão & 11,46 & 10,79 & 115,34 & 92,22 \\
\hline
\end{tabular}

O teste da ANOVA aponta também uma diferença significativa entre as escolaridades nos casos de furto, com indivíduos de maior escolaridade recebendo penas maiores. O que pode estar ocorrendo neste caso é que esta variável é uma proxy da variável renda, e estes indivíduos têm condição de pagar melhores advogados, levando a uma maior taxa de absolvição ou substituição de sentenças (como veremos posteriormente), e só os casos mais graves seriam condenados, repercutindo em penas médias mais longas. Para os casos de roubo, nos quais a taxa de condenação é bem mais alta, o comportamento de ambos os grupos é parecido.

Novamente, a maior parte da variância no tempo de sentença é explicada, em ambos os casos, por características individuais e não por uma característica atribuída à variável escolaridade do réu. A parcela da variância explicada por esta variável é muito pequena frente à variância atribuída a características dos indivíduos. 
Tabela XXXIII - Teste ANOVA para variação da sentença em meses em função da escolaridade do réu.

\begin{tabular}{|c|c|c|c|c|c|c|}
\hline Tipo Penal & Fonte & $\sum$ dos quadrados & $\begin{array}{c}\text { GI de } \\
\text { liberdade }\end{array}$ & $\begin{array}{l}\text { Média dos } \\
\text { quadrados }\end{array}$ & Razão F & Significância \\
\hline \multirow{3}{*}{ Furto } & Entre grupos & 1694,259 & 1 & 1694,259 & \multirow{3}{*}{13,10} & \multirow{3}{*}{0,00} \\
\hline & Intra grupos & 93592,300 & 724 & 129,271 & & \\
\hline & Total & 95286,559 & 725 & & & \\
\hline \multirow{3}{*}{ Roubo } & Entre grupos & 154,911 & 1 & 154,911 & \multirow{3}{*}{0,01} & \multirow{3}{*}{0,91} \\
\hline & Intra grupos & 20426605,729 & 1622 & 12593,468 & & \\
\hline & Total & 20426760,640 & 1623 & & & \\
\hline
\end{tabular}

Analisando a ocupação econômica do réu, se economicamente ativa ou não economicamente ativa, a diferença de média de meses de condenação é muito pequena em ambos os tipos penais, com a população economicamente ativa tendo médias um pouco maiores para furto e um pouco menores para roubo, com desvios padrões muito próximos.

Tabela XXXIV - Média e desvio padrão do tempo de sentença em meses em função da ocupação econômica do réu.

\begin{tabular}{lcccc}
\hline & \multicolumn{2}{c}{ Furto } & \multicolumn{2}{c}{ Roubo } \\
& $\begin{array}{c}\text { Economicamente } \\
\text { Ativo }\end{array}$ & $\begin{array}{c}\text { Não economic. } \\
\text { Ativo }\end{array}$ & $\begin{array}{c}\text { Economicamente } \\
\text { Ativo }\end{array}$ & $\begin{array}{c}\text { Não economic. } \\
\text { Ativo }\end{array}$ \\
\hline Média & 18,88 & 18,07 & 80,96 & 82,18 \\
Desvio Padrão & 12,35 & 11,13 & 114,24 & 118,34 \\
\hline
\end{tabular}

Mais uma vez, o teste da ANOVA aponta que a maior parte da variância no tempo de sentença é dada, em ambos os casos, por características individuais e não por uma característica atribuída à variável ocupação econômica do réu. A parcela da variância explicada por esta variável é desprezível frente à variância atribuída a características dos indivíduos. 
Tabela XXXV - Teste ANOVA para variação da sentença em meses em função da ocupação econômica do réu.

\begin{tabular}{llccccc}
\hline Tipo Penal & \multicolumn{1}{c}{ Fonte } & $\sum$ dos quadrados & $\begin{array}{c}\text { Gl de } \\
\text { liberdade }\end{array}$ & $\begin{array}{c}\text { Média dos } \\
\text { quadrados }\end{array}$ & Razão F & Significância \\
\hline \multirow{2}{*}{ Furto } & Entre grupos & 123,58 & 1 & 123,57 & & 0,35 \\
& Intra grupos & 123115,217 & 857 & 143,658 & 0,86 & 0,83 \\
& Total & 123238,793 & 858 & & 0,45 & \\
\multirow{2}{*}{ Roubo } & Entre grupos & 603,433 & 1 & 603,433 & & \\
& Intra grupos & 23618428,573 & 1765 & 13381,546 & & \\
\hline
\end{tabular}

Analisando as regressões dos modelos de tempo de sentença em meses com base nas variáveis discutidas ao longo do capítulo 3, vemos que para o tipo penal furto, o modelo 3 , no qual é introduzido o conjunto de variáveis sócioeconômicas, explica apenas $3,3 \%$ da variação dos meses de condenação. Destas variáveis, são significativas para o modelo o estado civil identificando os casados, para os quais o tempo de sentença aumenta em 3,265 meses em média, e os réus com segundo grau completo ou superior, que tem a pena em média 4,576 meses maior do que os réus com até $1^{\circ}$ grau. Ambas têm comportamento diverso do que propõem os estudos revisados.

Uma suposição que fazemos, mas que não é factível de comprovar com os dados disponíveis, é que como a variável casados está medianamente associada com a variável idade $(V$ de Cramer $=24,6 \%)$, esta variável poderia estar capturando em parte o efeito de uma variável processual que é a reincidência, pois o número de casos de réus reincidentes deve ser maior entre os maiores de 25 anos.

Para a variável dos indivíduos com segundo grau ou mais de escolaridade, a explicação pode estar relacionada com o fato desta variável ser uma proxy da variável renda. Com isto, estes réus podem teoricamente contratar melhores advogados e assim livrar-se da condenação, o que elevaria a média de meses desta 
categoria, pois só os casos mais graves seriam condenados, e estes casos tem em média penas maiores.

No modelo 2 incluímos as variáveis processuais disponíveis no nosso banco de dados e que medem os efeitos dos artigos da legislação que alteram a pena. As variáveis são se o réu foi condenado com base em artigos que agravam a pena base; ou no artigo 14, inciso II, de tentativa, que atenua a pena base; se o réu possuía o atenuante de idade que contempla os menores de 21 anos e maiores de 70 anos; e se responderam ao processo mais de um réu. Com a introdução destas variáveis a capacidade de explicação do modelo melhora sensivelmente, explicando $41,6 \%$ da variação.

Examinando o coeficiente beta ${ }^{3}$ que padroniza as variáveis colocando-as numa mesma escala de valores, vemos que as duas variáveis mais importantes são o réu ter sido denunciado por um dos artigos de furto que agrava a pena e ter tido a pena atenuada pela tentativa. No caso, se a punição está sendo aplicada de acordo com a concepção do direito positivo que organiza o sistema de justiça penal, este é o resultado esperado, pois a variação deve ser explicada pela legislação.

As outras variáveis significantes no modelo 2 são novamente a idade do réu, se menor de 25 anos; a variável casado; a variável escolaridade igual à segundo grau ou mais; e a variável mais de um réu no processo. A explicação para as três primeiras é a mesma do modelo 3, e para a variável mais de um réu, provavelmente ela seja uma proxy de outra variável processual, a agravante do concurso de pessoas, que aumenta o tempo de sentença.

No modelo 1 introduzimos mais cinco variáveis (termos interativos) que isolam o efeito das variáveis processuais do efeito de cor, da região de origem, e

\footnotetext{
${ }^{3} \mathrm{O}$ coeficiente beta é uma medida que padroniza as unidades de medida das diversas variáveis numa unidade de mesmo valor, logo, comparando os seus valores, temos como diferenciar a importância das diversas variáveis para a composição da equação de regressão.
} 
atenuante pela idade da variável idade. A introdução destas variáveis visa testar se os artigos que agravam a pena ou o artigo de tentativa são aplicados gerando distinção entre os réus brancos e os réus pardos e negros, e entre os réus nordestinos e não nordestinos.

Observando os resultados do modelo 1 vemos que não houve alterações significativas em relação ao modelo 2 , isto é, as variáveis processuais continuam a ser as mais importantes para predizer o tempo de sentença, e tanto a cor quanto a região de origem do réu não têm um efeito significativo sobre a aplicação dos artigos agravantes ou atenuantes disponíveis no banco de dados.

Tabela XXXVI - Coeficientes da regressão linear para meses de condenação para furto

\begin{tabular}{|c|c|c|c|c|c|c|c|c|c|}
\hline \multirow[t]{2}{*}{ Variáveis } & \multicolumn{3}{|c|}{ Modelo 1} & \multicolumn{3}{|c|}{ Modelo 2} & \multicolumn{3}{|c|}{ Modelo 3} \\
\hline & B & SE & Beta & B & SE & Beta & B & SE & Beta \\
\hline (Constant) & $17,803^{* *}$ & 1,610 & & $17,047^{* *}$ & 1,363 & & $16,065^{* *}$ & 1,539 & \\
\hline Homens & ,370 & 1,143 &, 010 & ,377 & 1,140 & ,010 & 1,791 & 1,454 &, 047 \\
\hline Brancos & $-1,605$ & 1,432 &,- 070 &,- 403 & 672 &,- 017 &,- 548 & ,860 &,- 024 \\
\hline$<25$ anos & $-2,137^{* *}$ & ,812 &,- 093 & $-1,942^{*}$ & ,803 &,- 085 &,- 644 & ,898 &,- 028 \\
\hline Nordestinos &,- 846 & 1,912 &,- 029 & $-1,111$ & ,886 &,- 037 &,- 392 & 1,132 &,- 013 \\
\hline Casados & $2,257^{*}$ & 1,022 & ,067 & $2,354^{*}$ & 1,019 &, 070 & $3,265^{*}$ & 1,304 & ,097 \\
\hline $2^{\circ}$ grau ou mais & $1,937^{*}$ & ,962 & ,060 & $1,957^{*}$ & ,957 &, 061 & $4,576^{* *}$ & 1,214 & ,142 \\
\hline Não Econom. Ativo &,- 239 & ,709 &,- 010 &,- 277 & ,708 &,- 012 & ,353 & ,904 & 015 \\
\hline Mais de 1 réu & $1,645^{*}$ &, 795 &, 070 & $1,615^{\star}$ & ,793 & ,069 & & & \\
\hline Qualificado & $7,730^{\star *}$ & 1,230 & ,318 & $9,121^{* *}$ & ,829 & ,376 & & & \\
\hline Tentativa & $-9,116^{\star *}$ & 1,070 &,- 400 & $-9,748^{* *}$ & ,672 &,- 427 & & & \\
\hline Aten. por idade &,- 588 & ,919 &,- 022 &,- 562 & ,914 &,- 021 & & & \\
\hline Int. branco tentat. &,- 703 & 1,358 &,- 028 & & & & & & \\
\hline Int. branco qualific. & 2,286 & 1,453 & ,097 & & & & & & \\
\hline Int. nord. tentativa & $-1,404$ & 1,754 &,- 036 & & & & & & \\
\hline Int. nord. qualific. &, 548 & 1,895 & ,016 & & & & & & \\
\hline
\end{tabular}

\begin{tabular}{l|c|c|c}
\hline $\mathbf{R}^{\mathbf{2}}$ & $0,419^{* *}$ & $0,416^{* *}$ & $0,033^{* *}$ \\
$\mathbf{N}$ & 706 & 706 & 706 \\
\hline
\end{tabular}

** Significância >0,01; * Significância >0,05

O tipo penal roubo não permitiu este tipo de análise de regressão linear para estimar o efeito sobre os meses de sentença, posto que a variável meses de 
sentença apresenta uma distribuição concentrada em torno de um único valor e com poucos casos bem distantes. Isto se deve à homogeneidade dos artigos pelos quais estes réus são denunciados pois, conforme foi mostrado na tabela $X X I, 87,2 \%$ das sentenças são de artigos agravantes da pena base, ao contrário do tipo penal furto, que apresenta uma distribuição mais equilibrada entre artigos agravantes e a de denunciados na pena base, com $67,2 \%$ de réus sendo condenados em artigos agravantes. Outro problema é que não temos em nosso banco de dados todas as variáveis processuais para acrescentar ao modelo, o que poderia também contribuir para este problema.

No entanto, os testes de ANOVA apresentados anteriormente mostraram que as variáveis sócio-econômicas que compõem o modelo têm individualmente associações insignificantes com a variável meses de sentença. O resultado esperado para um modelo como este é um comportamento muito parecido com o apresentado nos modelos de furto, ou seja, as variáveis processuais devem ser as mais importantes para predizer a variação da sentença, o que nos leva a conclusões parecidas.

Analisando a variável condenação ou não a partir de um modelo de regressão logística binária, testamos se os modelos ajudam a prever se o réu será condenado ou o processo terá outro desfecho. Os modelos mostraram uma capacidade preditiva muito baixa. O ganho que trazem à explicação é muito pequeno se compararmos com a probabilidade do evento, pois se incluirmos as variáveis o ganho é de no máximo $2 \%$ no melhor dos modelos.

Atentando apenas para os coeficientes das variáveis vemos que, no caso de furto, no modelo 3, a única variável significante a 0,05 é a escolaridade do réu igual a segundo grau ou superior, que diminui a chance dele ser condenado. A 
escolaridade apresenta comportamento diverso dos modelos de meses de sentença, com os réus de maior escolaridade apresentando uma chance de ser condenado de 0,57 vezes a chance de réus de escolaridade até primeiro grau serem condenados. Este é mais um indício da explicação que levantamos no modelo anterior, de que esta variável deve estar funcionando como uma proxy da variável renda. Esta variação deve ser fruto do tipo de defesa que estes réus têm, com melhores advogados que conseguem livrar da condenação os casos de menor gravidade, só sendo condenados os de maior gravidade.

Quando introduzimos as variáveis processuais, no modelo 2, a variável educação continua a ter efeito. No entanto, a variável tipo penal qualificado é significativamente mais importante para a explicação. O fato do réu ser denunciado num inciso que qualifica o furto faz com que a chance dele ser condenado duplique em relação aos que não são denunciados nestes incisos. A educação tem o mesmo efeito do modelo anterior. Ao introduzirmos as variáveis de interação o comportamento destas duas variáveis significantes não se altera.

No caso de roubo, quando só as variáveis do réu são utilizadas no modelo 3 , a variável cor é significante, com réus brancos tendo risco menor de serem condenados, indo no sentido do que seria esperado pelos estudos nacionais. Contudo, quando introduzimos as variáveis processuais o fato do réu ser branco deixa de ser importante, e a variável origem geográfica ganha significância, indo no mesmo sentido do que propõem os estudos brasileiros, com os réus nordestinos apresentando uma taxa de condenação maior do que os réus de outras regiões.

A chance de um réu nordestino ser condenado é de 1,44 vezes a chance de um réu de outra região ser condenado, mas a variável mais importante é a tentativa. A suposição que fazemos é que, uma vez mais, estamos tratando de uma variável 
proxy, que deve estar capturando o efeito do flagrante, o que segundo TOURINHO FILHO $\left(2000^{a}\right.$, p. 268) aumenta a chance de condenação.

Ao introduzirmos, no modelo 1 , as variáveis de interação entre as variáveis processuais e as variáveis sócio-econômicas, não temos melhora na predição, mas o efeito da origem geográfica deixa de ser importante, pois a interação mostra que a única variável significante é a dos réus nordestinos que foram denunciados por tentativa. Com isto, temos que a relação do modelo anterior na verdade é fruto de uma distribuição desigual dos grupos dentro de uma característica processual, o que vai no sentido de nossa proposição de que as variáveis importantes para explicar as variações no processo são as processuais.

A introdução das variáveis processuais não elevou a capacidade de predição, pois estas não estão diretamente ligadas ao processo de condenação. Para que o modelo fosse mais robusto e capaz de predizer melhor o resultado desta etapa do processo, seria necessário levantar variáveis que apontassem a relação de causalidade entre a ação do réu e o fato delituoso, que mostrassem a comprovação do ato delituoso, a apresentação de provas válidas, e outras que permitissem verificar se os requisitos processuais para a condenação foram cumpridos. 
Tabela XXXVII - Coeficientes da regressão logística binária para condenação

\begin{tabular}{|c|c|c|c|c|c|c|c|c|c|c|c|c|}
\hline \multirow[t]{3}{*}{ Variável } & \multicolumn{4}{|c|}{ Modelo 1} & \multicolumn{4}{|c|}{ Modelo 2} & \multicolumn{4}{|c|}{ Modelo 3} \\
\hline & \multicolumn{2}{|c|}{ Furto } & \multicolumn{2}{|c|}{ Roubo } & \multicolumn{2}{|c|}{ Furto } & \multicolumn{2}{|c|}{ Roubo } & \multicolumn{2}{|c|}{ Furto } & \multicolumn{2}{|c|}{ Roubo } \\
\hline & Odd & SE & Odd & Se & Odd & SE & Odd & Se & Odd & SE & Odd & Se \\
\hline Homens & 1,59 & ,42 & & & 1,60 & ,41 & & & 1,64 & ,42 & & \\
\hline Brancos & 0,88 &, 34 & ,83 & ,37 & ,99 & ,19 & ,78 & ,10 & ,99 & ,18 &, $77^{*}$ & ,09 \\
\hline$<25$ anos & 1,04 & ,24 & 1,24 & ,21 & 1,03 & ,23 & 1,24 & ,21 & 1,04 & ,20 & 1,09 & ,15 \\
\hline Nordestinos & ,68 & ,35 & 1,57 & ,93 & ,74 & ,18 & $1,44^{*}$ & ,26 & ,76 & ,18 & 1,35 & ,23 \\
\hline Casados & 1,48 & ,45 & ,79 & ,17 & 1,47 & ,44 &, 77 & ,16 & 1,46 & ,44 &, 77 & , 15 \\
\hline $2^{\circ}$ grau ou mais &, $56^{*}$ & ,13 & 1,13 & ,21 &, $56^{*}$ & ,13 & 1,15 & ,21 &, $57^{*}$ & ,13 & 1,15 & ,21 \\
\hline Não Econ. Ativo & ,88 & ,17 & ,91 & ,12 & ,89 & ,17 & ,91 & ,12 & ,91 & ,18 & ,91 &, 12 \\
\hline Mais de 1 réu & ,73 & ,14 & 1,07 & ,14 & ,72 & ,16 & 1,07 & ,14 & & & & \\
\hline Qualificado & $2,00^{*}$ & ,70 & ,88 & ,32 & $2,02^{* *}$ & ,47 & ,79 & ,19 & & & & \\
\hline Tentativa & ,95 &, 29 & 1,17 & ,32 & 1,14 & ,22 & $1,75^{\star *}$ & ,34 & & & & \\
\hline Aten. por idade & ,95 & ,25 & ,85 & ,13 & ,95 & ,25 & ,84 & ,13 & & & & \\
\hline Int. cor tentativa & 1,30 & ,49 & $2,16^{*}$ & ,85 & & & & & & & & \\
\hline Int. cor qualific. & 1,00 & ,41 & ,83 & ,38 & & & & & & & & \\
\hline Int. ne tentativa & 1,19 &, 57 & 1,21 & ,71 & & & & & & & & \\
\hline Int. ne qualific. & 1,01 &, 53 & ,89 &, 55 & & & & & & & & \\
\hline Significância X² & \multicolumn{2}{|c|}{0,106} & \multicolumn{2}{|c|}{0,020} & \multicolumn{2}{|c|}{0,029} & \multicolumn{2}{|c|}{0,013} & \multicolumn{2}{|c|}{0,102} & \multicolumn{2}{|c|}{0,101} \\
\hline Pseudo $\mathbf{R}^{2}$ & \multicolumn{2}{|c|}{0,028} & \multicolumn{2}{|c|}{0,017} & \multicolumn{2}{|c|}{0,028} & \multicolumn{2}{|c|}{0,014} & \multicolumn{2}{|c|}{0,015} & \multicolumn{2}{|c|}{0,006} \\
\hline Acertos nulo (\%) & \multicolumn{2}{|c|}{81,99} & \multicolumn{2}{|c|}{83,06} & \multicolumn{2}{|c|}{81,99} & \multicolumn{2}{|c|}{83,06} & \multicolumn{2}{|c|}{81,99} & \multicolumn{2}{|c|}{83,06} \\
\hline Previsão (\%) & \multicolumn{2}{|c|}{82,28} & \multicolumn{2}{|c|}{85,02} & \multicolumn{2}{|c|}{82,28} & \multicolumn{2}{|c|}{85,02} & 82 , & & 84 & \\
\hline
\end{tabular}

** Significância $>0,01 ;{ }^{*}$ Significância $>0,05$

Analisando o regime da pena utilizamos igualmente os modelos de equação logística binária, nos quais a variável dependente é o regime da pena mais gravoso. No caso de roubo, os modelos prevêem pouco o resultado em virtude, sobretudo, do predomínio da categoria regime fechado, com $85,49 \%$ dos casos sendo condenados a este regime. No caso de furto, o melhor modelo é bem discreto, não prevendo mais do que $3,47 \%$ de acerto em relação ao modelo nulo.

Analisando as variáveis da equação, quando introduzimos no modelo 3 as variáveis do réu, a única significante foi a menor de 25 anos, com os réus desta categoria tendo 0,40 da chance de não ter substituição de sentença em relação aos 
réus com mais de 25 anos. Novamente, esta variável pode estar capturando o efeito de reincidência em crime doloso, um dos pré-requisitos para a substituição da pena.

Introduzindo as variáveis processuais (modelo 2), o efeito das variáveis do réu não se alteram significativamente, mas outras variáveis processuais passam a ser significantes. Estas variáveis são o número de réus, com processos de mais de um réu diminuindo a chance de condenação, o que vai em sentido contrário ao que foi previsto; e a atenuante por idade, o que reforça a idéia que as variáveis de idade estão capturando efeito da variável reincidência.

No modelo 1, ao introduzirmos as interações vemos que a significância das variáveis se mantém e, das variáveis introduzidas, a interação entre nordestinos e tentativa é significante, aumentando a chance de condenação deste grupo específico quando sentenciado no artigo de tentativa. O que há neste caso é uma distribuição desigual de uma característica processual que interfere neste grupo, pois concentra uma característica processual que agrava o tipo de regime, provavelmente por estar capturando o efeito do flagrante e, com isto, este grupo quando sentenciado a este tipo específico tem uma probabilidade maior de ser condenado a regimes mais gravosos.

No caso de roubo, a previsibilidade do modelo é mais baixa, chegando a $0,43 \%$ de aumento nos acertos em relação ao modelo nulo. Parte do problema é que $85,49 \%$ dos réus são sentenciados ao regime fechado, fazendo com que a taxa de previsão seja muito alta, independente de qualquer característica.

Analisando as variáveis do réu, no modelo 3 , vemos que novamente a mais significante é a idade ser inferior a 25 anos, o que reduz a chance de condenação. Novamente, ela deve ser uma proxy de primariedade, o que reduz o tempo de sentença e, conseqüentemente, a chance do réu ser condenado ao regime mais 
gravoso. A variável escolaridade também é importante, indo no sentido esperado pelo modelo, e deve estar capturando o efeito do tipo de advogado. A variável nova que ganha significância é a cor, com réus brancos tendo uma chance de 0,74 vezes a chance de um réu negro ser condenado, como seria de se esperar pelos estudos brasileiros.

Ao introduzirmos as variáveis processuais, no modelo 2 , as variáveis sociais continuam importantes, porém as variáveis processuais de qualificadora e tentativa têm um peso muito maior. $\mathrm{O}$ fato do réu ser denunciado num artigo que qualifica o crime faz com que a probabilidade dele ser condenado seja 5,26 vezes a probabilidade de um réu que não é denunciado nestes incisos. Já o fato dele ser denunciado em tentativa reduz a chance dele ser condenado ao regime fechado, que passa a ser de 0,33 vezes a chance de um réu que não é sentenciado por tentativa.

No caso de roubo, como há uma taxa de condenação muito grande em relação ao total de processos, e como não há a possibilidade de suspensão como no caso de furto, esta variável acaba funcionando com o efeito que tem sobre o cálculo da pena, com a redução desta e a conseqüente passagem para regimes menos gravosos.

Ao introduzirmos as variáveis de interação vemos que a variável cor deixa de ser significante e o atenuante por idade ganha significância, isto é, na amostra de réus negros há alguma característica processual que altera a distribuição de casos e impacta o regime, e não o efeito da discriminação de cor. A variável atenuante por idade tem o sentido esperado, reduzindo a chance de condenação a regime mais gravoso. 
Tabela XXXVIII - Coeficientes da regressão logística binária para regime da pena

\begin{tabular}{|c|c|c|c|c|c|c|c|c|c|c|c|c|}
\hline \multirow[t]{3}{*}{ Variável } & \multicolumn{4}{|c|}{ Modelo 1} & \multicolumn{4}{|c|}{ Modelo 2} & \multicolumn{4}{|c|}{ Modelo 3} \\
\hline & \multicolumn{2}{|c|}{ Furto } & \multicolumn{2}{|c|}{ Roubo } & \multicolumn{2}{|c|}{ Furto } & \multicolumn{2}{|c|}{ Roubo } & \multicolumn{2}{|c|}{ Furto } & \multicolumn{2}{|c|}{ Roubo } \\
\hline & Odd & SE & Odd & Se & Odd & SE & Odd & Se & Odd & SE & Odd & Se \\
\hline Homens & 0,76 & ,35 & & & 0,76 & ,35 & & & 0,72 & ,37 & & \\
\hline Brancos & 0,98 & ,35 & 0,60 &, 57 & 0,88 & ,18 & $0,71^{*}$ & ,22 & 0,92 & ,17 & $0,74^{*}$ & ,20 \\
\hline$<25$ anos & $0,57^{* *}$ & ,33 & $0,53^{* *}$ & ,41 & $0,54^{* *}$ & ,34 & $0,53^{* *}$ &, 40 & $0,40^{* *}$ & ,41 & $0,58^{* *}$ &, 30 \\
\hline Nordestinos & 0,47 & ,98 & 1,69 & ,26 & 0,77 & ,28 & 0,85 & ,23 & 0,78 &, 27 & 0,86 & ,21 \\
\hline Casados & 1,20 & ,20 & 0,95 & ,29 & 1,18 & ,20 & 0,93 & ,30 & 1,23 & , 19 & 1,05 & ,25 \\
\hline $2^{\circ}$ grau ou mais & 0,93 & ,25 & $0,63^{*}$ & ,32 & 0,95 & ,24 & $0,63^{*}$ & ,32 & 0,88 & ,26 & $0,68^{*}$ & ,27 \\
\hline Não Econ. Ativo & 1,00 & ,17 & 1,10 & ,15 & 1,02 &, 17 & 1,10 & ,15 & 0,96 & ,17 & 0,99 & ,15 \\
\hline Mais de 1 réu & $0,65^{*}$ & ,30 & 0,93 & ,19 & $0,64^{*}$ & ,30 & 0,93 & ,18 & & & & \\
\hline Qualificado & 1,35 &, 22 & $5,26^{* *}$ &, 06 & 1,22 &, 16 & $5,26^{* *}$ & ,04 & & & & \\
\hline Tentativa & 0,98 &, 26 & $0,35^{* *}$ & ,72 & 1,16 &, 14 & $0,33^{* *}$ & ,48 & & & & \\
\hline Aten. por idade & $0,46^{* *}$ &, 50 & $0,67^{*}$ & ,27 & $0,48^{* *}$ & ,48 & 0,67 & ,27 & & & & \\
\hline Int. cor tentativa & 0,99 & ,33 & 1,14 & ,28 & & & & & & & & \\
\hline Int. cor qualific. & 0,85 & ,41 & 1,19 & ,31 & & & & & & & & \\
\hline Int. ne tentativa & $2,70^{*}$ & , 16 & 0,51 & ,77 & & & & & & & & \\
\hline Int. ne qualific. & 0,93 & ,49 & 0,57 & ,80 & & & & & & & & \\
\hline Significância $X^{2}$ & \multicolumn{2}{|c|}{0,000} & \multicolumn{2}{|c|}{0,000} & \multicolumn{2}{|c|}{0,000} & \multicolumn{2}{|c|}{0,000} & \multicolumn{2}{|c|}{0,000} & \multicolumn{2}{|c|}{0,003} \\
\hline Pseudo $\mathbf{R}^{2}$ & \multicolumn{2}{|c|}{0,067} & \multicolumn{2}{|c|}{0,123} & \multicolumn{2}{|c|}{0,061} & \multicolumn{2}{|c|}{0,119} & \multicolumn{2}{|c|}{0,043} & \multicolumn{2}{|c|}{0,015} \\
\hline Acertos nulo (\%) & \multicolumn{2}{|c|}{59,91} & \multicolumn{2}{|c|}{85,49} & \multicolumn{2}{|c|}{59,91} & \multicolumn{2}{|c|}{85,49} & \multicolumn{2}{|c|}{59,91} & \multicolumn{2}{|c|}{85,49} \\
\hline Previsão (\%) & \multicolumn{2}{|c|}{63,10} & \multicolumn{2}{|c|}{85,94} & \multicolumn{2}{|c|}{63,38} & \multicolumn{2}{|c|}{85,94} & 61,8 & & 85 , & \\
\hline
\end{tabular}

** Significância >0,01; * Significância >0,05

Mais uma vez, nossa explicação vai no sentido de que o que está gerando alterações nas probabilidades são as variáveis processuais e não as características sociais do réu. Os efeitos das características sociais não são estáveis nos modelos para tipos penais diferentes e, mesmo dentro do mesmo tipo penal, quando fazemos a interação das variáveis sociais com as processuais verifica-se uma distorção em função de uma distribuição desigual dos grupos dentro das características processuais.

Partindo para o segundo problema que abordamos nesta dissertação, vamos fazer um estudo exploratório dos recursos para procurar quais são as 
motivações extra legais ou legais que têm um peso significativo e, por conseqüência, levam os atores a recorrer da sentença de primeira instância.

O primeiro ator que abordaremos é o Ministério Público. As sentenças recorridas por este ator são 9,93\% dos casos de roubo e apenas 3,45 \% dos casos de furto. Em ambos os tipos penais, ao introduzirmos as variáveis do réu (modelo 2), as regressões não são significantes e a capacidade preditiva é nula, não apresentando nenhuma variável significante. Introduzindo as variáveis processuais (modelo 1) as regressões continuam com baixa capacidade de predição e só a de roubo é significante.

Analisando as variáveis do modelo 1 , no caso de furto a única variável significante é o regime da pena para o qual o réu foi condenado, mas em sentido contrário do que seria esperado. O Ministério Público, no caso de furto, recorre mais de condenações a regimes de penas impostos ao réu do que das penas substitutivas. Isto pode ou ser um problema da amostra, uma vez que neste tipo penal o recurso do MP é raro, ou é um indicador que o MP aceita a substituição de penas como punição a estes crimes de menor gravidade.

Quanto ao tipo penal roubo, o modelo é significante, porém, a capacidade preditiva é muito baixa. Isto ocorre porque este é um evento raro, não chegando a $10 \%$ das condenações. Analisando as variáveis, vemos que é significante a concordância entre a denúncia e a sentença por tentativa, o que reduz a probabilidade de recurso. Neste caso, se ambas as decisões são concordantes a chance do recurso é de 0,54 a chance dos casos nos quais não há concordância. $A$ variável educação segundo grau ou mais também é significante, pois este grupo tem, proporcionalmente, menores taxas de condenação e sentenças em regimes mais brandos. No entanto, a variável mais importante é o regime da pena. Quando o 
réu é condenado ao regime fechado, a chance do Ministério Público recorrer é 0,26 vezes a chance de recurso quando ele é condenado ao regime aberto ou semiaberto.

Tabela XXXIX - Coeficientes da regressão logística binária para recurso do Ministério Público nos casos de condenação.

\begin{tabular}{|c|c|c|c|c|c|c|c|c|}
\hline \multirow[t]{3}{*}{ Variável } & \multicolumn{4}{|c|}{ Modelo 1} & \multicolumn{4}{|c|}{ Modelo 2} \\
\hline & \multicolumn{2}{|c|}{ Furto } & \multicolumn{2}{|c|}{ Roubo } & \multicolumn{2}{|c|}{ Furto } & \multicolumn{2}{|c|}{ Roubo } \\
\hline & Odd & SE & Odd & Se & Odd & SE & Odd & $\mathrm{Se}$ \\
\hline Homens & ,56 & ,37 & & & ,76 & ,43 & & \\
\hline Brancos & 1,20 &, 57 & 1,01 & ,18 & 1,05 & ,40 & 1,00 & ,16 \\
\hline$<25$ anos & 2,74 & 1,44 & 1,20 & ,25 & 1,43 &, 57 & 1,21 & ,22 \\
\hline Nordestinos & 1,41 & ,85 & 1,25 & ,28 & ,96 & ,49 & 1,07 & ,21 \\
\hline Casados & ,34 & ,36 & 0,96 & ,30 & ,26 & ,27 & ,83 & ,24 \\
\hline $2^{\circ}$ grau ou mais & ,70 &, 55 & $1,69^{*}$ & ,38 & ,33 & ,25 & 1,42 & ,28 \\
\hline Não Econ. Ativo & ,72 & ,37 & 0,92 & ,17 & 1,29 & ,49 & ,92 & ,15 \\
\hline Concord. Tent. &, 39 & ,20 & $0,54^{*}$ & ,13 & & & & \\
\hline Concord. Qualif. & ,40 & ,22 & 0,82 & ,34 & & & & \\
\hline Meses pena & ,99 & ,02 & 1,00 &, 00 & & & & \\
\hline Regime sentença & $3,45^{*}$ & ,15 & $0,26^{* *}$ &, 53 & & & & \\
\hline Significância $X^{2}$ & \multicolumn{2}{|c|}{0,108} & \multicolumn{2}{|c|}{0,000} & \multicolumn{2}{|c|}{0,356} & \multicolumn{2}{|c|}{0,561} \\
\hline Pseudo $\mathbf{R}^{2}$ & \multicolumn{2}{|c|}{0,094} & \multicolumn{2}{|c|}{0,066} & \multicolumn{2}{|c|}{0,030} & \multicolumn{2}{|c|}{0,004} \\
\hline Acertos nulo (\%) & \multicolumn{2}{|c|}{96,55} & \multicolumn{2}{|c|}{90,07} & \multicolumn{2}{|c|}{96,55} & \multicolumn{2}{|c|}{90,07} \\
\hline Previsão (\%) & \multicolumn{2}{|c|}{96,58} & \multicolumn{2}{|c|}{90,39} & \multicolumn{2}{|c|}{96,58} & \multicolumn{2}{|c|}{90,00} \\
\hline
\end{tabular}

** Significância >0,01; * Significância >0,05

Novamente, vemos que este é um ator que está agindo processualmente e mesmo a variável social é também proxy de uma variável que não consta do banco de dados, que é o tipo de advogado. Os réus de maior escolaridade, que estão associados às maiores rendas, têm condições de contratar melhores advogados, o que faz com que a proporção dos que são condenados a penas no regime fechado seja menor nesta categoria, como mostraram os modelos anteriores. Por esta razão, as decisões acerca deste grupo são mais recorridas pelo MP.

O segundo ator é o advogado do réu. As sentenças recorridas representam $50,15 \%$ dos casos de condenação de furto e $82,38 \%$ dos casos de condenação de 
roubo. Em ambos os tipos penais, ao introduzirmos as variáveis do réu (modelo 2), o modelo não é significante e a capacidade preditiva é nula, apresentando, no caso de furto, apenas a variável não economicamente ativo como significativa. A chance dos indivíduos deste grupo recorrerem é 1,52 vezes a chance dos não economicamente ativos recorrerem. Introduzindo as variáveis processuais (modelo 1) ambas as regressões tornam-se significantes. A regressão de furto continua com baixa capacidade de predição, mas no caso de roubo há uma melhora sensível, com a capacidade de predição passando de 50,15\% para $65,25 \%$ de acerto.

Analisando as variáveis do modelo 2 no caso de furto, as variáveis significantes são de novo os réus não economicamente ativos, que tem uma chance de recorrer igual à 1,62 vezes a chance dos não economicamente ativos recorrerem. Mas as variáveis mais importantes para o modelo são as processuais meses e regime da pena, indo no sentido esperado.

No caso de meses de pena, cada mês a mais de pena eleva a chance de recorrer em 1,04 vezes. Já no caso do regime da pena, se o réu foi condenado a uma pena que não foi substituída a chance dele recorrer é 2,04 vezes a chance dele recorrer caso o juiz tenha aplicado a substituição.

Quanto ao tipo penal roubo, o modelo é significante e a capacidade preditiva, como dissemos, é razoável. Analisando as variáveis, vemos que é significante o réu ser não economicamente ativo, aumentando a chance de recurso; a concordância entre a denúncia por tentativa e a sentença por tentativa, ao contrário do comportamento do Ministério Público, aumenta a chance de recurso. Ela é igual a 1,64 vezes a chance de recurso quando a denúncia e a sentença são discordantes quanto à tentativa; mas a principal variável é o regime da pena, que 
quando definido como fechado faz com que a chance de recurso seja 3,54 vezes a chance dos condenados aos outros regimes recorrerem.

Tabela XXXX - Coeficientes da regressão logística binária para recurso do réu nos casos de condenação.

\begin{tabular}{|c|c|c|c|c|c|c|c|c|}
\hline \multirow[t]{3}{*}{ Variável } & \multicolumn{4}{|c|}{ Modelo 1} & \multicolumn{4}{|c|}{ Modelo 2} \\
\hline & \multicolumn{2}{|c|}{ Furto } & \multicolumn{2}{|c|}{ Roubo } & \multicolumn{2}{|c|}{ Furto } & \multicolumn{2}{|c|}{ Roubo } \\
\hline & Odd & SE & Odd & Se & Odd & SE & Odd & Se \\
\hline Homens & ,99 & ,33 & & & 1,32 & 41 & & \\
\hline Brancos & 1,12 & ,22 & ,90 & ,10 & 1,01 & ,19 & ,84 & 08 \\
\hline$<25$ anos & 1,41 & ,30 & ,98 & ,12 & 1,23 & ,24 & ,94 & 10 \\
\hline Nordestinos & $1,66^{*}$ & ,42 & 1,10 & ,15 & 1,47 & ,33 & 1,20 & 14 \\
\hline Casados & 1,30 & ,37 & ,76 & 14 & 1,45 & ,38 & ,83 & ,13 \\
\hline $2^{\circ}$ grau ou mais & 1,40 & ,37 & 1,11 &, 17 & 1,27 & ,30 & 1,06 & , 14 \\
\hline Não Econ. Ativo & $1,67^{*}$ & ,34 & $1,27^{*}$ & ,14 & $1,52^{*}$ & ,28 & 1,12 & ,11 \\
\hline Concord. Tent. & 67 & 18 & $1,69^{* *}$ & ,31 & & & & \\
\hline Concord. Qualif. & 1,09 & 37 & 1,52 & ,44 & & & & \\
\hline Meses pena & $1,04^{* *}$ &, 01 & 1,00 &, 00 & & & & \\
\hline Regime sentença & $2,04^{* *}$ & 10 & $3,59^{* *}$ &, 59 & & & & \\
\hline Significância $X^{2}$ & \multicolumn{2}{|c|}{0,000} & \multicolumn{2}{|c|}{0,000} & \multicolumn{2}{|c|}{0,140} & \multicolumn{2}{|c|}{0,166} \\
\hline Pseudo $\mathbf{R}^{2}$ & \multicolumn{2}{|c|}{0,081} & \multicolumn{2}{|c|}{0,055} & \multicolumn{2}{|c|}{0,014} & \multicolumn{2}{|c|}{0,004} \\
\hline Acertos nulo (\%) & \multicolumn{2}{|c|}{82,38} & \multicolumn{2}{|c|}{50,15} & \multicolumn{2}{|c|}{82,38} & \multicolumn{2}{|c|}{50,15} \\
\hline Previsão (\%) & \multicolumn{2}{|c|}{79,80} & \multicolumn{2}{|c|}{65,25} & \multicolumn{2}{|c|}{82,76} & \multicolumn{2}{|c|}{53,19} \\
\hline
\end{tabular}

** Significância >0,01; * Significância >0,05

Mais uma vez, temos uma evidência de que o sistema está trabalhando tecnicamente, pois são pontos controversos dentro do processo que têm maior importância na explicação do recurso, e não as variáveis ligadas a características do réu.

Por fim, abordando o terceiro problema, faremos uma análise dos casos disponíveis sem generalizações ao universo de juízes da comarca de São Paulo. Observando a proporção de condenação, vemos que no caso de furto só há uma diferença significativa entre o juiz que ocupava a segunda posição mais dura em relação ao direito penal e o segundo juiz mais brando. Desconsiderando a significância e olhando para o sentido das relações, vemos que estes são os juízes 
mais extremados em relação às médias de sentença, pois os outros três juízes se distribuem com médias intermediárias a estes casos. Se agruparmos as observações, verificamos que se formam dois grupos, com os dois juízes mais brandos próximos entre si e os mais duros também próximos entre si.

No caso de roubo, as distâncias diminuem e não há nenhum caso significativo, mas a direção das relações continua coerente com o posicionamento frente ao direito penal, mas com uma inversão. O juiz mais central passa do lado dos juízes mais rígidos para o lado dos juízes brandos. Parece, no caso da condenação, existir uma polarização entre os juízes 1 e 2 e os juízes 4 e 5, com o juiz 3 oscilando entre os dois grupos. Como esta numeração dos juízes é atribuída de acordo com a sua localização no contínuo de rigidez e brandura, vemos que o posicionamento está coerente, embora não seja uma análise conclusiva, e parece indicar uma influência desta posição frente ao direito penal na taxa de condenação.

Tabela XXXXI - Teste de BONFERRONI para diferença de médias entre juízes para condenação

\begin{tabular}{|c|c|c|c|c|c|c|c|c|c|c|}
\hline \multirow[b]{2}{*}{ Juiz } & \multicolumn{5}{|c|}{ Diferença média para furto } & \multicolumn{5}{|c|}{ Diferença média para roubo } \\
\hline & 1 & 2 & 3 & 4 & 5 & 1 & 2 & 3 & 4 & 5 \\
\hline 1 & - & $\begin{array}{c}-, 081 \\
(0,083)\end{array}$ & $\begin{array}{c}-0,21 \\
(0,076)\end{array}$ & $\begin{array}{c}0,181 \\
(0,083)\end{array}$ & $\begin{array}{c}0,099 \\
(0,092)\end{array}$ & - & $\begin{array}{l}-0,008 \\
(0,065)\end{array}$ & $\begin{array}{c}0,108 \\
(0,063)\end{array}$ & $\begin{array}{c}0,081 \\
(0,064)\end{array}$ & $\begin{array}{c}0,028 \\
(0,062)\end{array}$ \\
\hline 2 & $\begin{array}{c}0,081 \\
(0,083)\end{array}$ & - & $\begin{array}{c}0,060 \\
(0,080)\end{array}$ & $\begin{array}{l}0,262^{*} \\
(0,086)\end{array}$ & $\begin{array}{c}0,181 \\
(0,096)\end{array}$ & $\begin{array}{c}0,008 \\
(0,065)\end{array}$ & - & $\begin{array}{c}0,116 \\
(0,066)\end{array}$ & $\begin{array}{c}0,090 \\
(0,067)\end{array}$ & $\begin{array}{c}0,036 \\
(0,065)\end{array}$ \\
\hline 3 & $\begin{array}{c}0,021 \\
(0,083)\end{array}$ & $\begin{array}{l}-0,060 \\
(0,080)\end{array}$ & - & $\begin{array}{c}0,202 \\
(0,080)\end{array}$ & $\begin{array}{c}0,121 \\
(0,090)\end{array}$ & $\begin{array}{l}-0,108 \\
(0,063)\end{array}$ & $\begin{array}{l}-0,116 \\
(0,066)\end{array}$ & - & $\begin{array}{l}-0,026 \\
(0,065)\end{array}$ & $\begin{array}{r}-0,080 \\
(0,063)\end{array}$ \\
\hline 4 & $\begin{array}{l}-0,181 \\
(0,083)\end{array}$ & $\begin{array}{l}-0,262^{*} \\
(0,086)\end{array}$ & $\begin{array}{l}-0,202 \\
(0,080)\end{array}$ & - & $\begin{array}{l}-0,081 \\
(0,096)\end{array}$ & $\begin{array}{l}-0,081 \\
(0,064)\end{array}$ & $\begin{array}{l}-0,090 \\
(0,067)\end{array}$ & $\begin{array}{c}0,026 \\
(0,065)\end{array}$ & - & $\begin{array}{l}-0,054 \\
(0,064)\end{array}$ \\
\hline 5 & $\begin{array}{l}-0,099 \\
(0,092)\end{array}$ & $\begin{array}{l}-0,181 \\
(0,096)\end{array}$ & $\begin{array}{l}-0,121 \\
(0,090)\end{array}$ & $\begin{array}{c}0,081 \\
(0,096)\end{array}$ & - & $\begin{array}{l}-0,028 \\
(0,062)\end{array}$ & $\begin{array}{l}-0,036 \\
(0,065)\end{array}$ & $\begin{array}{c}0,080 \\
(0,063)\end{array}$ & $\begin{array}{c}0,054 \\
(0,064)\end{array}$ & - \\
\hline
\end{tabular}

Analisando o regime da pena vemos no caso de furto que não há diferenças significativas. Todos os juízes estão muito próximos, à exceção do juiz 5 que se distancia dos demais tendo uma posição mais branda. Esta distância, contudo, pode 
ser uma distorção da amostra, pois o juiz 4 que é consistente nas demais posições numa posição mais branda, neste tipo penal, atinge uma posição mais dura junto com o juiz número 3. Considerando que a amostra de furto, quando desagregada, é pequena, e como a taxa de substituição é alta em todas as sentenças, esta escala pode estar distorcida.

Ao analisarmos o roubo, que é um dado mais robusto, vemos que o juiz 4 tem a posição branda mais extremada nos regimes de pena, e os casos para os quais a diferença é significativa é novamente para os juízes 1 e 2 . O juiz 3 e o 5 ocupam uma posição central formando um grupo intermediário entre os juízes 1 e 2 mais rígidos, e o 4, mais brando.

\begin{tabular}{|c|c|c|c|c|c|c|c|c|c|c|}
\hline \multirow[b]{2}{*}{ Juiz } & \multicolumn{5}{|c|}{ Diferença média para furto } & \multicolumn{5}{|c|}{ Diferença média para roubo } \\
\hline & 1 & 2 & 3 & 4 & 5 & 1 & 2 & 3 & 4 & 5 \\
\hline 1 & - & $\begin{array}{l}-0,044 \\
(0,106)\end{array}$ & $\begin{array}{l}-0,061 \\
(0,099)\end{array}$ & $\begin{array}{l}-0,060 \\
(0,111)\end{array}$ & $\begin{array}{c}0,113 \\
(0,124)\end{array}$ & - & $\begin{array}{c}0,009 \\
(0,064)\end{array}$ & $\begin{array}{c}0,113 \\
(0,067)\end{array}$ & $\begin{array}{l}0,298^{*} \\
(0,067)\end{array}$ & $\begin{array}{c}0,133 \\
(0,066)\end{array}$ \\
\hline 2 & $\begin{array}{c}0,044 \\
(0,106)\end{array}$ & - & $\begin{array}{l}-0,017 \\
(0,102)\end{array}$ & $\begin{array}{l}-0,016 \\
(0,113)\end{array}$ & $\begin{array}{c}0,157 \\
(0,126)\end{array}$ & $\begin{array}{l}-0,009 \\
(0,064)\end{array}$ & - & $\begin{array}{c}0,104 \\
(0,069)\end{array}$ & $\begin{array}{l}0,290^{*} \\
(0,069)\end{array}$ & $\begin{array}{c}0,124 \\
(0,067)\end{array}$ \\
\hline 3 & $\begin{array}{c}0,061 \\
(0,099)\end{array}$ & $\begin{array}{c}0,017 \\
(0,102)\end{array}$ & - & $\begin{array}{c}0,001 \\
(0,106)\end{array}$ & $\begin{array}{c}0,175 \\
(0,120)\end{array}$ & $\begin{array}{l}-0,113 \\
(0,067)\end{array}$ & $\begin{array}{l}-0,104 \\
(0,069)\end{array}$ & - & $\begin{array}{c}0,185 \\
(0,071)\end{array}$ & $\begin{array}{c}0,020 \\
(0,070)\end{array}$ \\
\hline 4 & $\begin{array}{c}0,060 \\
(0,111)\end{array}$ & $\begin{array}{c}0,016 \\
(0,113)\end{array}$ & $\begin{array}{l}-0,001 \\
(0,106)\end{array}$ & - & $\begin{array}{c}0,173 \\
(0,130)\end{array}$ & $\begin{array}{l}-0,298^{*} \\
(0,067)\end{array}$ & $\begin{array}{l}-0,290^{*} \\
(0,069)\end{array}$ & $\begin{array}{l}-0,185 \\
(0,071)\end{array}$ & - & $\begin{array}{l}-0,165 \\
(0,070)\end{array}$ \\
\hline 5 & $\begin{array}{l}-0,113 \\
(0,124)\end{array}$ & $\begin{array}{l}-0,157 \\
(0,126)\end{array}$ & $\begin{array}{l}-0,175 \\
(0,120)\end{array}$ & $\begin{array}{l}-0,173 \\
(0,130)\end{array}$ & - & $\begin{array}{l}-0,133 \\
(0,066)\end{array}$ & $\begin{array}{l}-0,124 \\
(0,067)\end{array}$ & $\begin{array}{l}-0,020 \\
(0,070)\end{array}$ & $\begin{array}{c}0,165 \\
(0,070)\end{array}$ & - \\
\hline
\end{tabular}

Ao analisarmos a taxa de recurso enfocaremos somente os casos de roubo, visto o número de casos de recurso de furto ser muito baixo, mesmo para os réus. A taxa de recurso não está associada completamente à de regimes de pena mais duros, como poderíamos supor a partir dos resultados do modelo de recurso.

Examinando a taxa de recurso do Ministério Público, observamos que os juízes que têm a maior diferença de médias, e a única significante, são os casos 4 e 
5, que apresentam posições de regime mais próximas. De maneira ainda mais intensa, o caso 4, o mais brando dos juízes, é também o que tem a menor média de recurso do Ministério Público. Os juízes com posição intermediária quanto ao regime são os que apresentam maior média de recurso, enquanto os juízes mais rígidos têm média intermediária.

No caso do réu, o juiz que tem menor taxa de recurso é o juiz 4 , com uma média significativamente menor em relação a todos os demais. 0 juiz 5 ocupa uma posição intermediária, porém mais próxima aos juízes 1, 2 e 3, que formam um bloco de maiores médias de recurso.

Tabela XXXXIII- Teste de BONFERRONI para diferença de médias entre juízes para recursos de roubo

\begin{tabular}{|c|c|c|c|c|c|c|c|c|c|c|}
\hline \multirow[b]{2}{*}{ Juiz } & \multicolumn{5}{|c|}{ Diferença média para recurso do MP } & \multicolumn{5}{|c|}{ Diferença média para recurso do réu } \\
\hline & 1 & 2 & 3 & 4 & 5 & 1 & 2 & 3 & 4 & 5 \\
\hline 1 & - & $\begin{array}{l}-0,040 \\
(0,050)\end{array}$ & $\begin{array}{l}-0,084 \\
(0,048)\end{array}$ & $\begin{array}{c}0,053 \\
(0,050)\end{array}$ & $\begin{array}{l}-0,121 \\
(0,048)\end{array}$ & - & $\begin{array}{l}-0,016 \\
(0,078)\end{array}$ & $\begin{array}{l}-0,007 \\
(0,080)\end{array}$ & $\begin{array}{l}0,431^{*} \\
(0,082)\end{array}$ & $\begin{array}{c}0,112 \\
(0,080)\end{array}$ \\
\hline 2 & $\begin{array}{c}0,40 \\
(0,050)\end{array}$ & - & $\begin{array}{l}-0,044 \\
(0,050)\end{array}$ & $\begin{array}{c}0,092 \\
(0,052)\end{array}$ & $\begin{array}{l}-0,082 \\
(0,050)\end{array}$ & $\begin{array}{c}0,016 \\
(0,078)\end{array}$ & - & $\begin{array}{c}0,010 \\
(0,082)\end{array}$ & $\begin{array}{l}0,448^{*} \\
(0,084)\end{array}$ & $\begin{array}{r}0,128 \\
(0,082)\end{array}$ \\
\hline 3 & $\begin{array}{c}0,084 \\
(0,048)\end{array}$ & $\begin{array}{c}0,044 \\
(0,050)\end{array}$ & - & $\begin{array}{c}0,137 \\
(0,050)\end{array}$ & $\begin{array}{l}-0,037 \\
(0,048)\end{array}$ & $\begin{array}{c}0,007 \\
(0,080)\end{array}$ & $\begin{array}{l}-0,010 \\
(0,082)\end{array}$ & - & $\begin{array}{l}0,433^{*} \\
(0,086)\end{array}$ & $\begin{array}{c}0,119 \\
(0,084)\end{array}$ \\
\hline 4 & $\begin{array}{l}-0,053 \\
(0,050)\end{array}$ & $\begin{array}{l}-0,092 \\
(0,052)\end{array}$ & $\begin{array}{l}-0,137 \\
(0,050)\end{array}$ & - & $\begin{array}{l}-0,174^{*} \\
(0,050)\end{array}$ & $\begin{array}{l}-0,431^{*} \\
(0,082)\end{array}$ & $\begin{array}{c}-0,448^{\star} \\
(0,084)\end{array}$ & $\begin{array}{c}-0,433^{*} \\
(0,086)\end{array}$ & - & $\begin{array}{l}-0,319^{*} \\
(0,086)\end{array}$ \\
\hline 5 & $\begin{array}{c}0,121 \\
(0,048)\end{array}$ & $\begin{array}{c}0,082 \\
(0,050)\end{array}$ & $\begin{array}{c}0,037 \\
(0,048)\end{array}$ & $\begin{array}{l}0,174^{*} \\
(0,050)\end{array}$ & - & $\begin{array}{l}-0,112 \\
(0,080)\end{array}$ & $\begin{array}{l}-0,128 \\
(0,082)\end{array}$ & $\begin{array}{l}-0,119 \\
(0,084)\end{array}$ & $\begin{array}{l}0,319^{*} \\
(0,086)\end{array}$ & - \\
\hline
\end{tabular}

O resultado do Ministério Público não apresenta um padrão, o que pode ser uma distorção da amostra, visto este evento ser raro. O resultado do réu mostra que o recurso acompanha o padrão ideológico dos grupos de juízes, mas pode também ser reflexo da variação nas proporções de regime mais gravoso, ou de proporção de condenação maior. 
Para o recurso do réu parece que há uma ligação com este posicionamento ideológico do direito penal, uma vez que os juízes mais brandos têm média de recurso proporcionalmente menor.

O conjunto dos dados parece indicar que o posicionamento frente ao direito penal tem uma influência nas decisões dos juízes, sendo um indício que futuramente pode ser explorado por outros estudos, embora estatisticamente não possamos comprovar sua significância e nem o seu peso para a explicação, em razão dos problemas antes descritos. 


\section{6 - Conclusão}

Após a análise dos dados apresentada no capítulo anterior, concluiremos esta dissertação retomando as hipóteses levantadas pelos estudos brasileiros de sentença expostas no primeiro capítulo.

A) Os réus negros são condenados em maior proporção do que os réus das outras regiões;

A primeira hipótese mostrou-se falsa, uma vez que tanto para furto como para roubo a relação entre a condenação de réus negros e brancos foi insignificante.

B) Os réus negros são condenados a penas mais duras que os réus de outras regiões;

Esta segunda hipótese foi igualmente insignificante para furto quando rodamos o modelo que explica variações no tempo de sentença. Para roubo não foi possível rodar o modelo linear para tempo de sentença, mas pela análise das ANOVAS e pela similaridade dos resultados encontrados para ambas as variáveis, temos fortes indícios para supor que esta relação seja igualmente insignificante.

Quanto ao regime da pena, que poderia manifestar outra forma de condenação mais dura, os resultados encontrados nos modelos de regressão não são significantes para indicar uma influência desta variável sobre o regime da pena. Num primeiro momento, no caso de roubo, esta variável se mostrou significante, mas ao introduzirmos as interações desta variável com as variáveis processuais vimos que a variável se torna insignificante. $\mathrm{Na}$ amostra, os réus brancos e negros têm distribuição desigual dos artigos pelos quais são sentenciados, e esta característica, quando incluída no modelo, tira o efeito da significância.

C) Os réus nordestinos são condenados em maior proporção do que os réus das outras regiões;

Esta proposição também se mostrou falsa. No caso de furto, nenhum dos modelos comprovou que esta variável é significante. No caso de roubo, ao 
introduzirmos as variáveis processuais o resultado foi no sentido desta proposição, mas ao introduzirmos a interação das variáveis processuais com as de características do réu esta significância desaparece, isto é, este grupo possui alguma característica processual desigual em relação a outro grupo aumentando a chance de condenação, mas não é o fato de ser nordestino que motiva esta relação. D) Os réus nordestinos são condenados a penas mais duras que os réus de outras regiões;

A proposição é igualmente insignificante para furto quando rodamos o modelo que explica variações no tempo de sentença. Para roubo não foi possível rodar o modelo linear para tempo de sentença, mas pela análise das ANOVAS e pela similaridade dos resultados encontrados para ambas as variáveis, temos fortes indícios para supor que esta relação seja igualmente insignificante.

Quanto ao regime da pena, que poderia manifestar outra forma de condenação mais dura, os resultados encontrados nos modelos de regressão não são significantes para indicar uma influência desta variável sobre o regime da pena. Esta variável só é significante quando interage com a variável processual tentativa, o que faz com que os nordestinos que são sentenciados por tentativa tenham penas a regimes mais rigorosos, mas isto provavelmente decorre muito mais da influência desta variável processual, que tem um padrão consistente de significância, do que da variável origem geográfica, que é significante em um modelo isolado.

E) além da cor, o gênero seria importante para predizer o resultado, mulheres negras tenderiam a ser condenadas em maior proporção que qualquer outro grupo de gênero e cor;

No caso de furto não há significância na relação entre sexo e condenação. Já para roubo esta categoria de réu praticamente inexiste, não chegando à $3,5 \%$ da amostra, o que torna inviável qualquer análise deste grupo, uma vez que está sujeito a uma variação muito maior pelo tamanho reduzido. 
F) Os réus de baixo status econômico são condenados em maior proporção do que os réus de alto status econômico; e

Esta suposição se mostrou significativa nos três modelos de furto, mas não nos modelos de roubo. Se considerarmos a educação como uma proxy de status econômico, os réus com educação maior ou igual ao segundo grau têm uma chance menor de serem condenados do que os réus de outra escolaridade no tipo penal furto. No entanto, se compararmos com o tempo de sentença aplicado, os réus desta categoria que são condenados recebem penas maiores.

Provavelmente o que está ocorrendo é que os réus de maior status possuem condições de contratar melhores advogados, como argumentam alguns estudos, e, com isto, a chance deles escaparem de condenação nos casos menos graves é maior, só sendo condenados os casos mais graves, o que repercute na média de pena maior. No caso de roubo, um delito mais grave, este grupo não apresenta diferenças significativas na chance de condenação.

G) Os réus de baixo status econômico são condenados a penas mais duras que os réus de alto status.

No caso da variável meses de sentença aplicada ao furto, como falamos no item anterior, os réus recebem significativamente penas maiores, mas, quanto ao regime da pena, não há uma diferença significativa. No caso de roubo, os réus de maior educação têm chance maior de serem condenados a regimes menos gravosos, o que de certa forma vai no sentido de nossa explicação anterior, de que esta diferença provavelmente seja explicada pela capacidade de contratar um advogado melhor e com isto conseguir atenuantes processuais que permitam a sentença num regime menos gravoso.

A conclusão do primeiro problema que levantamos é a de que nenhuma das variáveis que os estudos de sentença feitos no Brasil apontam como importantes 
para explicar a pena são, de fato, significantes. A maior parte dos modelos se mostrou limitada para explicar alterações nas proporções de condenação e de regime mais gravoso.

Em todos os casos em que houve a introdução de variáveis processuais diretamente ligadas à variável dependente, estas se mostraram significantes e explicaram a maior parte do efeito do modelo. A suposição que fazemos é que se conseguíssemos agregar no banco de dados todas as variáveis processuais com efeito no processo, provavelmente chegaríamos a modelos com grande capacidade preditiva e que anulariam possíveis influências espúrias de outras variáveis que não estão ligadas diretamente à variação, mas que captam parte do efeito.

O que concluímos desta exposição é que a Justiça da comarca de São Paulo, na primeira instância, nos tipos analisados, está operando de acordo como é concebida pelo direito positivo, baseando seus julgamentos em questões processuais. Conseguimos algumas evidências neste sentido, contudo, por limitações do banco de dados, não foi possível coletar todas as variáveis processuais que permitiriam comprovar esta proposição alternativa aos estudos apresentados que creditam importância excessiva às variáveis sociais.

Não podemos comentar a parte destes estudos que tratam da discriminação por parte da polícia e dentro do sistema penal, pois nossos dados não permitem extrapolar a análise para fora do processo penal de conhecimento.

O segundo problema que abordamos segue no mesmo sentido da proposição anterior sobre o funcionamento da justiça penal. Ao analisarmos a proposição de recurso por parte do réu e do Ministério Público vemos que as variáveis que apresentam maior significância são as variáveis processuais. 
Há dois pontos importantes que influenciam na decisão de recorrer: a definição da tentativa e do regime da pena. Esta variável é consistente tanto no modelo de recurso do Ministério Público, quanto no modelo de recurso do réu, apresentando as maiores taxas de risco de recurso.

Isto é uma conclusão importante pois, mais uma vez, mostra que a divergência que ocorre nas decisões destes juízes está diretamente relacionada a aspectos processuais, principalmente à interpretação de dois aspectos do processo, a tentativa e a aplicação do regime fechado no caso de roubo.

Por fim, a posição ideológica do juiz frente ao direito penal parece, pelos resultados que encontramos, ter uma certa influência sobre a proporção de condenação e o regime da pena, sobretudo no caso de roubo. Novamente, a discussão que está por trás desta variação diz respeito a uma concepção de direito penal e não de uma ideologia política no sentido mais específico.

Cabe mais uma vez ressaltar que este último problema não pode ser generalizado, pois o número de casos, quando desagregado por varas, é pequeno, e as entrevistas foram feitas com um grupo reduzido de juízes. No entanto, os resultados encontrados parecem indicar que há uma certa influência deste posicionamento que deveria ser explorada em outros estudos.

O que podemos concluir dos três problemas analisados é que o poder judiciário, nesta comarca e instância que estudamos, está operando da forma como foi concebido pelo direito positivo, com apenas algumas distorções na interpretação de artigos específicos, mas que não foge do âmbito legal. As variações ideológicas dos juízes podem ter um impacto no processo, mas o padrão deste impacto está ligado a posições divergentes quanto à aplicação do direito penal, e não de padrões de decisão externos a este. 


\section{7 - Bibliografia}

ADORNO, S. F. (1989) "Violência Urbana e Justiça Criminal: o ponto de vista dos cientistas sociais" in Travessia: revista do migrante: CEM, São Paulo, maio-agosto, Ano 2, n. 4. p 17-20.

(1994) "Cidadania e Administração da Justiça Criminal" in DINIZ, E.; LOPES, J. S. L.; PRANDI, R. (org.) O Brasil no rastro da crise: Partidos, sindicatos, movimentos sociais, Estado e cidadania no curso dos anos 90: São Paulo, HUCITEC, p. 304-327.

(1995) "Discriminação racial e justiça criminal em São Paulo" in Novos Estudos: CEBRAP, São Paulo, nov. 95, vol 43. p 45-63.

(1998ª) "Consolidação democrática e políticas de segurança pública no Brasil: rupturas e continuidades" in Zaverucha, J. (org.) Democracia e instituições brasileiras no final do século XX: Recife, p.151-189.

$\left(1998^{b}\right)$ "O gerenciamento público da violência urbana: a justiça em ação" in São Paulo sem medo: um diagnóstico da violência urbana: São Paulo, Garamond, p.227-246.

(2002) "Crise no sistema de justiça criminal" in Ciência e Cultura: SBPC, ano $54, \mathrm{n} 1$, jul-set. p 50-51.

ARENDT, H. (1973) Crises da República, São Paulo, Perspectiva.

BAUM, L. (2005) The Puzzle of Judicial Behavior, Michigan, The University of Michigan Press, $6^{a}$ edição.

BECCARIA, M. (1959) Trad. Paulo M. de Oliveira; Dos delitos e das penas, São Paulo, Atenas Editora.

BOBBIO, N. (1993) Trad. Fernando P. Baptista e Ariani Bueno Sudatti; Teoria da Norma Jurídica, Bauru, São Paulo, EDIPRO, 2001. 
BONELLI, M. G.; (1995) "Condicionantes da competição professional no campo da justiça: a morfologia da magistratura" in SADEK, M. T. (org.) Uma introdução ao Estudo da Justiça, São Paulo, IDESP/Sumaré, p. 53-62.

BORDINI, E. B. T.; ADORNO, S. F. (1987) "Migração e criminalidade" in São Paulo em Perspectiva, Jul-Set, vol. 1, n 2, p. 36-38.

CARNeIRO, L. P. (1997) Direitos Civis e Cultura Política: um estudo comparativo sobre a consolidação democrática na América Latina; Rio de Janeiro, IUPERJ, Tese de doutorado.

CARVALHO, A. B. (2003) Magistratura e Direito Alternativo, Rio de Janeiro, Lúmen Juris, $6^{\mathrm{a}}$ edição.

CHIRICOS, T. G.; WALDO, G. P. (1975) "Socioeconomic status and criminal sentencing: an empirical assessment of a conflict proposition" in American Sociological Review; Volume 40, N. 6, Dezembro, p 753-772.

_ ; _ (1977) "Reply to Greenberg, Hopkins and Reasons" in American Sociological Review; Volume 42, N. 1, Fevereiro, p 181-185.

CINTRA, A. C. A.; GRINOVER, A. P.; DINAMARCO, C. R. (1993) Teoria Geral do Processo, São Paulo, Malheiros, 9a edição.

COHEN, L. E.; FELSON, M. (1979) "Social Change and Crime Rate Trends: A routine Activity Approach" in American Sociological Review; Volume 44, N. 4, Agosto, p 588-608.

D'URSO, L. F. B. (2002) Novos modelos penais: a legitimação das penas não privativas de direito. São Paulo, Faculdade de Direito da USP, Tese de doutorado.

DIXON, J. (1995) "The Organizational Context of Criminal Sentencing" in The A merican Journal of Sociology; Volume 100, N. 5, Março, p 1157-1198.

ELSTER, J. (1989) Nuts and Bolts, Cambridge, Cambridge University Press. 
FARIA, J. E. (1991) Justiça e Conflito: os juízes em face dos novos movimentos sociais, Sao Paulo, Editora Revista dos Tribunais.

GAUDET, F. E. (1938) "Individual Differences in the Sentencing Tendencies of Judges" in BODIN, N (Review) American Journal of Sociology; Volume 45, N. 4, Janeiro de 1940, p 622-623.

GIBBONS, D. C. (1969) "Crime and Punishment: A study in Social Attitudes" in Social Forces, Vol. 47, n. 4, pp. 391-397.

GRAMSCI, A. (1991) Maquiavel, a política e o Estado moderno, Rio de Janeiro, Editora Civilização Brasileira, $8^{a}$ edição.

GREENBERG, D. F. (1977) "Socioeconomic status and Criminal Sentencing: Is there an association?" in American Sociological Review; Volume 42, N. 1 , Fevereiro, p 174-176.

HABERMANS, J. (2003) Direito e Democracia: entre facticidade e validade. Rio de Janeiro, Tempo Brasileiro: vol: 1.

HOPKINS, A. (1977) "Is there a bias in Criminal Sentencing" in American Sociological Review; Volume 42, N. 1, Fevereiro, p 174-176.

IBCCRIM. (2005) Decisões Judiciais nos crimes de roubo em São Paulo: A lei, o direito e a ideologia: São Paulo, IBCCRIM / IDDD.

IKAWA, D. R. (2004) "Hart, Dworkin e Discricionaridade" in Lua Nova, n 61, pp 97113.

LEMGRUBER, J. (2001) "Novos modelos penais: mitos e fatos" in Revista Think Thank, Rio de Janeiro, Instituto Liberal do Rio de Janeiro.

LIMA, P. S.; TEIXEIRA, A; SINHORETTO, J. (2003) "Mulheres Negras : As mais punidas nos crimes de Roubo" in Boletim do Núcleo de Pesquisas do IBCCRIM, São Paulo, IBCCRIM, Ano 11, No 125, Abril de 2003, p. 1-4.

LUHMANN, N. (1983) Sociologia do Direito. Rio de Janeiro, Tempo Brasileiro: vol: 1. (1985) Sociologia do Direito. Rio de Janeiro, Tempo Brasileiro: vol: 2. 
KELSEN, H. (1998) Trad. João Batista Machado; Teoria Pura do Direito, São Paulo, Martins Fontes, $6^{a}$ edição.

MOISĖS, J. Á. (1995) Os brasileiros e a democracia: bases sócio-políticas da legitimidade democrática, São Paulo, Ática.

MYERS, M. A; TALARICO, S. M. (1987) "The Social Context of Criminal Sentencing" in ZINGRAFFO, M. T. (Review) Contemporany Sociology; Volume 18, N. 3, Maio 1989, p 400-401.

PASUKANIS, E. B. (1972) Trad. Soveral Martins; $A$ teoria geral do direito e o marxismo, Coimbra, Perspectiva Jurídica.

REASONS, C. E. (1977) "On methodology, theory and ideology" in American Sociological Review; Volume 42, N. 1, Fevereiro, p 174-176.

ROSS, A. (2000) Trad. Edson Bini; Direito e Justiça, Bauru, Edipro.

ROHDE, D. W.; SPAETH, H. J. (1976) Supreme Court Decision Making, São Francisco, W. H. Freeman.

SADEK, M. T. A. (org). (1995ª) O judiciário em debate. São Paulo: Sumaré.

$\left(1995^{b}\right)$ Uma introdução ao estudo da justiça. São Paulo: Sumaré

(1999) O sistema de justiça. São Paulo: Sumaré

SCHMITT, C. (1934ㄹ) Sobre os três tipos do pensamento jurídico in MACEDO JR., R. P. (2001) Carl Schmitt e a fundamentação do direito. São Paulo, Max Limonad: p. 161:217.

$\left(1934^{b}\right)$ O Führer protege o direito in MACEDO JR., R. P. (2001) Carl Schmitt e a fundamentação do direito. São Paulo, Max Limonad: p. 219:225.

(1932) A distinção amigo-inimigo, critério do político in $O$ conceito do pólítico. São Paulo, Vozes: p. 51:62. 
SEGAL, J. A.; SPAETH, H. J. (2002) The Supreme Court and the Attitudinal Model Revisited. Cambridge: Cambridge University Press.

SHECAIRA, S. S. (1991) Prestação de serviços à comunidade: alternativa a pena privativa de liberdade. São Paulo, Faculdade de Direito da USP, Dissertação de mestrado.

; CORRÊA JUNIOR, A. (2002) Teoria da Pena: Finalidades, Direito Positivo, Jurisprudência e outros estudos de Ciência Criminal. São Paulo, Editora Revista dos Tribunais.

SONGER, D. R.; SEGAL, J. A.; CAMERON, C. M. (1994) "The Hyerarchy of Justice: Testing a Principal-Agent Model of Supreme Court-Circuit Court Interations" in American Journal of Political Science; Volume 38, Issue 3, Agosto, p 673-696.

STTEFENSMEIER, D.; HERBERT, C. (1999) "Women and Men Policymakers: does the Judge Gender affect the sentencing of criminal defendant?" In Social Forces; Volume 77, N. 3, Março, p. 1163-1196.

; DEMUTH, S. (2000) "Ethnicity and sentencing Outcomes in U. S. Federal Courts: Who is punished more harshly?" In American Sociological Review Forces; Volume 65, N. 5, Outubro, p. 705-729.

TEIXEIRA, S. F. (1999) O Juiz: Seleção e Formação do Magistrado no Mundo Contemporâneo, Belo Horizonte, Del Rey, $1^{\text {a }}$ edição.

THOMSON, R. J.; ZINGRAFF, M. T. (1981) "Detecting Sentencing Disparity" in American Journal of Sociology; Volume 86, N. 4, Janeiro, p 869-880.

TOURINHO FILHO, F. C. $\left(2000^{a}\right)$ Processo Penal, São Paulo, Editora Saraiva, $22^{\mathrm{a}}$ edição, vol 1. $\left(2000^{b}\right)$ Processo Penal, São Paulo, Editora Saraiva, 22a edição, vol 2. 
VIANNA, L. W.; CARVALHO, M. A. R.; MELO, M. P. C.; BURGOS, M. B. (1997) Corpo e alma da magistratura brasileira, Rio de Janeiro, Renavam, $3^{\text {a }}$ edição.

WATANABE, K. (2001) "Perfil do réu nos delitos contra o patrimônio (furto e roubo)" in Revista Forense, Rio de Janeiro, v. 97, n. 356, p. 433-436, jul./ago. 2001.

WEBER, M. (1922) Economía y derecho in WINCKELMANN, J. (org.) (1997) Economia Y Sociedad. México, D. F., Fondo de Cultura Económica: $11^{\text {a }}$ reimpresión.

(1917) Parlamentarismo e governo numa Alemanha reconstruída in Tragtenberg, M. (1972) Weber. São Paulo, Abril Cultural: Coleção Pensadores: vol XXXVII

WOOD, S. L.; KEITH, L. C.; LANIER, D. N.; OGUNDELE, A. (1998) "'Acclimation Effects" for Supreme Courts Justices: A Cross-Validation, 1888-1940" in American Journal of Political Science; Volume 42, Issue 2, Abril, p 690697. 


\section{8 - Legislação}

Código judiciária do Estado de São Paulo - Decreto lei complementar n³/1969 com alterações posteriores.

Código penal - decreto lei 2848/1940 com alterações posteriores.

Código do processo penal - Decreto Lei 3.689/1941 com alterações posteriores. Constituição Federal da República Federativa do Brasil de 1988. 
ANEXO I - Questionário aplicado junto aos juízes

Vara: Data:

1- Nome:

2- Idade: 3- Estado Civil:

4- Escolaridade da Mãe:( ) primário ( ) $2^{\circ} \mathrm{grau} \mathrm{(} \mathrm{)} \mathrm{superior}$

5- Profissão da mãe:

6- Escolaridade do pai: ( ) primário $\quad$ ( ) $2^{\circ}$ grau ( ) superior

7- Profissão do pai:

8- Faculdade na qual se formou: 9- Ano:

10- Formado em outro curso superior: ( ) Não ( ) Sim. Qual?

11- Experiência profissional anterior
( ) Nenhuma
( ) Advocacia
( ) Defensoria
( ) Min. Público
( ) Outras.

12- Por quantos anos:

13- Tem parentes no meio jurídico (resposta múltipla)
( ) Nenhum
( ) Advocacia
( ) Defensoria
( ) Min. Público
( ) Outras.

14- Tem simpatia por partidos políticos: ( ) Não ( ) Sim. Qual?

15- Na escala política esquerda direita em que ponto você se posicionaria?
( ) Esquerda
( ) Centro Esquerda
( ) Centro
( ) Centro Direita
( ) Direita

16- Para as seguintes afirmações, numa escala de 0 a 10 , onde 0 significa discordar totalmente, e 10 significa concordar totalmente, qual o grau de concordância do Sr. (a) ?

A. O compromisso com a justiça social deve preponderar sobre a estrita aplicação da lei.

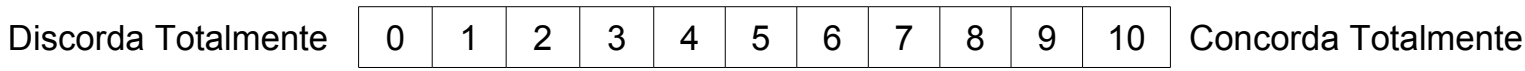

B. A aplicação da lei sempre beneficia os privilegiados.

\begin{tabular}{l|l|l|l|l|l|l|l|l|l|l|l|l|}
\hline Discorda Totalmente & 0 & 1 & 2 & 3 & 4 & 5 & 6 & 7 & 8 & 9 & 10 & Concorda Totalmente
\end{tabular}

C. $O$ direito positivo não permite o espírito crítico.

Discorda Totalmente \begin{tabular}{|l|l|l|l|l|l|l|l|l|l|l|}
0 & 1 & 2 & 3 & 4 & 5 & 6 & 7 & 8 & 9 & 10 \\
Concorda Totalmente
\end{tabular}

D. $\mathbf{O}$ judiciário deve desempenhar um papel ativo no sentido de reduzir as desigualdades sociais. \begin{tabular}{ll|l|l|l|l|l|l|l|l|l|l|l|} 
Discorda Totalmente & 0 & 1 & 2 & 3 & 4 & 5 & 6 & 7 & 8 & 9 & 10 & Concorda Totalmente
\end{tabular}

E. A idade penal deve ser reduzida para dezesseis anos.

\begin{tabular}{l|l|l|l|l|l|l|l|l|l|l|l|} 
Discorda Totalmente & 0 & 1 & 2 & 3 & 4 & 5 & 6 & 7 & 8 & 9 & 10 \\
Concorda Totalmente
\end{tabular}

F. Os tipos penais classificados como hediondos devem ser ampliados.

Discorda Totalmente \begin{tabular}{|l|l|l|l|l|l|l|l|l|l|l|}
0 & 1 & 2 & 3 & 4 & 5 & 6 & 7 & 8 & 9 & 10 \\
\hline
\end{tabular}

G. O juiz deve pautar suas decisões pelo princípio do direito penal mínimo.

Discorda Totalmente \begin{tabular}{|l|l|l|l|l|l|l|l|l|l|l|}
0 & 1 & 2 & 3 & 4 & 5 & 6 & 7 & 8 & 9 & 10 \\
\hline
\end{tabular}

H. O juiz deve aplicar preferencialmente as penas alternativas à privação de liberdade.

\begin{tabular}{l|l|l|l|l|l|l|l|l|l|l|l|l|}
\hline Discorda Totalmente & 0 & 1 & 2 & 3 & 4 & 5 & 6 & 7 & 8 & 9 & 10 & Concorda Totalmente
\end{tabular} 
